Florida International University FIU Digital Commons

\title{
Groundwater nutrient availability controls on nearshore benthic community structure in Biscayne Bay, Florida
}

Danielle Lara Mir-Gonzalez

Florida International University

DOI: $10.25148 /$ etd.FI15102791

Follow this and additional works at: https://digitalcommons.fiu.edu/etd

Part of the Biology Commons

\section{Recommended Citation}

Mir-Gonzalez, Danielle Lara, "Groundwater nutrient availability controls on nearshore benthic community structure in Biscayne Bay, Florida" (2007). FIU Electronic Theses and Dissertations. 3525.

https://digitalcommons.fiu.edu/etd/3525 
FLORIDA INTERNATIONAL UNIVERSITY

Miami, Florida

\section{GROUNDWATER NUTRIENT AVAILABILITY CONTROLS ON NEARSHORE BENTHIC COMMUNITY STRUCTURE IN BISCAYNE BAY, FLORIDA}

A thesis submitted in partial fulfillment of the

requirements for the degree of
MASTER OF SCIENCE
in
BIOLOGY
by

Danielle Lara Mir-Gonzalez 
To: Interim Dean Mark Szuchman

College of Arts and Sciences

This thesis, written by Danielle Lara Mir-Gonzalez, and entitled Groundwater Nutrient Availability Controls on Nearshore Benthic Community Structure in Biscayne Bay, Florida, having been approved in respect to style and intellectual content, is referred to you for judgment.

We have read this thesis and recommend that it be approved.

Joseph N. Boyer

John F. Meeder

Jennifer H. Richards

James W. Fourqurean, Major Professor

Date of Defense: May 23, 2007

The thesis of Danielle Lara Mir-Gonzalez is approved.

Interim Dean Mark Szuchman

College of Arts and Sciences

Dean George Walker

University Graduate School

Florida International University, 2007 


\section{DEDICATION}

I dedicate this thesis to my husband, J. Raul Gonzalez, for his patience, support and love throughout my masters program. To my daughter, Julie V. Gonzalez, who kept me inspired to finish. And to my mother, Victoria Tchoryk, who has recently gone blind and taught me to never give up. Thank you.

In loving memory of my grandfather, Delio E. Mir, Sr., who was always proud of me and did not live to see me finish. 


\section{ACKNOWLEDGMENTS}

I would like thank my graduate committee, Dr. Jim Fourqurean, Dr. John "Jack" Meeder, Dr. Jennifer Richards and especially Dr. Joseph Boyer for their guidance, support and patience with this project during the last few years. A big thank you to Ginny Cornett, Amy Renshaw, Matthew Rogers, Dottie Byron, Emily Kuhnlein, and Patrick Gibson along with the many members of the SERC Lab for assisting with the sixty field days required to complete this project. To Rafael Gonzales and FOC staff for having vehicles and boats well maintained and available. I wish to thank Pete Lorenzo, Pura Rodriquez and SERC Lab technicians for their assistance with sample processing. I want to thank Susan Dailey, Liza Merly, Amanda Dean, Leanne Rutten and George Meichel for their technical assistance. A thank you goes to Biscayne National Park and Southeast Environmental Research Center for allowing this project to take place. I would like to thank Dr. Ron Jones for sponsoring me as his student during the beginning of my masters program up until he left FIU. A special thanks goes to my family for their love, support, and always being there for me, especially my mother, husband and daughter who has given me the motivation to finish. 
ABSTRACT OF THE THESIS

GROUNDWATER NUTRIENT AVAILABILITY CONTROLS ON NEARSHORE BENTHIC COMMUNITY STRUCTURE IN BISCAYNE BAY, FLORIDA by

Danielle Lara Mir-Gonzalez

Florida International University, 2007

Miami, Florida

Professor James W. Fourqurean, Major Professor

Most studies have focused on nutrient inputs from rivers, atmosphere, and nonpoint runoff. One often overlooked source of nutrient loading is submarine groundwater discharge. For this reason, a 207 site survey and four transects were established to document spatial distribution of macrophytes, quantify potential groundwater discharge and associated nutrient concentrations, estimate water column nutrient concentrations, and relate nutrient availability to seagrass stoichiometry. A significant decline in Thalassia testudinum and an associated increase in Halodule wrightii were significantly correlated with decreased salinity and increased ammonium and total phosphorus concentrations from surface and groundwater. Total phosphorus loading from groundwater was estimated to be 2.55 metric tons $\mathrm{y}^{-1}$ in the Black Point area, almost half the phosphorus load to all of southern Biscayne Bay from the canals. These findings indicate that nutrients in groundwater are important in determining seagrass community structure and spatial distribution in the shallow waters of Biscayne Bay. 


\section{TABLE OF CONTENTS}

CHAPTER

I. INTRODUCTION

Groundwater Nutrient Availability Controls on Nearshore Benthic

Community Structure in Biscayne Bay, Florida 1

Overview 1

Importance and Theories Behind Community Structure ............................ 3

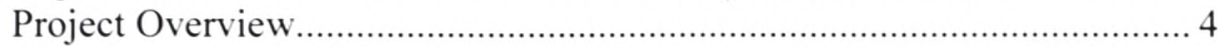

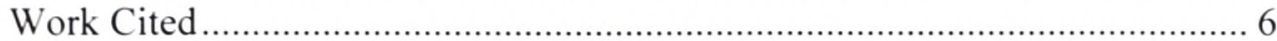

II. SPATIAL VARIATION OF NEARSHORE BENTHIC MACROPHYTE COMMUNITIES IN SOUTHWESTERN BISCA YNE BAY, FLORIDA ............ 8

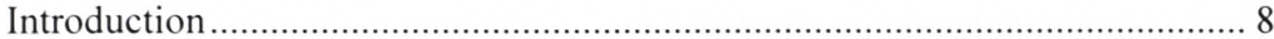

Dynamics of Southwestern Biscayne Bay ………….............................. 8

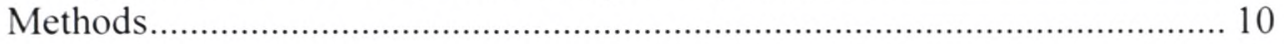

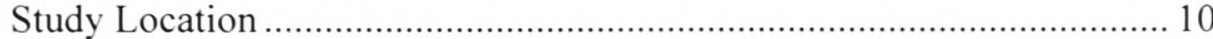

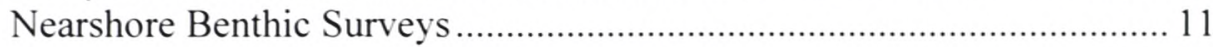

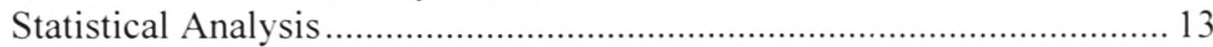

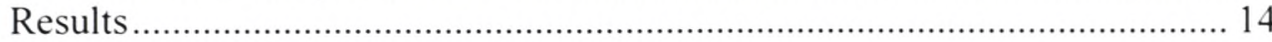

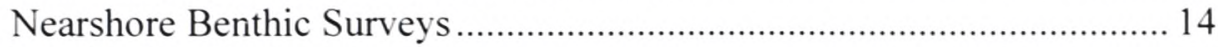

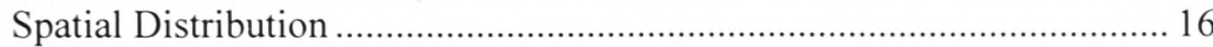

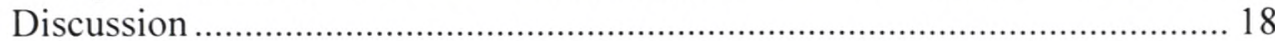

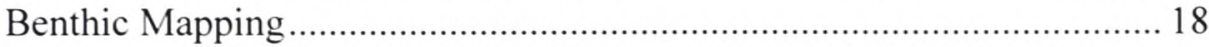

Possible Sources for Spatial Differences ………………......................... 19

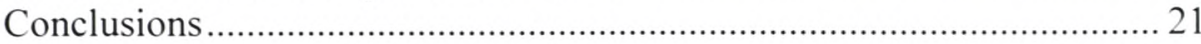

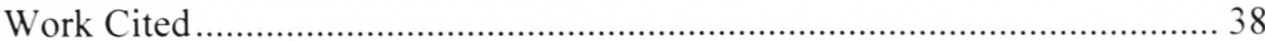

III. MEASURING THE RELATIONSHIP BETWEEN GROUNDWATER NUTRIENT LOADS AND BENTHIC MACROPHYTE COMMUNITIES....... 40

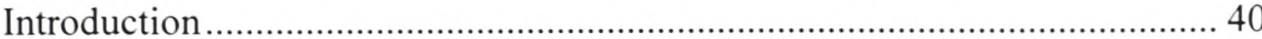

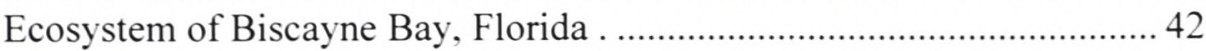

Factors that Potentially Effect Seagrass Communities ............................. 43

Groundwater as a Source of New Nutrients in Biscayne Bay .................. 44

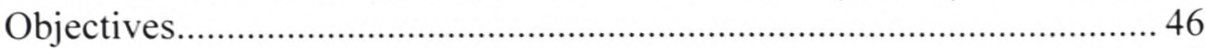

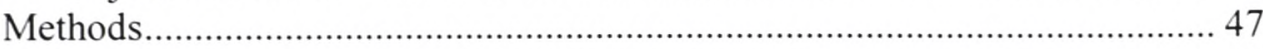

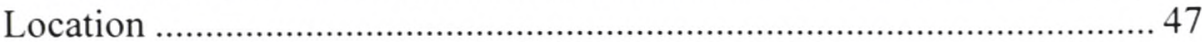

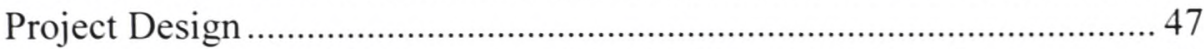

Benthic Community Structure and Physical Parameter Attributes ........... 48

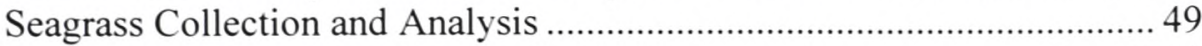

Water Collection and Analysis ............................................................. 50

Groundwater Collection and Analysis .................................................. 51

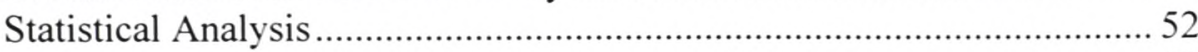

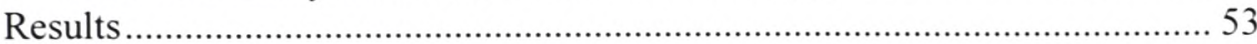

The Spatial Variation of Benthic Macrophytes......................................... 53 


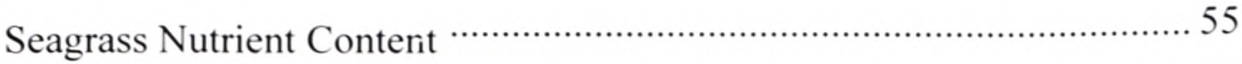

Water Quality ......................................................................... 55

Relationships Between Benthic Macrophytes and Nutrient Availability. 56

Groundwater Nutrient Concentrations and Discharge ............................ 57

Species Dominance in Relation to Groundwater Nutrients ................... 57

Potential Nutrient Loading into the Bay via Groundwater ...................... 59

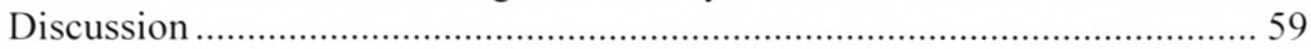

Spatial Variation of Benthic Macrophytes..................................... 59

Nutrient Availability and Effects on Benthic Macrophyte Communities. 60

Other Contributing Environmental Factors........................................... 61

Using Seepage Meters as a Proxy for Groundwater Discharge ............... 61

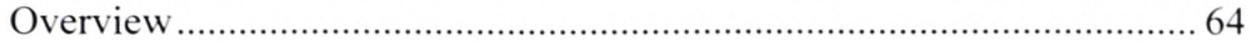

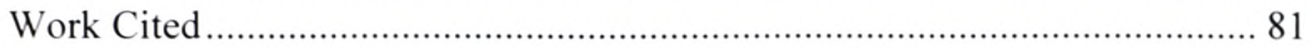

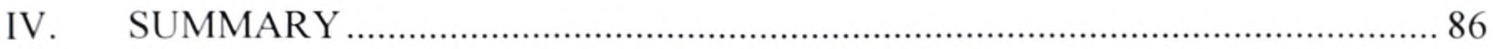

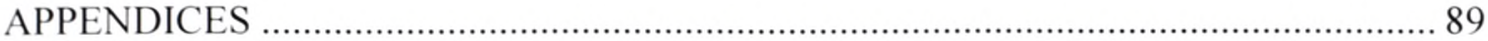


FIGURE

\section{LIST OF FIGURES}

Figure 1.1. Relative species dominance along a gradient of nutrient availability........ 5

Figure 1.2. The Biscayne Bay study area located along the western shoreline of Biscayne National Park. Nearshore study areas extended $1 \mathrm{~km}$ from

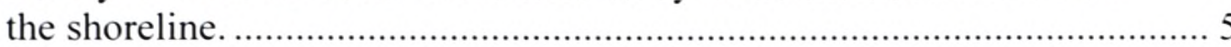

Figure 2.1. Location of study area in the southwestern portion of Biscayne Bay,

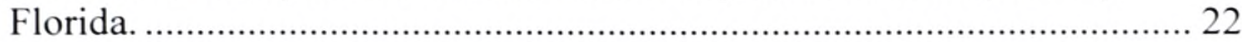

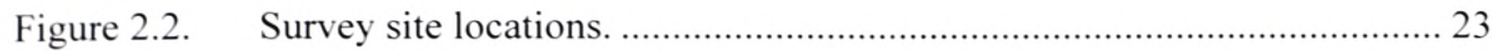

Figure 2.3a. Locations of site groupings - the four study locations ............................. 25

Figure 2.3b. Locations of site groupings - the three distance locations ....................... 26

Figures $2.4(\mathrm{a}-1)$. Interpolated distributions of nearshore benthic survey taxa groups (seagrasses total, Thalassia, Halodule, Ruppia, calcareous green algae, Penicillus sp., green algae, Batophora sp., Chara sp. red algae, and brown algae), and physical parameters (water depth, sediment type, and sediment depth) for the entire study area. ........................................ 26

Figure 2.5. Mean seagrass density among site location groups. ............................... 34

Figure 2.6. Mean macroalgae groups density (Braun-Blanket score) for taxa that were significantly different among site location groups........................... 34

Figure 2.7. Box-and-whisker plot of Halodule wrightii among the study areas......... 35

Figure 2.8. Box-and-whisker plot of Thalassia testudinum among the study areas.... 35

Figure 2.9. Box-and-whisker plot of Chara sp. among the study areas..................... 35

Figure 2.10. Box-and-whisker plots of two red algae genera density (Polysiphonia sp. and Acanthophora sp.) among study areas........................................ 36

Figure 2.11. Box-and-whisker plots of Thalassia testudinum and Halodule wrightii

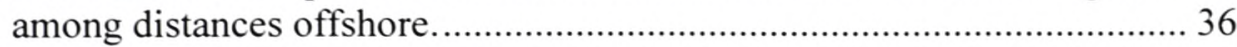

Figure 2.12. Box-and-whisker plots of salinity among distances offshore .................. 36

Figure 2.13. Box-and-whisker of green algae total density (Batophora sp., Cheatomorpha sp., Cladophora sp.) and Batophora sp. density (dominate species) among distances offshore. 


\section{LIST OF TABLES}

TABLE

PAGE

Table 2.1. Braun Blanquet scores for recording the abundance of benthic taxa and substrate type

Table 2.2. Frequency, abundance and density calculations for each species from the raw observations of benthic cover in each quadrat at each site.

Table 2.3. Benthic taxa used in the nearshore benthic community composition survey. A summary of taxa with the number and percentage of sites where each taxon was present and the maximum and minimum Braun Blanquet density scores for each taxa.

Table 3.1. Summary of taxa distributions, including the total number and percentage of sites (20) during the six events where each taxon was present. Presence/ absence data for each study area and the maximum and minimum Braun-Blanquet density found for each transect are listed. Asterisks indicate taxa presence within a transect.

Table 3.2a. Summary statistics of transect surface water and seagrass tissue nutrient data for Turkey Point and Mowry Canal area. (Summary continued in Table 3.3b)

Table 3.2b. Summary statistics of water and seagrass tissue nutrient data for Fender and Black Point area (Summary continued from Table 3.3a) 72

Table 3.3. Spearman's Correlation Matrix with correlation coefficients (above shaded diagonal) and $\mathrm{p}$-values for substrate, plant density, $\mathrm{H}$. wrightii $\mathrm{C}: \mathrm{N}: \mathrm{P}$. Based on the mean of all sampling sites $(\mathrm{n}=20)$. Bold face above $\mathrm{p}<0.05$.

Table 3.4. Summary statistics of groundwater nutrient concentrations and loads for the four study areas.

Table 3.5. Spearman's Correlation Matrix with correlation coefficients (above shaded diagonal) and p-values for mean substrate type, plant density, surface water quality and groundwater variables. Bold face above $\mathrm{p}<0.05$. Based on groundwater sites only $(\mathrm{n}=12)$.

Table 3.6. Groundwater nutrient load for the entire study area in tons $\mathrm{yr}^{-1}$ within the first $350 \mathrm{~m}$ offshore. 
Figure 2.14. Mean water depth (m) and dissolved oxygen for each study area.

Figure 3.1. Location of study area in the southwestern portion of Biscayne Bay,

Florida

Figure 3.2. Location of transects that represent the Turkey Point, Mowry Canal,

Fender Point and Back Point Vicinities.

Figure 3.3. Example of a seepage meter; (a) actual meter in field and (b)

schematic figure of seepage meter.

Figure 3.4. Box-and-whisker plot of Halodule wrightii showing 10 percentile. 68

Figure 3.5. Box-and-whisker plot of Ruppia maritima and Chara sp. among study regions.

Figure 3.6. Box-and-whisker plot of Batophora sp. among study regions. 69

Figure 3.7. Box-and-whisker plot of Penicillus sp. among study regions. 69

Figure 3.8. Mean macrophyte densities with distance offshore for entire area 70

Figure 3.9. Macrophyte site means of sampling events, with distance offshore; (a) Turkey Point, (b) Mowry Canal, (c) Fender Point and (d) Black Point.... 70

Figure 3.10. Box-and-whisker plot of Halodule wrightii; (a) \% P and (b) C: P among regions. 72

Figure 3.11. Halodule wrightii transect mean N: P ratio with distance offshore. 73

Figure 3.12. Box-and-whisker plot of surface water salinity among regions. 73

Figure 3.13. Box-and-whisker plot of groundwater salinity among study regions 76

Figure 3.14. Box-and-whisker plot of groundwater flow rates among study regions... 76

Figure 3.15. Mean groundwater flow rates $\left(\mathrm{l} \mathrm{m}^{-2} \mathrm{~d}^{-1}\right)$ with distance $(\mathrm{m})$ offshore. 76

Figure 3.16. Groundwater discharge rates in time for each transect (a-Tur, b-Mow, c-Fen, and d- Bla).

Figure 3.17. Groundwater total nitrogen and total organic carbon concentrations $(\mu \mathrm{M})$ with distance $(\mathrm{m})$ offshore 78

Figure 3.18. Groundwater loads (tons $\mathrm{yr}^{-1}$ ) with for each region. 80 


\section{INTRODUCTION}

Groundwater Nutrient Availability Controls on Nearshore Benthic Community Structure in Biscayne Bay, Florida

Overview

Changes in the quality, quantity, and timing of freshwater runoff in nearshore waters have been credited to human population growth in costal areas. Despite concerns about effects caused by anthropogenic impacts on the structure and function of nearshore benthic communities, there is a lack of general baseline data in these areas. Nearshore benthic communities have often been ignored, although they are closest to potential anthropogenic influences and most likely to show signs caused by disturbances. Nutrient and light availability are considered two of the primary physical factors that limit seagrass distribution (Dennison and Alberte 1985, Short 1987). Secondary factors such as changes in salinity, temperature, currents and sediment accumulation within an area, can also influence the composition of species within a community. Increased nutrient enrichment can change water quality, eventually leading to eutrophication. When eutrophic conditions occur, seagrasses and slow-growing macroalgae are replaced by fast-growing macroalgae and phytoplankton with phytoplankton eventually dominating through competition Figure 1.1 (Duarte 1995, Fourqurean and Rutten 2003).

Many studies have focused on anthropogenic nutrient inputs from the atmosphere, rivers, and non-point runoff (e.g. storm water). One often-overlooked source of nutrient loading is from groundwater upwelling or seepage. Along many coasts, submarine groundwater discharge is close to shore (Valiela et al. 1980). The effects of groundwater 
on benthic vegetation are not well understood in shallow estuarine areas and can have a great impact on overall water quality. It has been estimated that submarine groundwater discharge contributes three to five times as much nitrogen to an estuary as does surface water (Johannes 1980). Misinterpretations of ecological data relating to benthic zonation and productivity can occur by neglecting to incorporate groundwater discharge. In some areas, anthropogenic activities have increased groundwater nutrients and loading, which may lead to problems in the nearshore environment (Lapointe et al. 1990). The distribution of Thalassia testudinum and other benthic macrophytes have been linked to groundwater discharge in Biscayne Bay (Kohout and Kolipinski 1967).

The focus of this investigation is southwestern Biscayne Bay, between Black Point and Turkey Point (Figure 1.2) in Biscayne National Park. Chapter 1, the "Introduction", gives a basic overview community structure dynamics and the objective of this project. Chapter 2, "Spatial variation of nearshore benthic macrophyte communities in southwestern Biscayne Bay, Florida," is a descriptive study that maps nearshore $(<1 \mathrm{~km})$ benthic macrophyte community distribution. This section documents benthic macrophytes and explores the relationships of spatial variation and environmental factors. Chapter 3, "Measuring the relationship between groundwater nutrient loads and benthic macrophyte communities," asks whether spatial distributions of macrophytes are affected by groundwater nutrient availability. Transects were used to document and explore relationships between benthic macrophyte community (species) distribution, seagrass nutrient content, surface water and groundwater nutrient concentrations and load. The findings of this two-part study are briefly summarized in chapter 4 , the "Summary". 


\section{Importance and Theories Behind Community Structure}

An ecological community is an assemblage of species that co-occur in space and time. The relationship between pattern and process has long been the focus of plant community studies (Watt 1947). Species diversity and abundance are key components of the structure of an ecological community. Particular species can have strong effects on ecosystem process by directly mediating energy and material fluxes or by changing abiotic conditions of the environment, which in turn may regulate the rates of these processes (Hooper and Vitousek 1997, Tilman et al. 1997). Hooper and Vitousek (1997) asserted that functional characteristics of the component species are likely to be as important as species diversity in maintaining critical ecosystem processes. Community structure is an indicator, and presumably affected by the environmental factor of interest (e.g. nutrient loadings), and may be the only feasible measurement in a particular environment (Philippi et al. 1998).

Species diversity is important to community structure and has been shown to have a positive correlation with productivity (Connell and Orias 1964). Through both monitoring studies and experiments, species diversity patterns in a population have been attributed to variation in the intensity of competition (Paine 1966). Disturbances are a controlling mechanism in ecological systems; it has been suggested that the continuous addition of nutrients may act as a perturbation to marine macrophytes, releasing nutrient limitation and the competition for other resources (e.g. light). Some think that diversity should be added along with species composition, disturbance, nutrient supply, and climate as a major controller of population, ecosystem dynamics and structure (Tilman 1999). 


\section{Project Overview}

Biscayne Bay is a shallow subtropical lagoonal estuary situated as a topographic basin resting between the Atlantic Coastal Ridge and offshore reef and barrier island system. The bay is located on the southeastern coast of Florida at about $25^{\circ} 45^{\prime} \mathrm{N}$ and $80^{\circ} 15^{\prime} \mathrm{W}$. The presence of two landfills (old and new) and the large agricultural centers in southeast Miami pose a threat to groundwater and surface water quality. Several preexisting studies exist suggesting the landfills have already degraded water quality (Jones 1994, Meeder \& Boyer 2001). Groundwater seepage and canal discharge are two major sources that add new nutrients to the nearshore environment of western Biscayne Bay, Florida. Groundwater nutrient loading can be especially important in karstic limestone environments because of the high porosity of such systems. The effects of groundwater on benthic macrophyte communities are not well understood in nearshore areas although groundwater has a great potential to impact overall water quality. Biscayne Bay does not have the same wealth of published background information on benthic community structure as the nearby estuary, Florida Bay, making it difficult for coastal researchers to focus their conservation efforts in the appropriate direction. Therefore, this study was initiated to document and determine if groundwater nutrient loading contributes to the variation found within the nearshore benthic macrophyte composition of southwestern Biscayne Bay, Florida. 


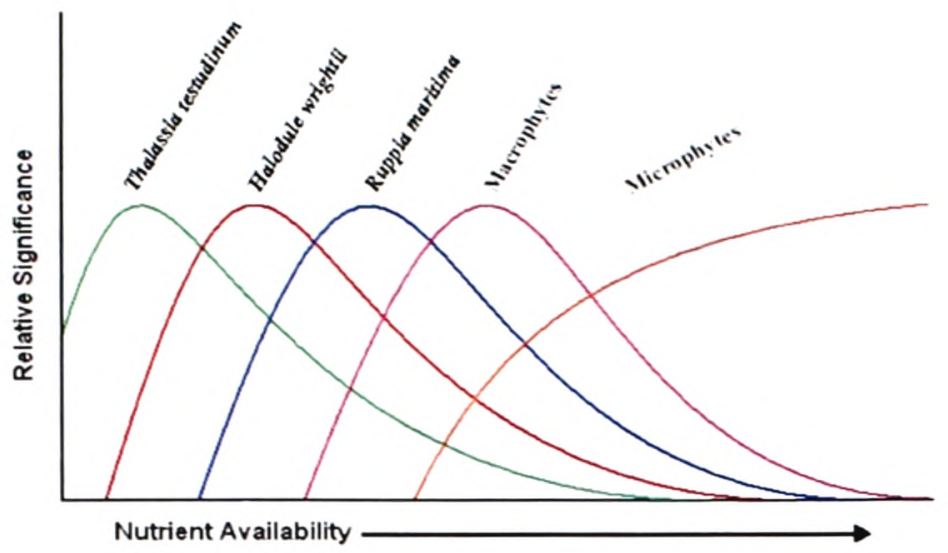

Figure 1.1. Relative species dominance along a gradient of nutrient availability. This conceptual model relates the relationship between nutrient availability and the relative dominance of different types of primary producers of south Florida (adapted from Fourqurean and Rutten 2003).

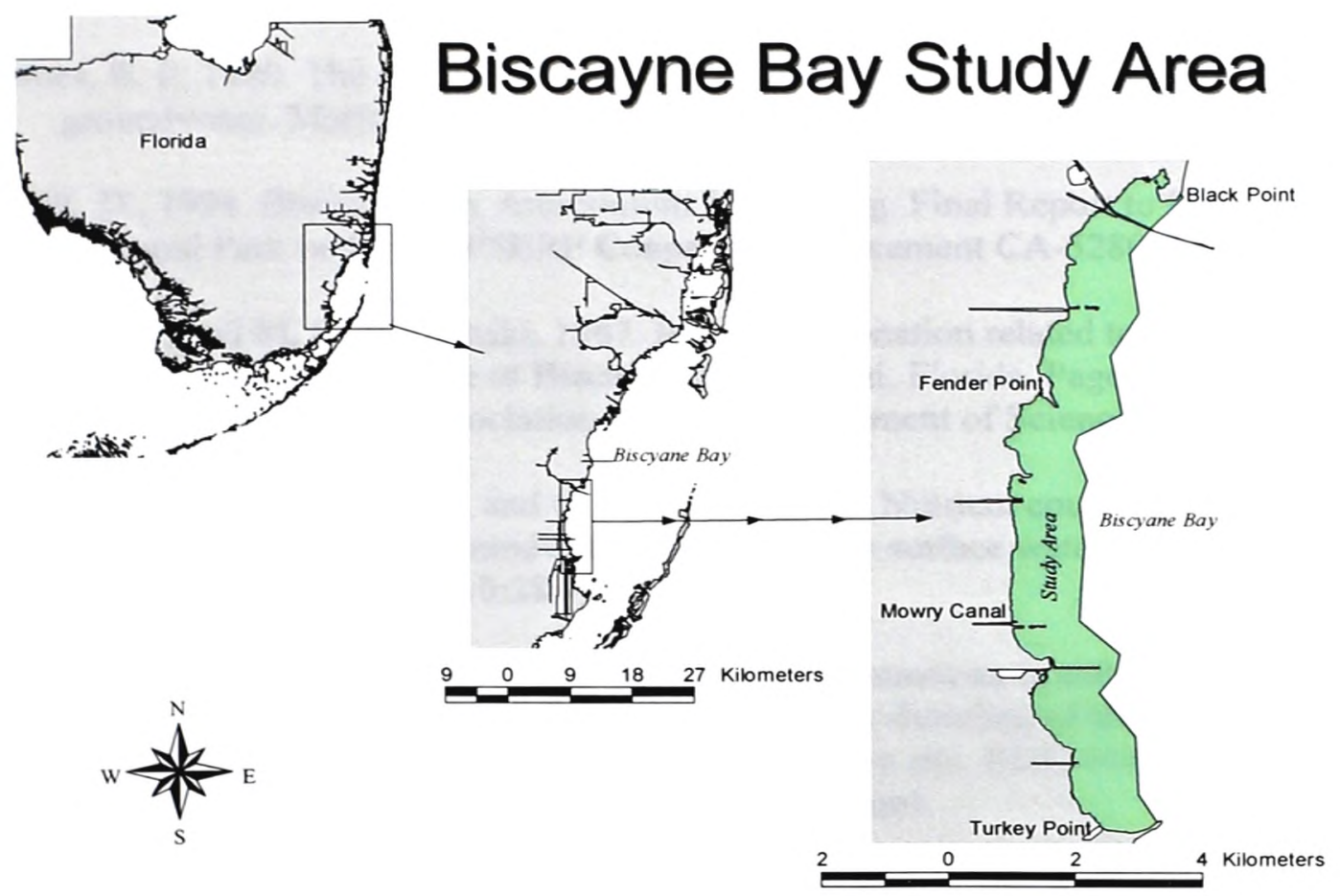

Figure 1.2. The Biscayne Bay study area located along the western shoreline of Biscayne National Park. Nearshore study areas extended $1 \mathrm{~km}$ from the shoreline. 


\section{Work Cited}

Connell, J. H., and E. Orias. 1964. The ecological regulation of species diversity. The American Naturalist 98:399-441.

Dennison, W. C., and R. S. Alberte. 1985. Role of daily light period in the depth distribution of Zostera marina (eelgrass). Marine Ecology Progress Series 25:5161 .

Duarte, C. M. 1995. Submerged aquatic vegetation in relation to different nutrient regimes. Ophelia 41:87-112.

Fourqurean, J. W., and L. M. Rutten. 2003. Competing goals of spatial and temporal resolution: monitoring seagrass communities on the regional scale. Pages 257-288 in D. E. Busch and J. C. Trexler, editors. Monitoring Ecosystems:

Interdisciplinary Applications for Evaluation Ecoregional Initiatives. Island Press, Washington.

Hooper, D. U., and P. M. Vitousek. 1997. The effects of plant composition and diversity on ecosystem processes. Science 277:1302-1305.

Johannes, R. E. 1980. The ecological significance of the submarine discharge of groundwater. Marine Ecology Progress Series 3:365-373.

Jones, R. D., 1994. Biscayne Bay Ammonium Monitoring. Final Report to Biscayne National Park under NPS/SERP Cooperative Agreement CA-5280-8-8007.

Kohout, F. A., and M. C. Kolipinski. 1967. Biological zonation related to groundwater discharge along the shore of Biscayne Bay, Miami, Florida. Pages 488-499 in Estuaries: American Association for the Advancement of Science.

Lapointe, B. E., J. D. O'Connell, and G. S. Garrett. 1990. Nutrient couplings between onsite disposal systems, groundwater, and nearshore surface waters of the Florida Keys. Biogeochemistry 10:289-307.

Meeder, J., and J. N. Boyer. 2001. Total ammonia concentrations in soil, sediments, surface water, and groundwater along the western shoreline of Biscayne Bay with the focus on Black Point and a reference mangrove site. BISC-N-011.000, Final Report to National Park Service, SERC, FIU, Miami.

Paine, R. T. 1966. Food web complexity and species diversity. The American Naturalist 100:67-75.

Philippi, T. E., P. M. Dixon, and B. E. Taylor. 1998. Detecting trends in species composition. Ecological Applications 8:300-308. 
Short, F. T. 1987. Effects of sediment nutrients on seagrasses: literature review and mesocosm experiment. Aquatic botany 27:41-57.

Tilman, D. 1999. The ecological consequences of changes in biodiversity: A search for general principles. Ecology 80:1455-1474.

Tilman, D., J. Knops, D. Wedin, P. Reich, M. Ritchie, and E. Siemann. 1997. The influence of functional diversity and composition on ecosystem processes. Science 277:13001302.

Watt, A. S. 1947. Pattern and process in the plant community. Journal of Ecology 35:122. 


\section{SPATIAL VARIATION OF NEARSHORE BENTHIC MACROPHYTE COMMUNITIES IN SOUTHWESTERN BISCAYNE BAY, FLORIDA}

\section{Introduction}

Seagrass communities (benthic macrophyte communities) are composed of numerous types of primary producers, which include seagrasses (rooted angiosperms), macroalgae (rhizophytic and/ or drift forms) and epiphytic algal species. Major changes in water quality due to increased nutrient enrichment and the timing of freshwater flow can affect the structure and function of benthic macrophyte communities. Nutrient enrichment can lead to a progressive replacement of seagrasses and slow-growing macroalgae by fast-growing macroalgae and phytoplankton with phytoplankton eventually dominating (Figure 1.1). As the City of Miami continues to grow, seagrass communities are most likely to exhibit signs of anthropogenic disturbance, especially within the nearshore environment of Biscayne Bay.

\section{Dynamics of Southwestern Biscayne Bay}

Biscayne Bay is located adjacent to a large agricultural and urban center undergoing major human population expansion. Anthropogenic impacts have lead to increased nutrient loading via canal flow and groundwater discharge into the Bay. The construction of a complex network of drainage canals and pumping stations to divert freshwater flow from Lake Okeechobee and the Everglades for flood control, agricultural and urban settings are the largest impact to the South Florida landscape. As a result, Biscayne Bay no longer receives freshwater as diffusive sheet flow, but rather as, a point 
source from canal discharges. The Surface Water Improvement and Management Plan (SWIM) for Biscayne Bay separated the bay into three distinct regions: North, Central and South (Alleman et al. 1995). South Bay (Figure 2.1), the focus of this study, receives flows from two distinct interconnected drainage systems known as the South Dade coastal drainage area and the conveyance system drainage area (Alleman et al. 1995 ).

Nearshore areas of South Bay are more affected by nutrient loadings than sites offshore (Caccia and Boyer 2005). Black Point, located in the northern part of South Bay, has high ammonium $\left(\mathrm{NH}_{4}{ }^{+}\right)$concentrations along the shoreline (Meeder and Boyer 2001). The nearshore area of the Bay is the most degraded in terms of water quality with high concentrations of nutrients (Caccia and Boyer 2005). There are four canals in southwestern Biscayne Bay, which carries nutrient rich freshwater. Mowry Canal caries water from the large agricultural basins; Black Creek and Princeton Canal are by Black Point landfill and sewage treatment plant while Military Canal carries water from the Homestead Military Base.

Both salinity fluctuations and nutrient loading from canals have been shown to affect benthic community structure in the receiving waters (Meeder and Boyer 2001). Much of the published literature dealing with nearshore seagrass communities in southwestern Biscayne Bay dates from the 1960's and 1970's. Historical projects have documented a thin band of Halodule wrightii dominance along the shore and high abundance in the Black Point area, with Thalassia testudinum most abundant offshore and near Turkey Point (Roessler et al. 1973, Thorhaug 1976). One investigation found $T$. testudinum present north of Black Point but absent around Princeton Canal also known as Moody Canal (Between Black Point and Fender Point) (Szmant 1987). A recent study 
showed that Black Point had a high surface water ammonium $\left(\mathrm{NH}_{4}{ }^{+}\right)$concentrations along the shoreline (Meeder and Boyer 2001). These high $\mathrm{NH}_{4}{ }^{+}$concentrations were found with a lower abundance of T. testudinum. These findings are confounded with salinity increases and fluctuations over time (Meeder and Boyer 2001). North of Black Point (Cutler Canal), Kohout and Kolipinski (1967) observed a transition from $H$. wrightii nearshore to T. testudinum offshore, and suggested the species pattern was due to groundwater seepage close to shore. Therefore, Thalassia testudinum and other benthic macrophyte distribution have been linked to groundwater discharges in Biscayne Bay (Kohout and Kolipinski 1967, Meeder et al. 1997)

This investigation was initiated to provide a comprehensive, spatially relevant description of nearshore benthic macrophytes and to attempt to explain possible environmental controls of the structure affecting benthic communities in the southwestern region of Biscayne Bay.

\section{Methods}

\section{Study Location}

This project sampled along the western shoreline of Biscayne Bay in Biscayne National Park (Figure 2.1), between Black Point (location of a unconfined landfill) and Turkey Point (area with a nuclear power plant). Currently, freshwater enters the Bay via canals as point source. Canal waters have poor water quality in that they contain high levels of urban and agricultural waste. These alterations have ultimately changed the timing and delivery of when and how freshwater enters the bay (Alleman, et al, 1995). The southern of the Bay is wider than most areas further north that has historically 
received less freshwater, since it is far from the watershed and the low relief. Parallel to the coastline about 0.6 to 1 kilometer $(\mathrm{km})$ inland is the L-31E Levee and Canal to prevent saltwater encroachment and reduce impact from storm tides; this canal essentially eliminated any remaining freshwater sheet flow to the Bay.

\section{Nearshore Benthic Surveys}

An intensive snapshot survey was conducted to document the distribution and composition of current nearshore benthic communities of southwestern Biscayne Bay. Within an $11.5 \mathrm{~km}$ stretch along the coast, benthic macrophyte community composition was surveyed at 207 sites located within $1 \mathrm{~km}$ from shore. Before sites were chosen, the relevant scales of spatial variation in community structure were determined by findings in current literature and reports (Meeder et al. 1997, Byrne 1999). Site locations were determined using a Random Tessellation Stratified (RTS) Design to ensure independence of sample locations and even coverage within the chosen sampling area. These preselected random coordinates were located in the field using a global positioning device (GPS) following a method similar to that used in the Environmental Monitoring and Assessment Program (EMAP). Two grids of hexagon cells with 1 site per $0.1 \mathrm{~km}^{2}$ were overlain in order to get approximately 2 sites per $0.1 \mathrm{~km}^{2}$ projected over the study area. Of the original 249 sites projected over the study area, data were collected for 207 sites (Figure 2.2) during the months of March, April and May 2002. The remaining 41 sites were not surveyed due to location and/ or time constraints.

At each site, seagrass and non-epiphytic macroalgae species were assessed in situ using a modified Braun-Blanquet quadrat method, which assigns a unitless score to 
represent percent cover (Table 2.1) (Braun-Blanquet 1972, Fourqurean et al. 2001). Taxa were assigned a score between 0 and 5 recorded from ten $0.25 \mathrm{~m}^{2}$ quadrats haphazardly, tossing quadrat with eyes closed, within $10 \mathrm{~m}$ of the GPS coordinate (Fourqurean et al. 2002). The average score for each taxon was computed for the 10 quadrats for each site to yield a Braun-Blanquet density, abundance or frequency estimate. Estimates are as follows: A score of 0 indicated that a species was absent; 0.1 indicated a solitary stem covering less than $5 \%$ of the quadrat; 0.5 indicated few stems covered less than $5 \%$ of the quadrat; 1 indicated numerous stems covering less than $5 \%$ of the quadrat; 2 indicated 5 $25 \%$ cover; 3 indicated $25-50 \%$ cover, 4 indicated $50-75 \%$ cover; and 5 indicated 75 $100 \%$ cover (Table 2.1). The Braun-Blanquet scores were used to calculate density $\left(\mathbf{D}_{\mathbf{a}}\right)$, abundance $\left(\mathbf{A}_{\mathbf{a}}\right)$, and frequency $\left(\mathbf{F}_{\mathbf{a}}\right)$ for each taxon (a) at each site as shown on Table 2.2.

Water depth was estimated in feet ( $\mathrm{ft}$.) at the boat. Substrate/ sediment type was assessed qualitatively and included the categories of fine mud, sandy mud, muddy sand, coarse sand, shell hash, rubble, and rock (Table 2.1). Sediment depth, ranging from zero $\mathrm{cm}$ to $>50 \mathrm{~cm}$, was measured using a $75 \mathrm{~cm}$ long thin rod marked in $5 \mathrm{~cm}$ increments. The rod was pushed perpendicularly into the sediment until it contacted solid rock or reached a depth greater than $50 \mathrm{~cm}$. Salinity, dissolved oxygen (DO) and temperature were recorded at each site using a Hydrolab ${ }^{\circledR}$ Mini-sonde (Hach Environmental, Colorado) 


\section{Statistical Analysis}

The spatial structure of the data was interactively explored using ArcView ${ }^{\circledR}$ Spatial Analyst with Nieuwland Kriging Interpolator 3.2 extension, which assumes that distance or direction between sample points reflect spatial correlation that can explain variation in the surface. Universal Kriging with linear drift algorithms were used for all surface interpolations in this survey since it assumes that an overriding trend exists in the data which can be modeled. The interpolative method of Kriging was used to produce separate weighting parameters for each interpolation point and taking spatial covariance in to effect to produce nearshore community distributions.

I analyzed variation in structure in the South Bay macrophyte community by dividing the area into 4 north-south regions (Figure 2.3a) and 3 nearshore-offshore regions (Figure 2.3b) to determine significant differences among study locations and distance offshore. Locations for "study areas" were divided into four "groups" labeled as Black Point (Bla) area $(n=38)$, Fender Point $(F e n)$ area $(n=40)$, Mowry Canal (Mow) area $(n=75)$ and Turkey Point (Tur) area $(n=54)$. The assemblage of the locations groups were determined by known canal and groundwater discharge estimates along with the geologic setting of the area. The three "distance offshore groups" were created and are described as nearshore (D1) zone $(0-350 \mathrm{~m}, \mathrm{n}=70)$, central (D2) zone $(350-700 \mathrm{~m}$, $n=72)$ and offshore (D3) zone (700- $1000 \mathrm{~m}, \mathrm{n}=65)$. Distance sections were based on previous finding on community zonations and groundwater upwelling (Szmant 1987, Meeder et al. 1997, Byrne 1999). Benthic and physical data of each group were reported as box-and-whisker plots. A box-and-whisker plot shows the median, range, and data distribution and is a convenient way of graphically showing the five-number summary. 
The center horizontal line of the box is the median of the data, the top and bottom of the box are the $25^{\text {th }}$ and $75^{\text {th }}$ percentiles (quartiles), and the ends of the whiskers are the $10^{\text {th }}$ and $90^{\text {th }}$ percentiles. The dots $(\bullet)$ above and below the whisker ends are the $5^{\text {th }}$ and $95^{\text {th }}$ percentile values.

All response variables failed to meet the requirements of normality required by normal parametric statistics (Kolmogorov-Smirnov and Shapiro-Wilk test for Normality, all $\mathrm{p}<0.05$ ). Therefore among "group" differences were assessed using the nonparametric Wilcoxon Ranked Sign test (comparable to the t-test) and among group by the nonparametric Kruskal-Wallis test (comparable to ANOVA) with significance of $p \leq 0.05$. Groups that were significantly different were then tested using Mann-Whitney U test, in order to determine how the groups differed by comparing medians of all paired cluster groups among all physical site parameters and/ or taxa at a level of $\mathrm{p}<0.05$ (2-tailed test).

\section{$\underline{\text { Results }}$}

Nearshore Benthic Surveys

Seagrasses and green algae were the most abundant macrophyte components of the nearshore benthic communities (Table 2.3). Seagrasses were present at all survey sites with densities ranging between 5.0 and 0.1 . Within the seagrass group, Ruppia maritima was present at $7 \%$ of the sites, Thalassia testudinum (81\%) and Halodule wrightii $(60 \%)$. Thalassia testudinum was absent from Black Point area except north of the Goulds Canal while densest offshore about $400 \mathrm{~m}$ from Fender Point south. Halodule wrightii, on the contrary, had the greatest density close to shore and at Black Point 
(Figure 2.4a). Ruppia maritima was sparsely found from the central to north part of the study area (Figure $2.4 \mathrm{~b})$.

Calcareous green algae were present at nearly $88 \%$ of all survey sites with a maximum density of 2.85 and a minimum density of 0.01 (Table 2.3). Calcareous green algae were almost evenly distributed throughout the study area except in the Black Point area (Figure 2.4c). The genera Penicillus and Acetabularia were among the taxa most frequently encountered; they were present at over $68 \%$ and $55 \%$ of survey sites, respectively. The genera Halimeda and Udotea were not as abundant (present at 17\% and $6 \%$ of sites, respectively), and found only in the southern region around Tur. Solitary individuals of genera Ripocephalus were encountered at one survey site at Tur.

Non-calcareous green algae were present at nearly $90 \%$ of the survey sites, with a maximum density of 4.1 and a minimum density of 0.05 (Table 2.3 ), with the highest densities between 300-400 m from shore (Figure 2.4d). The genus Batophora was present at nearly $85 \%$ (maximum density of 3.5 ) of the survey sites, while the genus Cladophora was present at $21 \%$ of sites (maximum density of 2.5 ). Batophora was most dominant nearshore of Mowry Canal and north of Fender Point with a small area offshore of Turkey Point (Figure 2.4d). The genus Avrainvillea was found at one site. The genus Chara was localized at Black Point with a small area south of Fender Point (Figure 2.4e), while Anadyomene stellata was found in the southern region; each occurred at approximately $17 \%$ of the sites.

Red algae were present at over $90 \%$ of the survey sites, with a maximum density of 3.6 and a minimum density of 0.05 (Table 2.3 ). Red algal densities were highest between Mowry Canal and Turkey Point, with some areas offshore in the northern 
section of the study area (Figure 2.4e). The genera Acanthophora and Polysiphonia accounted for the majority of red algae encountered throughout the survey ( $74 \%$ and $67 \%$, respectively).

Brown algae were only represented by the genus Sargassum and were present at $7 \%$ of the sites (Table 2.3 ). The maximum density of brown algae did not exceed 0.35 at any site and was only found in the Turkey Point vicinity (Figure 2.4f). Sponges and stony corals (Siderastrea radians) were mainly found near Turkey Point. Both sponges and stony corals were found at $3 \%$ of the sites with a maximum density of 0.2 at offshore sites (Table 2.3).

\section{Spatial Distribution}

Among the four study locations Halodule wrightii and green algae increased northward towards Black Point (Bla) while Thalassia testudinum and calcareous green algae densities increased southward towards Turkey Point (Tur) (Figures $2.5 \& 2.6$ ). Halodule wrightii density was substantially highest for $\mathrm{Bla}(\mathrm{Z}$ for Bla*Fen $=-4.034$, $\mathrm{p}<0.001 ; \mathrm{Z}$ for $\mathrm{Bla} *$ Mow $=-4.797, \mathrm{p}<0.001, \mathrm{Bla} *$ Tur $=-6.920, \mathrm{p}<0.001)($ Figure 2.7) while T. testudinum densities were lowest $(\mathrm{Z}$ for Bla*Fen $=-4.034, \mathrm{p}<0.001 ; \mathrm{Z}$ for Bla*Mow $=-4.797 ; \mathrm{Z}$ for $\mathrm{p}<0.001 ; \mathrm{Bla} *$ Tur $=-6.920, \mathrm{p}<0.001)($ Figure 2.8). Mowry Canal area had the highest density of $T$. testudinum. The presence of $R$. maritima and Chara sp. was significantly higher in Bla than the other zones $\left(\mathrm{Z}_{\text {(Ruppia) }}\right.$ for Bla*Fen $=$ $1.964, \mathrm{p}<0.05 ; \mathrm{Z}_{\text {(Ruppia) }}$ for Bla*Mow $=-2.00, \mathrm{p}<0.05 ; \mathrm{Z}_{\text {(Ruppia) }}$ for Bla*Tur $=-6.920, \mathrm{p}<$ $0.001)$ (Figure 2.5); $\left(Z_{\text {(Chara) }}\right.$ for Bla*Fen $=-4.360, p<0.001 ; Z_{\text {(Chara) }}$ for $B l a * M o w=-$ 5.052, $\mathrm{p}<0.001 ; \mathrm{Z}_{\text {(Chara) }}$ for $\mathrm{Bla} * \mathrm{Tur}=-4.993, \mathrm{p}<0.001$ ) (Figure 2.9). Chara $\mathrm{sp}$. was 
found exclusively at Black Point. Fender and Turkey Point had the highest red algae densities (Figure 2.6). Polysiphonia sp. had highest densities at Fender Point while Acanthophora sp. was dominate at Turkey Point with a significance of $\mathrm{p}<0.001$ (Figure 2.10). Turkey Point was the only area with Halimeda sp., Udotea sp. and Sargassium sp. present.

Of the three "distance offshore groups", the furthest offshore group (D3) had a significantly higher of Thalassia testudinum density along with increased water depth. Halodule wrightii significantly decreased offshore $\left(\mathrm{Z}\right.$ for $\mathrm{D} 1{ }^{*} \mathrm{D} 2=-5.145, \mathrm{p}<0.001 ; \mathrm{Z}$ for $\mathrm{D} 1 * \mathrm{D} 3=-6.888, \mathrm{p}<0.001, \mathrm{D} 2 * \mathrm{D} 3=-2.553, \mathrm{p}<0.05$, while $T$. testudinum increased offshore $(Z$ for $\mathrm{D} 1 * \mathrm{D} 2=-2.498, \mathrm{p}<0.05 ; \mathrm{Z}$ for $\mathrm{D} 1 * \mathrm{D} 3=-4.849, \mathrm{p}<0.001, \mathrm{D} 2 * \mathrm{D} 3=-$ 2.671, $\mathrm{p}<0.05$ ) (Figure 2.11). The nearshore distance (D1) of $0-350 \mathrm{~m}$ offshore had significantly lower salinity values (Figure 2.12 ). This area also had the highest densities of H. wrightii, R. maritima and Chara sp. and deepest sediment. The offshore distance (D3= $750-1000 \mathrm{~m}$ ) green algae density (Batophora $\mathrm{sp}$. dominated) was found to be significantly lowest compared to the other distance groups $\left(\mathrm{Z}_{(\text {(Batophora) }}\right.$ for $\mathrm{D} 3 * \mathrm{D} 1=$ $3.595, \mathrm{p}<0.001 ; \mathrm{Z}_{\text {(Batophora) }}$ for $\mathrm{D} 3 * \mathrm{D} 2=-2.254, \mathrm{p}<0.05$ ) (Figure 2.13). Water depth significantly increased offshore $(Z$ for $D 1 * D 2=-4.589, \mathrm{p}<0.001 ; Z$ for $\mathrm{D} 1 * \mathrm{D} 3=-6.593$, $\mathrm{p}<0.001 ; \mathrm{Z}$ for $\mathrm{D} 2 * \mathrm{D} 3=-1.987, \mathrm{p}<0.05)$.

Overall greatest densities for T. testudinum and Acanthophora sp. along with increased salinity, water depth and sandy type sediments were found offshore (D3, $750 \mathrm{~m}$ to $1 \mathrm{~km})$ where Batophora sp. was in low abundance. Brackish water tolerant species $(H$. wrightii, R. maritima and Chara sp.) were significantly denser within 0-350 m offshore 
(nearshore D1) compared to the other distances. Sediment was the shallowest along with significantly high Halimeda sp. abundances within the 350-750 m (D2) distance range.

Environmental variables such as salinity values and water depth were highest in the southern half of the study area where sediments were sandy. Along with these physical parameters, calcareous green totals (primarily Penicillus sp.), T. testudinum, and Acanthophora sp. were most abundant. The northern section of the study area had an increase in Batophora sp. and H. wrightii while sediment type was muddier in texture. Dissolved oxygen (DO) was significantly elevated at Black Point (Figure 2.14).

\section{Discussion}

Benthic Mapping

A distinct spatial pattern among the benthic macrophyte communities was found within the study area. The entire area examined is relatively small, approximately $11 \mathrm{~km}$ from north to south and $1 \mathrm{~km}$ offshore. Marine species dominated at Turkey Point (Tur) and offshore where salinities and water depth were greatest. The entire northern area, Black Point, was dominated by brackish water tolerant species within the first $300 \mathrm{~m}$ offshore. Three species of seagrass (Thalassia testudinum offshore and south, Halodule wrightii inshore \& Ruppia maritima north nearshore) were found throughout the study region. 


\section{Possible Sources for Spatial Differences}

Thalassia testudinum was dominant seagrass species found in southwestern

Biscayne Bay except at Black Point or along the coast. Historical reports have also found an absence of T. testudinum at Black Point (Roessler et al. 1973, Thorhaug 1976, Szmant 1987, Meeder and Boyer 2001). Thalassia testudinum tends to grow in oligotrophic waters that do not have salinity fluctuations (Fourqurean et al. 2003, Lirman and Cropper 2003). The Black Point area contained predominantly brackish water macrophyte species (Chara sp. and Ruppia maritima) and had the lowest salinity values, indicating that there is a freshwater source. Szmant (1987) noted there was stratification of water column due to salinity in spite of the shallow depths ( $2 \mathrm{~m})$ around the Black Point area. During the mapping (this section) of this project only surface salinity values were recorded, therefore, stratification in the water column could not be determined. Months after mapping community structure, stratified salinities were observed during the sampling efforts found in the next chapter (Chapter 3 ) since both bottom and surface salinity were recorded. Freshwater entering the area with increased nitrogen (especially ammonium) can have a negative affect on T. testudinum seedlings (Kahn and Durako 2006). A recent report documented high surface water ammonium that $\left(\mathrm{NH}_{4}{ }^{+}\right)$ concentrations along the shoreline and corresponding lower abundance of T. testudinum near Black Point (Meeder and Boyer 2001). The Szmant (1987) study did not find a correlation between nutrient concentrations and freshwater seepage from the sediments, but did find lower water column salinity, higher nutrient concentrations, and dark water color (brown tannins) in the area between Black Creek (Black Point) and Princeton 
Canal. Ammonium and nitrate concentrations at Black Pont did decrease in the offshore direction (Szmant 1987).

Canal water discharge (CD) and submarine groundwater discharge (SDG) can add freshwater along with elevated nutrient concentrations into an estuary. Black Point and Mowry Canal have the highest canal discharge for this study area (Alleman et al. 1995, Lietz 1999). Salinity fluctuations and nutrient loading from canals have been shown to affect benthic community structure in the receiving waters (Meeder and Boyer 2001). The lack of canal discharge at Turkey Point might explain why it was the only area to have the marine genera such as Halimeda, Udotea, Ripocephalus, Avrainvillea, Anadyomene, and Sargassium, along with the stony coral Siderastrea radians.

The importance of SGD and its influences on surface water salinities in the study area is established (Kohout and Kolipinski 1967, Meeder et al. 1997, Byrne 1999). Submarine groundwater discharge can pose a threat to an estuary by decreasing surface salinity or change the timing of the salinity cycle. In addition, SGD often has a higher nitrogen load than does that of surface water (Johannes 1980). Groundwater volume discharge into Biscayne Bay is much less than canals, but the concentrations of nutrients are greater (Byrne 1999). However, little is known about SGD and its effects in this area. Meeder et al (1997) found that the groundwater $\mathrm{NH}_{4}{ }^{+}$concentrations at Black Point were the highest in the bay and decreased by nearly $50 \%$ in both northward and southward directions. Thalassia testudinum was also not abundant in areas receiving groundwater discharge. Salinity significantly increases in the offshore direction. Its been reported that along many coasts, submarine groundwater discharge is close to shore (Valiela et al. 1980 ) and decreases rapidly with distance from shore (Bokuniewicz and Pavlik 1990, 
Meeder et al. 1997, Byrne 1999). Near Mowry Canal, the nearshore community composition report suggested SGD decreased with distance from shore, and that the first few hundred meters are dominated by Halodule wrightii then Penicillus sp. and Batophora sp., with T. testudinum predominant at $800 \mathrm{~m}$ (Meeder et al. 1997). This study had similar results and suggests that groundwater discharge may be causing the lower salinities nearshore and at Black Point. Freshwater in these areas may be significant due to a shallow water column that coincides in these areas.

\section{Conclusions}

The presence of two unconfined landfills at Black Point has created conditions of high nutrient loading, a major concern for managers and researchers. Run-off and groundwater nutrients may be significant in determining community structure type in the coastal regions of the Bay. If submarine groundwater discharge is present, it may be more important than canal discharge in structuring the benthic macrophyte communities due to high concentrations of nutrients along with low salinities. This investigation's goal was to provide observational data in order to describe nearshore benthic macrophyte spatial distributions in southwestern Biscayne Bay. Additionally, an evaluation of the SAV spatial variation related to nutrient availability and groundwater nutrient loads in the nearshore environment of southwestern Biscayne Bay was conducted as a later part of this investigation (Chapter 3). Benthic macrophyte communities nearshore could be significantly influenced by canal discharge and / or groundwater upwelling. Studying the relationships between macrophytes and groundwater may give us a better insight on the processes involved, and better help managers. 


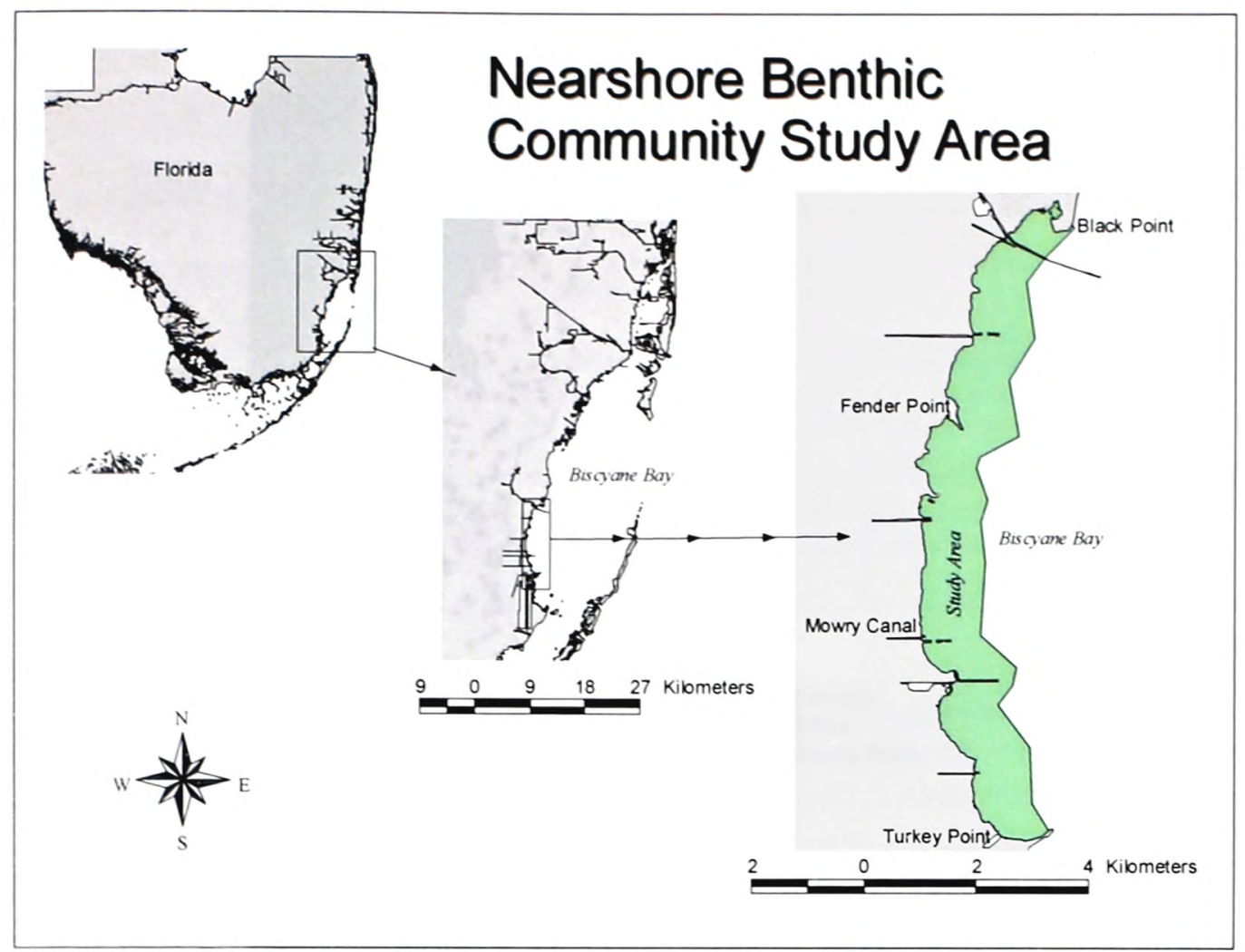

Figure 2.1. Location of study area in the southwestern portion of Biscayne Bay, Florida. 


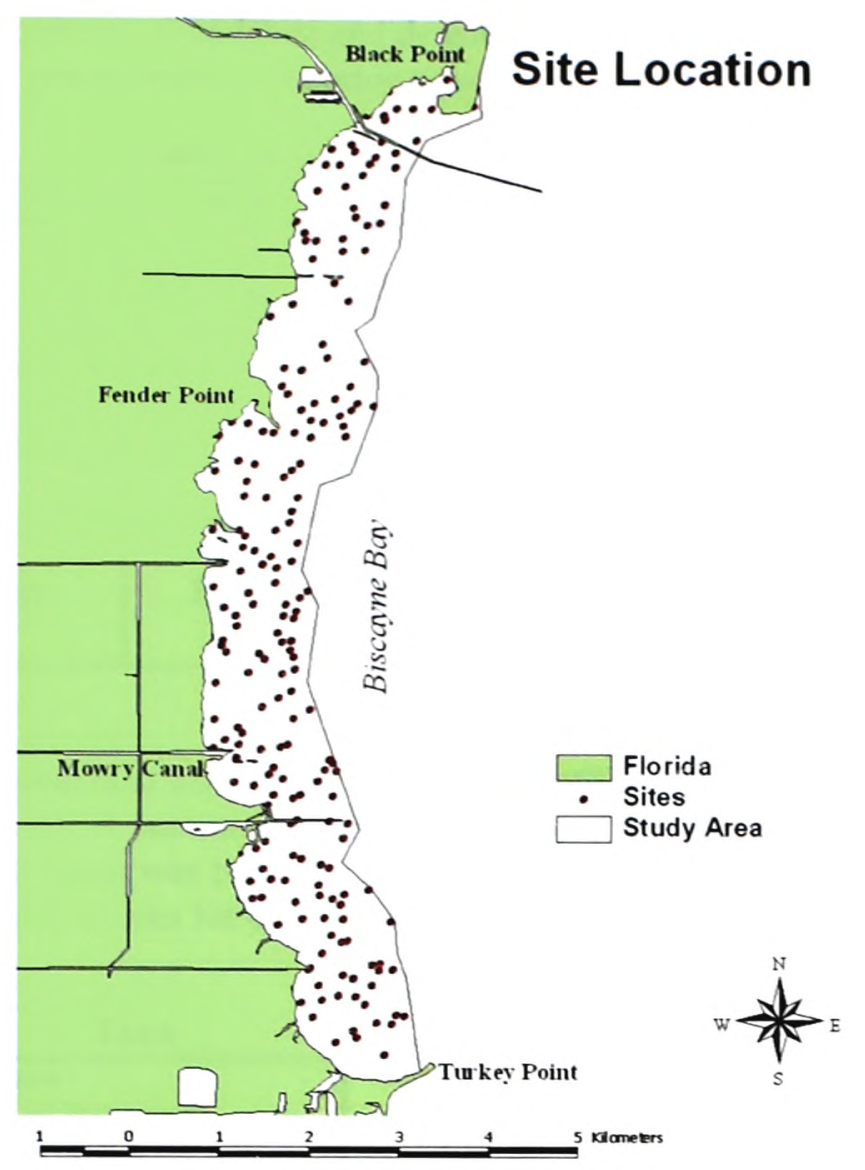

Figure 2.2. Survey site locations.

Table 2.1. Braun Blanquet scores for recording the abundance of benthic taxa and substrate type.

\section{Braun Blanquet Scores}

\begin{tabular}{|c|c|c|c|}
\hline Score & Substrate Type & Score & Taxa Percent Cover \\
\hline 1 & Fine-Mud & 0.0 & Absent \\
2 & Sandy-Mud & 0.1 & Solitary, $<5 \%$ \\
2 & Sandy-Mud Shell & 0.5 & Sparse, $<5 \%$ \\
3 & Muddy-Sand & 1.0 & Many, $<5 \%$ \\
3 & Muddy-Sand Shell & 2.0 & $5 \%-25 \%$ \\
4 & Sand & 3.0 & $25 \%-50 \%$ \\
5 & Course Sand & 4.0 & $50 \%-75 \%$ \\
6 & Halimeda Hash & 5.0 & $75 \%-100 \%$ \\
\hline
\end{tabular}


Table 2.2. Frequency, abundance and density calculations for each species from the raw observations of benthic cover in each quadrat at each site.

Calculation of Braun Blanquet Scores

\begin{tabular}{|l|l|l|}
\hline Calculation & Formula & Discription \\
\hline Abundance & $\mathbf{D}_{\mathbf{a}}=\left(\mathbf{F}_{\mathbf{a}}\right)\left(\mathbf{A}_{\mathbf{a}}\right)$ & $\begin{array}{l}\text { where } \mathrm{Fa} \text { and } \mathrm{Aa} \text { are as described above, with a score } \\
\text { that can range between } 0 \text { and } 5 .\end{array}$ \\
\hline Frequency & $\mathbf{F}_{\mathbf{a}}=\mathbf{N}_{\mathbf{a}} / \mathbf{n}$ & $\begin{array}{l}\text { where the sum of Sa is the Braun-Blanquet score, } \\
\text { between } 0 \text { and } 5, \text { for taxon a found within a quadrat } \\
\text { observed at a site and Na is the number of quadrats at a } \\
\text { site in which taxon a was present. }\end{array}$ \\
\hline & $\begin{array}{l}\text { where Na as described above and } \mathbf{n} \text { is the number of } \\
\text { quadrats observed at a site, and the score is between } 0 \\
\text { and } 1 .\end{array}$ \\
\hline
\end{tabular}

Table 2.3. Benthic taxa used in the nearshore benthic community composition survey. A summary of taxa with the number and percentage of sites where each taxon was present and the maximum and minimum Braun Blanquet density scores for each taxa.

\begin{tabular}{|c|c|c|c|c|}
\hline \multirow{2}{*}{ Taxa } & \multicolumn{2}{|c|}{ Presence at Sites } & \multicolumn{2}{|c|}{ Density Score } \\
\hline & \# of sites & $\%$ of sites & Max & Min \\
\hline Seagrass & 207 & 100.0 & 5.00 & 0.10 \\
\hline Thalassia testudinum & 168 & 81.2 & 5.00 & 0.01 \\
\hline Halodule wrightii & 125 & 60.4 & 4.90 & 0.05 \\
\hline Ruppia maritima & 15 & 7.2 & 2.60 & 0.05 \\
\hline Calcareous Green Algae & 182 & 87.9 & 2.85 & 0.01 \\
\hline Genus Halimeda & 35 & 16.9 & 0.51 & 0.02 \\
\hline Genus Penicillus & 141 & 68.1 & 2.80 & 0.01 \\
\hline Genus Ripocephalus & 1 & 0.5 & 0.05 & 0.05 \\
\hline Udotea flabellum & 13 & 6.3 & 0.67 & 0.01 \\
\hline Acetabulania crenulata & 113 & 54.6 & 2.10 & 0.01 \\
\hline Green Algae & 186 & 89.9 & 4.10 & 0.05 \\
\hline Batophora oerstedia & 174 & 84.1 & 3.50 & 0.02 \\
\hline Anadyomene stellata & 36 & 17.4 & 0.70 & 0.05 \\
\hline Genus Avrainvillea & 1 & 0.5 & 0.05 & 0.05 \\
\hline Genus Chara & 35 & 16.9 & 2.70 & 0.05 \\
\hline Genus Chaetomorpha & 19 & 9.2 & 0.50 & 0.05 \\
\hline Genus Cladophora & 44 & 21.3 & 2.50 & 0.05 \\
\hline Red Algae & 192 & 92.8 & 3.60 & 0.05 \\
\hline Genus Laurencia & 5 & 2.4 & 0.40 & 0.05 \\
\hline Genus Acanthophora & 152 & 73.4 & 3.00 & 0.05 \\
\hline Genus Chondria & 2 & 1.0 & 0.10 & 0.05 \\
\hline Genus Polysiphonia & 137 & 66.4 & 3.00 & 0.05 \\
\hline Brown Algae & 14 & 6.8 & 0.35 & 0.01 \\
\hline Genus Sargassum & 14 & 6.8 & 0.35 & 0.01 \\
\hline Stony Corals & 6 & 2.9 & 0.20 & 0.01 \\
\hline Siderastrea radians & 6 & 2.9 & 0.20 & 0.01 \\
\hline Sponges & 6 & 2.9 & 0.10 & 0.10 \\
\hline
\end{tabular}




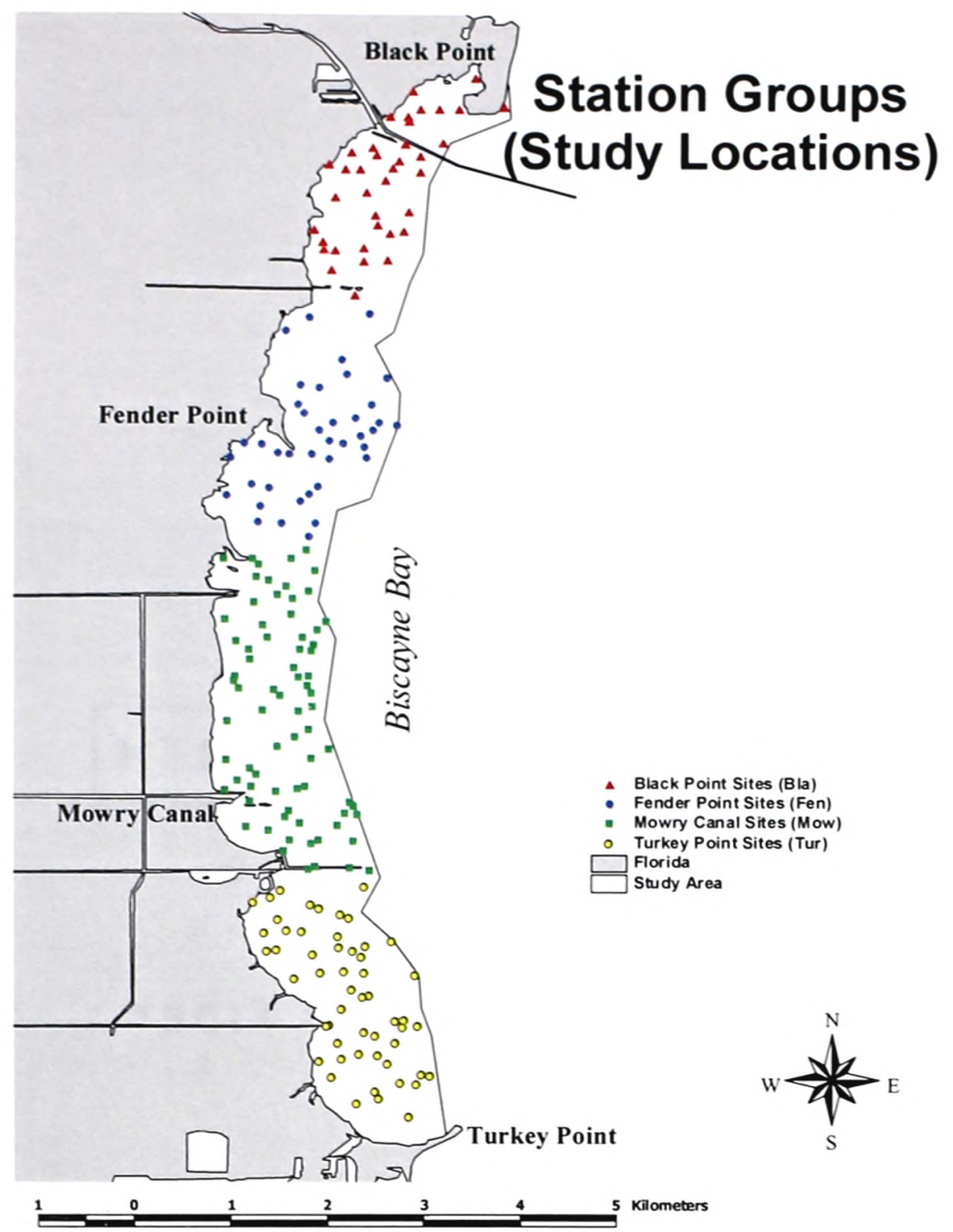

Figure 2.3a. Locations of site groupings - the four study locations (Groupings continued on Figure 2.3b). 


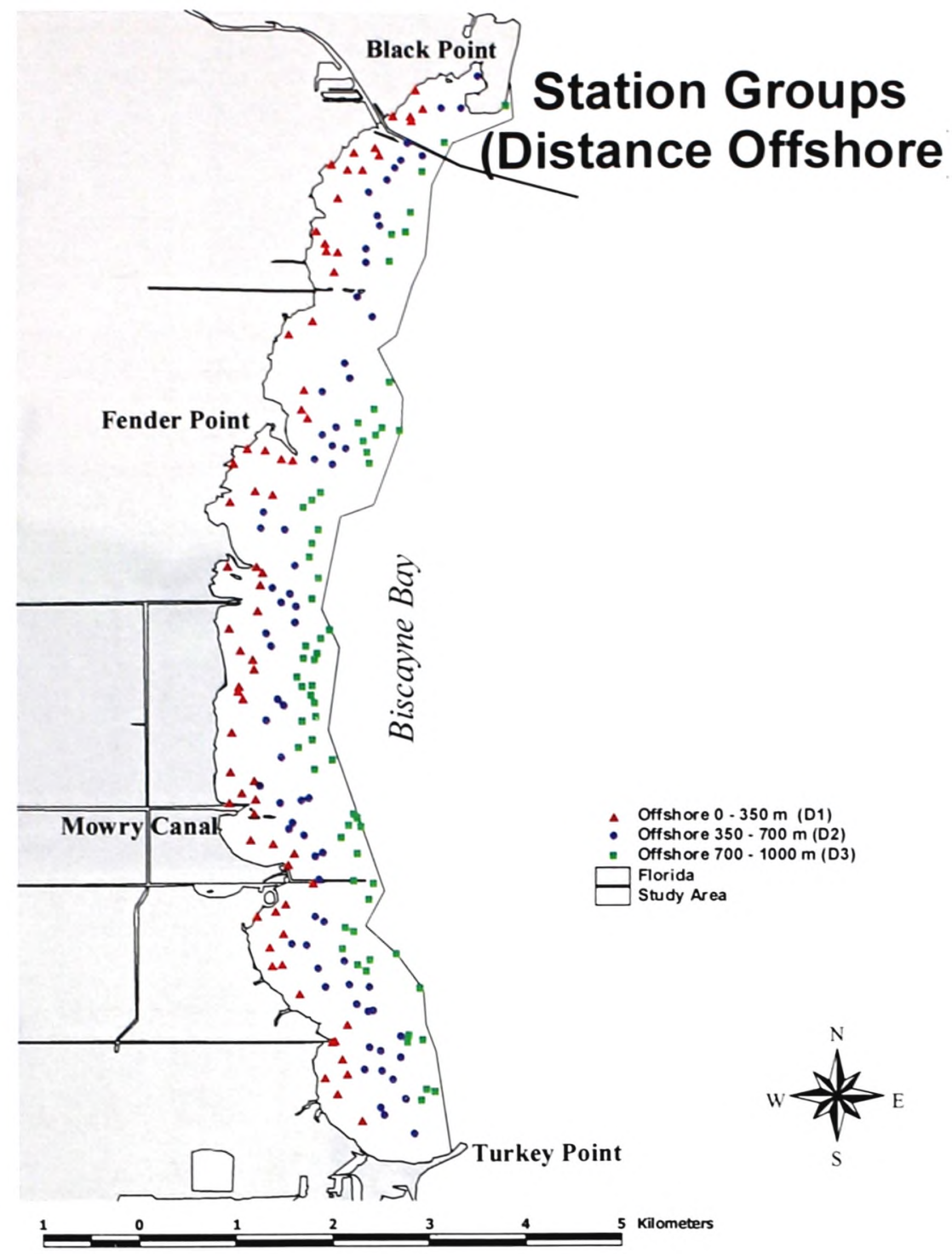

Figure 2.3b. Locations of site groupings - the three distance locations (Groupings continued from Figure 2.3a).

Figures $2.4(\mathrm{a}-1)$. Interpolated distributions of nearshore benthic survey taxa groups (seagrasses total, Thalassia, Halodule, Ruppia, calcareous green algae, Penicillus sp., green algae, Batophora sp., Chara sp. red algae, and brown algae), and physical parameters (water depth, sediment type, and sediment depth) for the entire study area. 


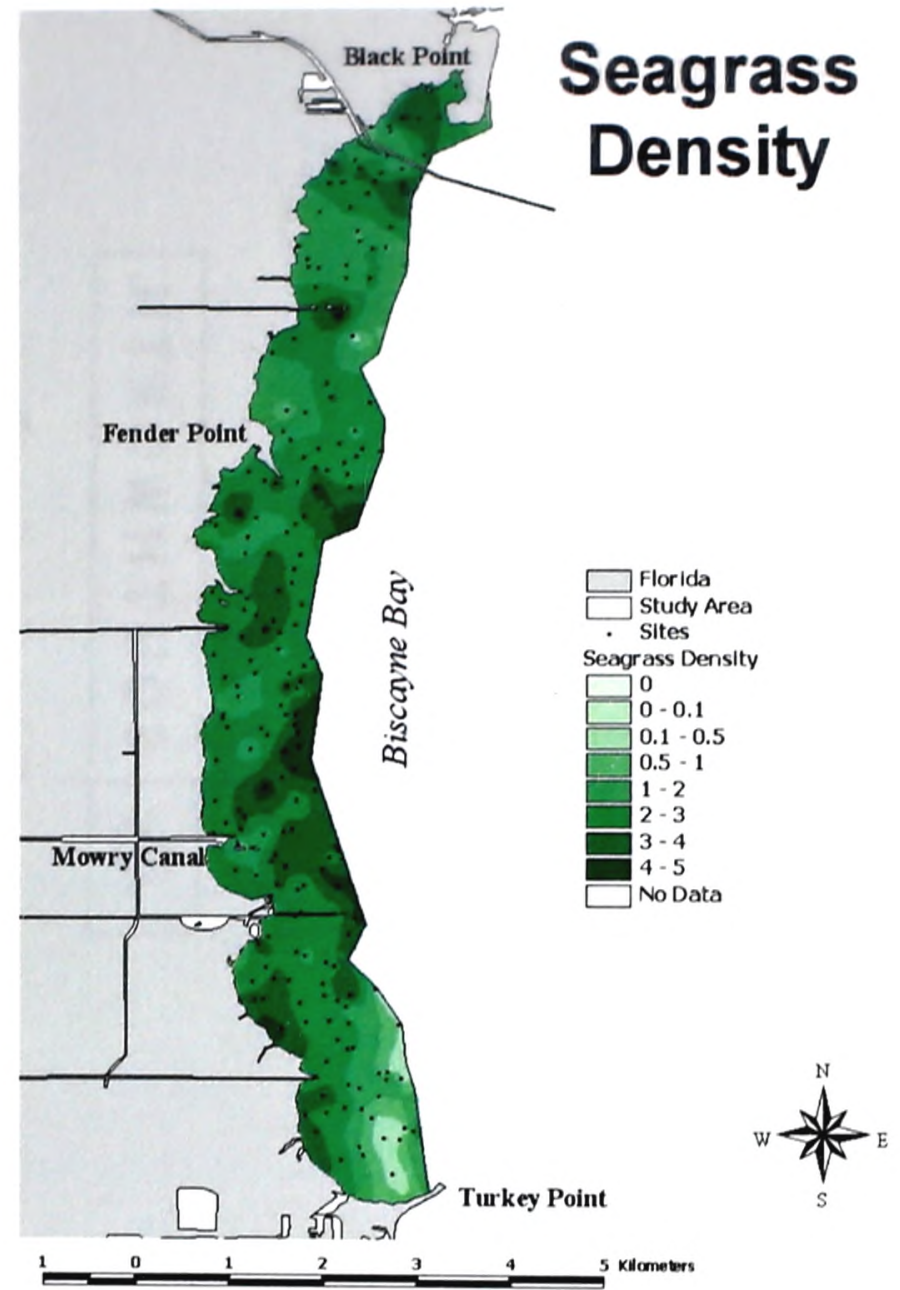

(a)

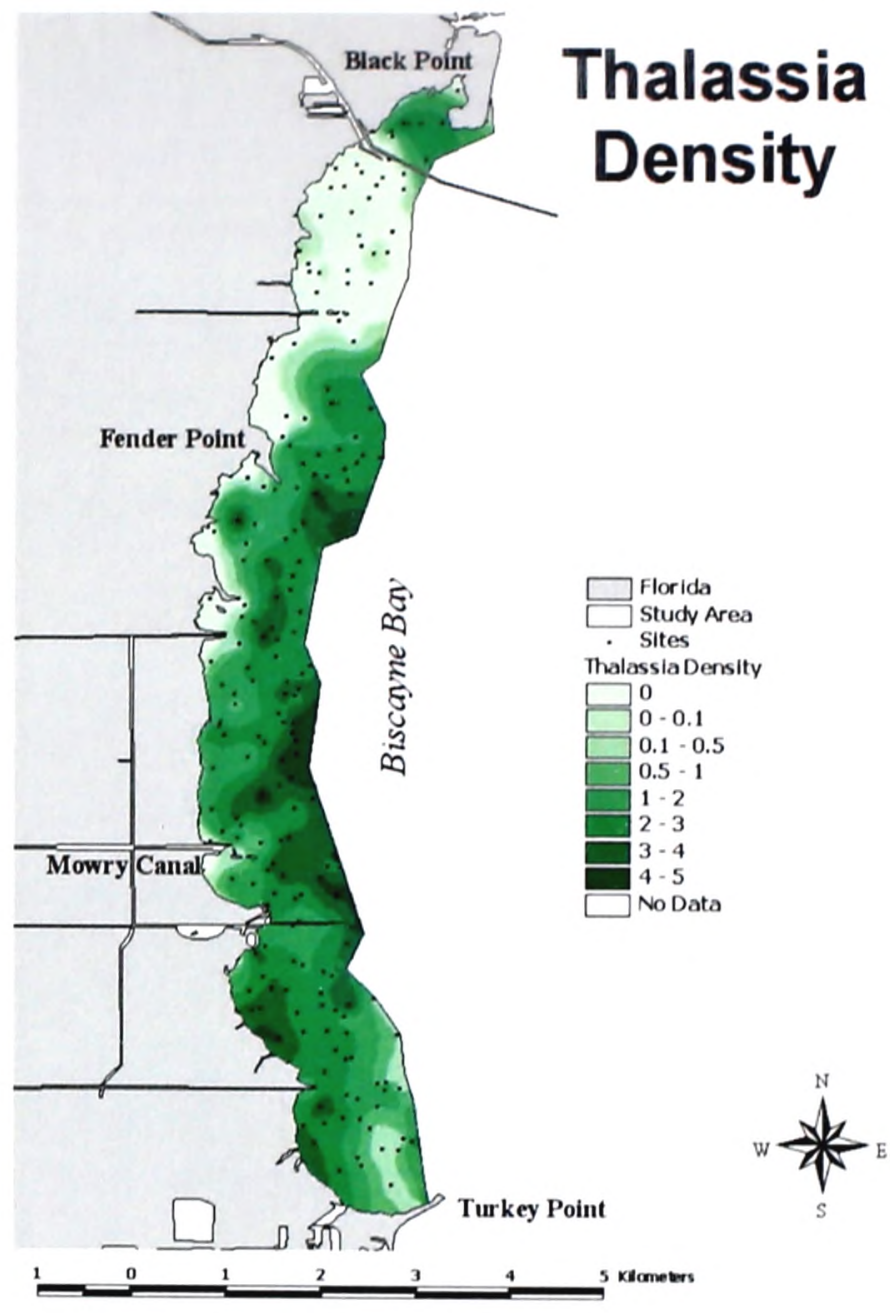

(b)

Figure 2.4. Interpolated distributions of nearshore benthic taxa groups; a) Seagrass density, b) Thalassia testudinum density. 


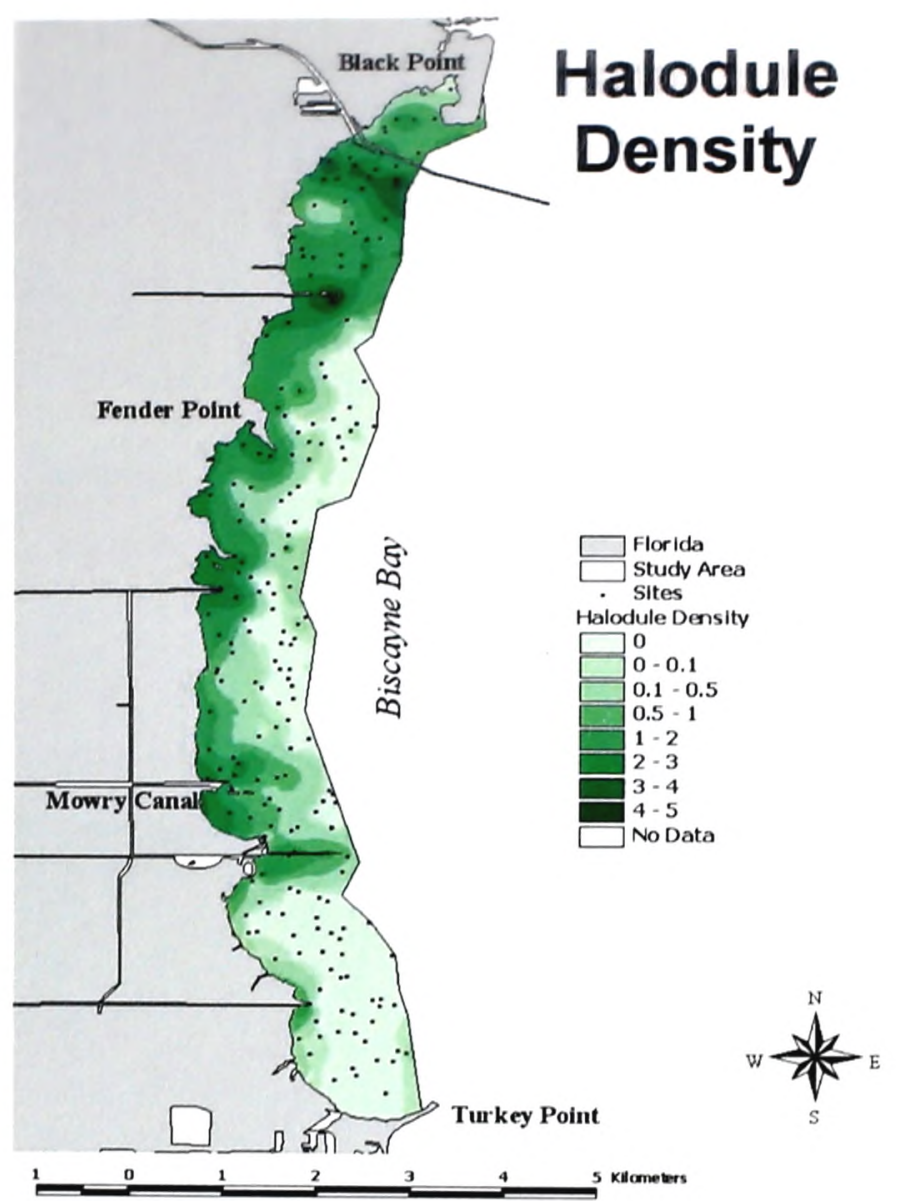

(c)

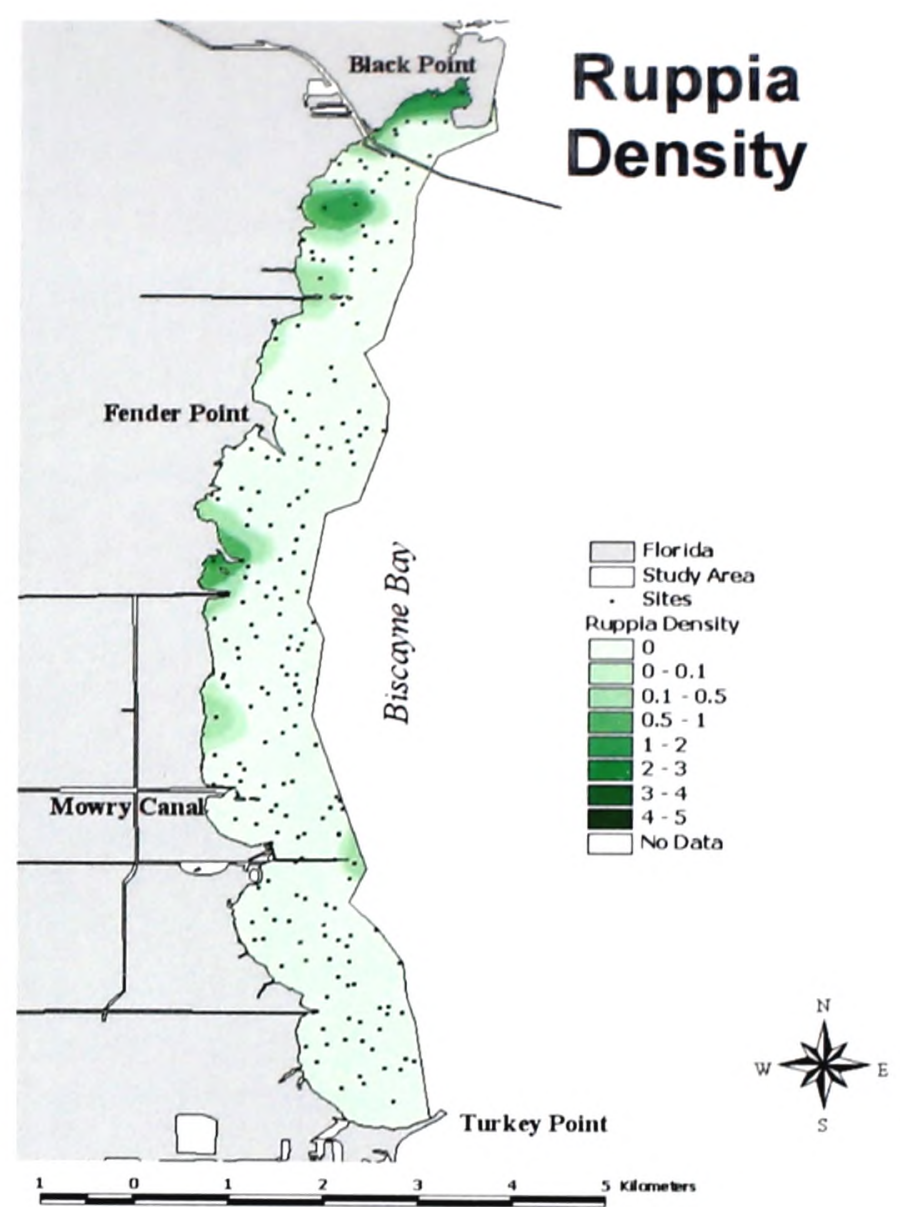

(d)

Figure 2.4. Interpolated distributions of nearshore benthic taxa groups; c) Halodule wrightii density, d) Ruppia maritima density. 


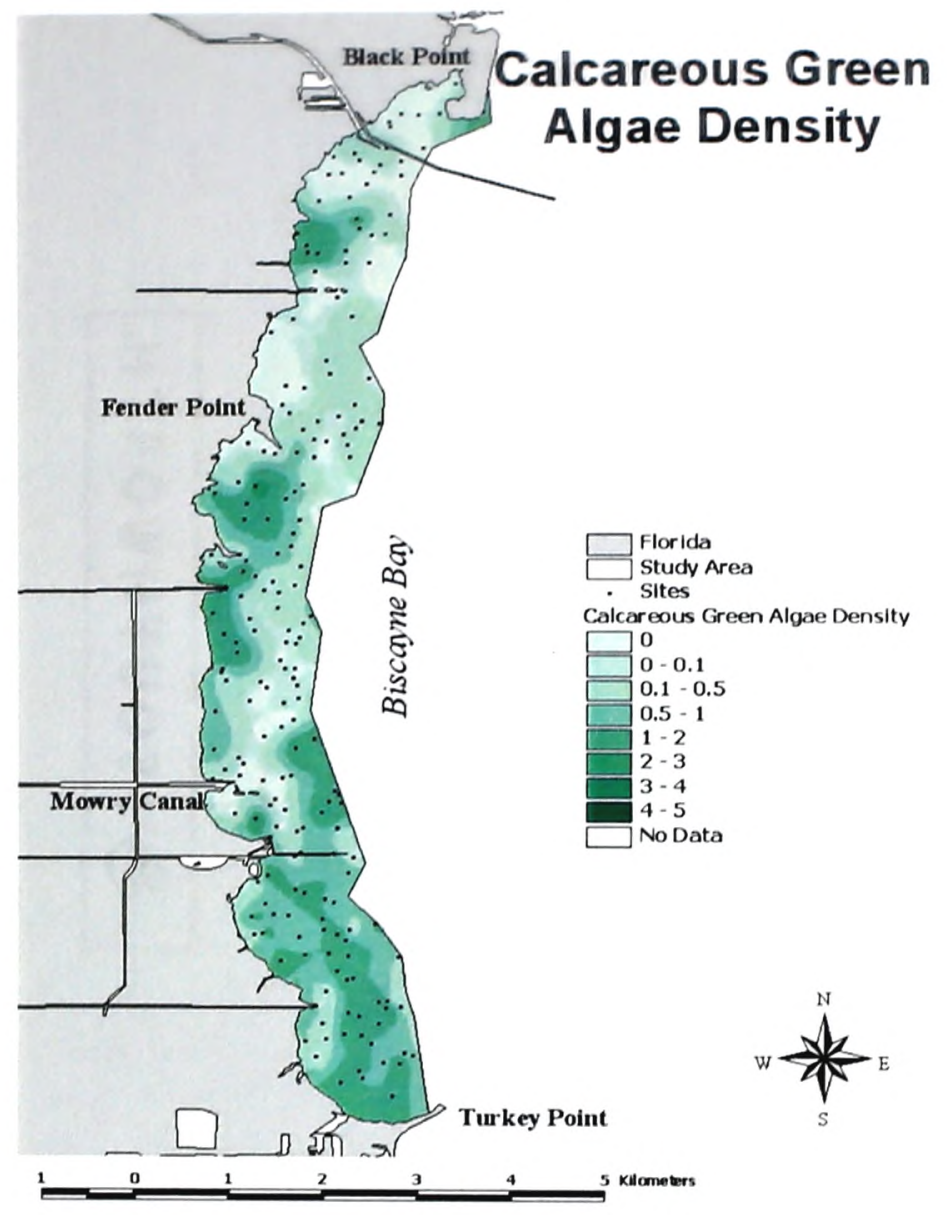

(e)

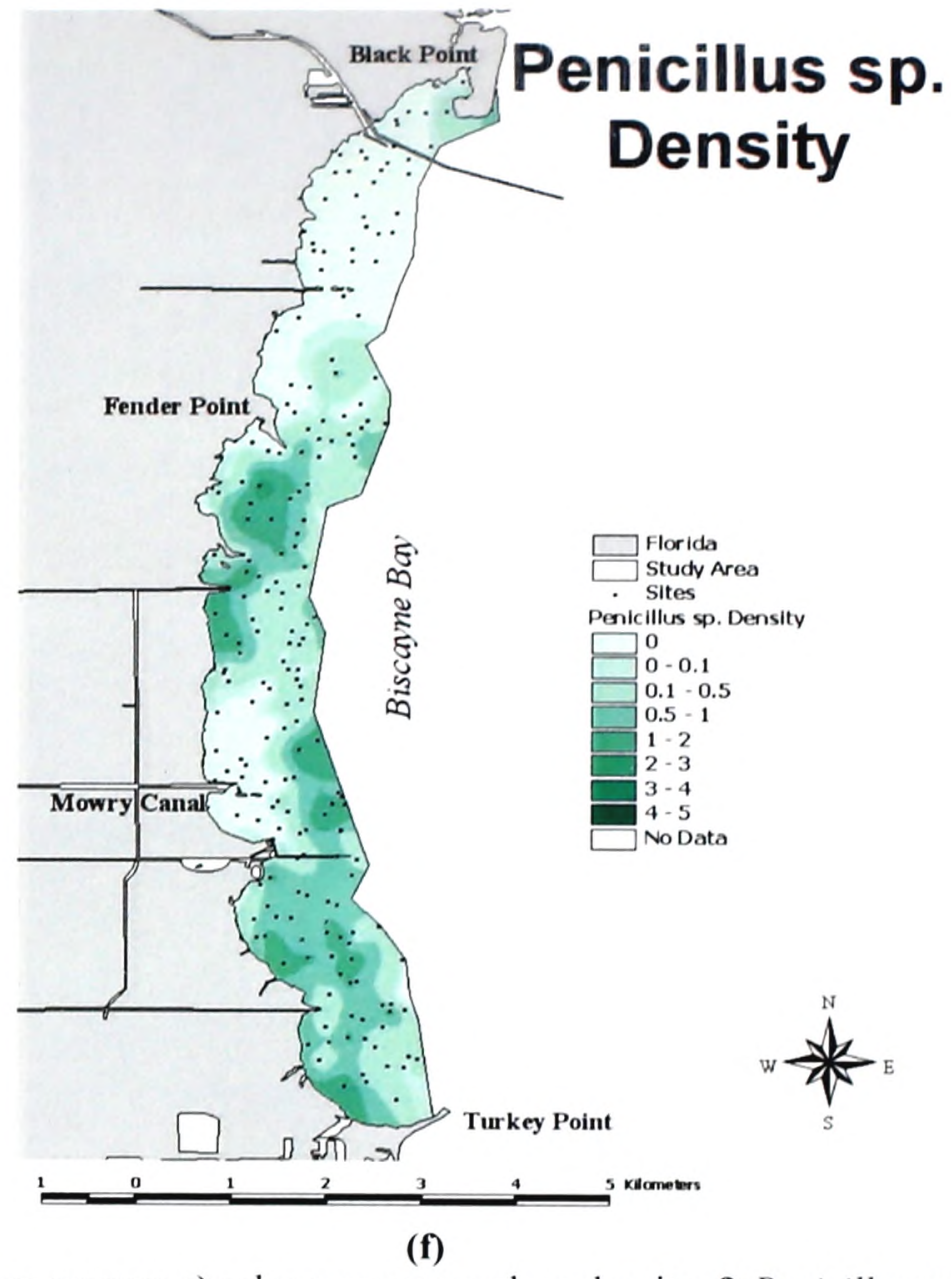

Figure 2.4. Interpolated distributions of nearshore benthic taxa groups; e) calcareous green algae density, f) Penicillus sp. density. 


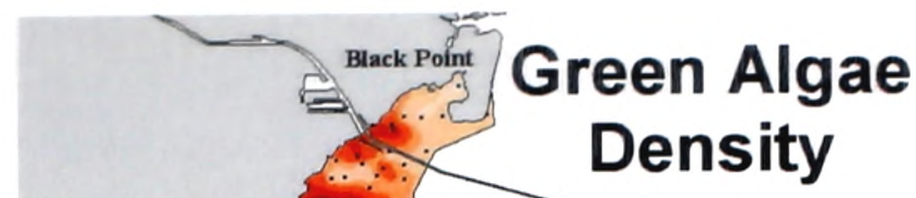

Turkey Point

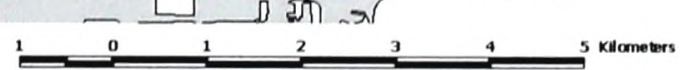

(g)

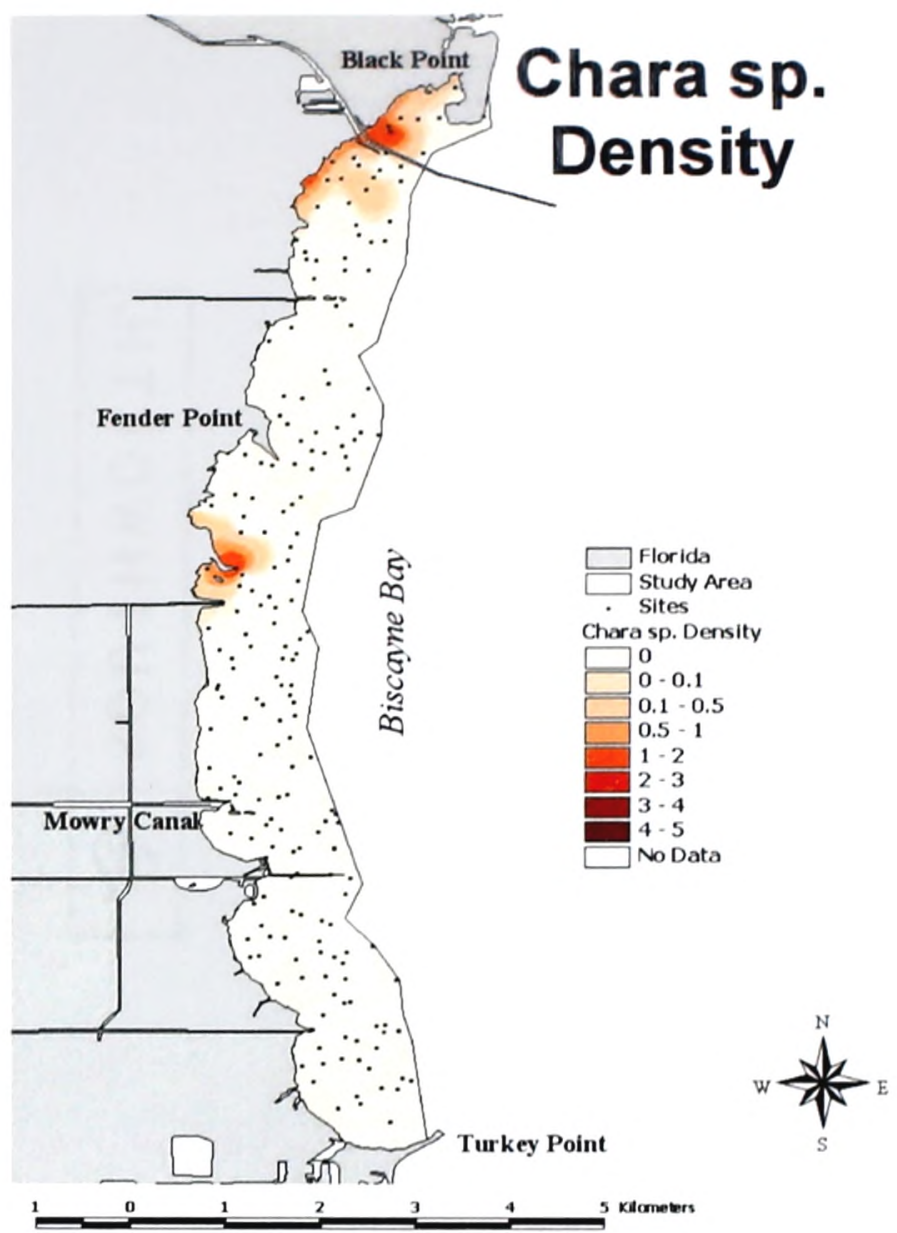

(h)

Figure 2.4. Interpolated distributions of nearshore benthic taxa groups; g) total green algae density, h) Chara sp. density. 


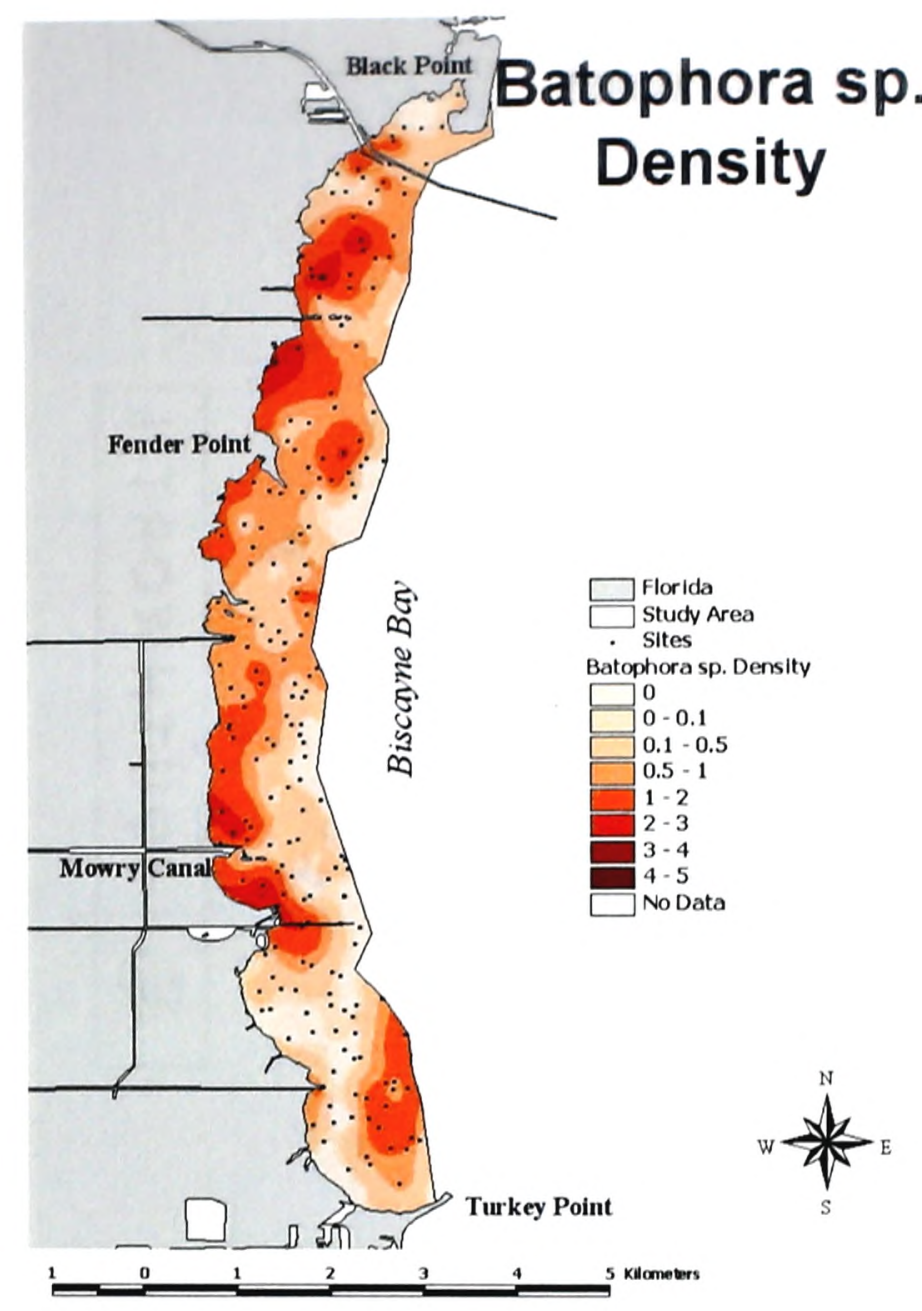

(i)

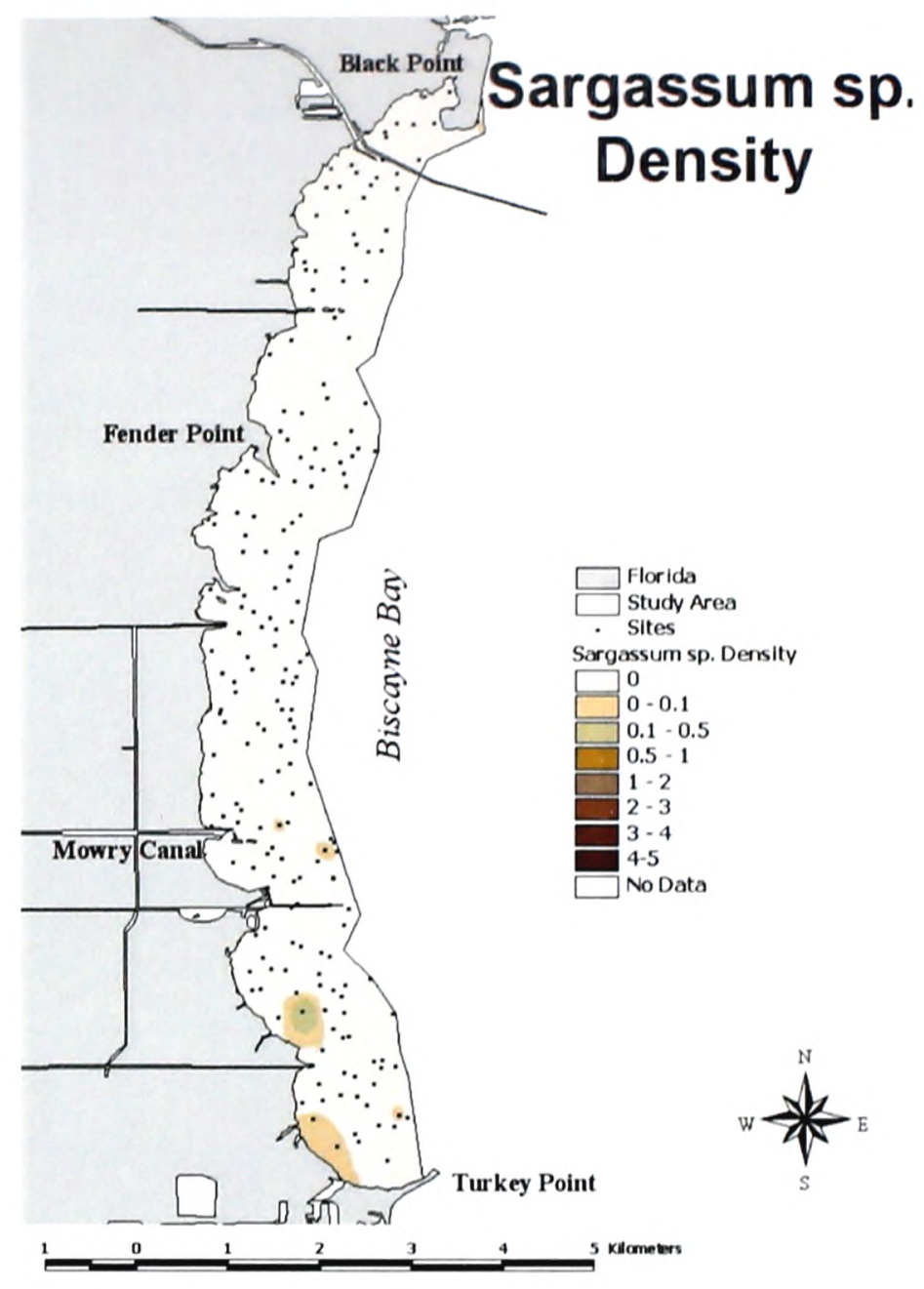

(j)

Figure 2.4. Interpolated distributions of nearshore benthic taxa groups; i) Batophora sp. density, j) Sargassum sp. density. 


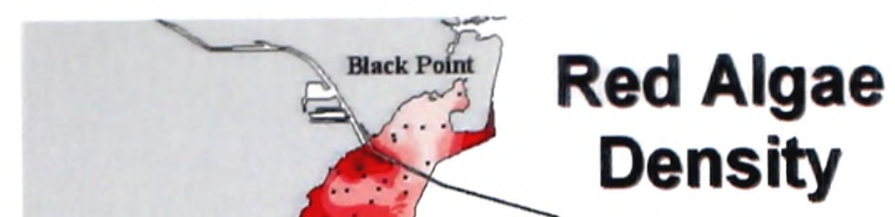

$\square$ Florida
Study Area Sites Density $\square 0$

$0-0.1$
$0.1-0.5$

$0.1-0.5$
$0.5-1$

$1-2$
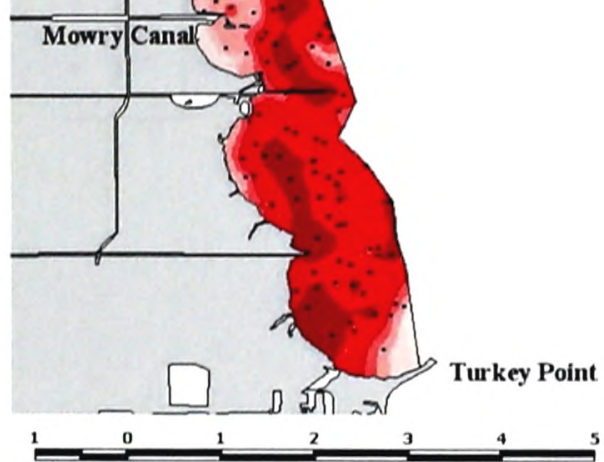

(k)

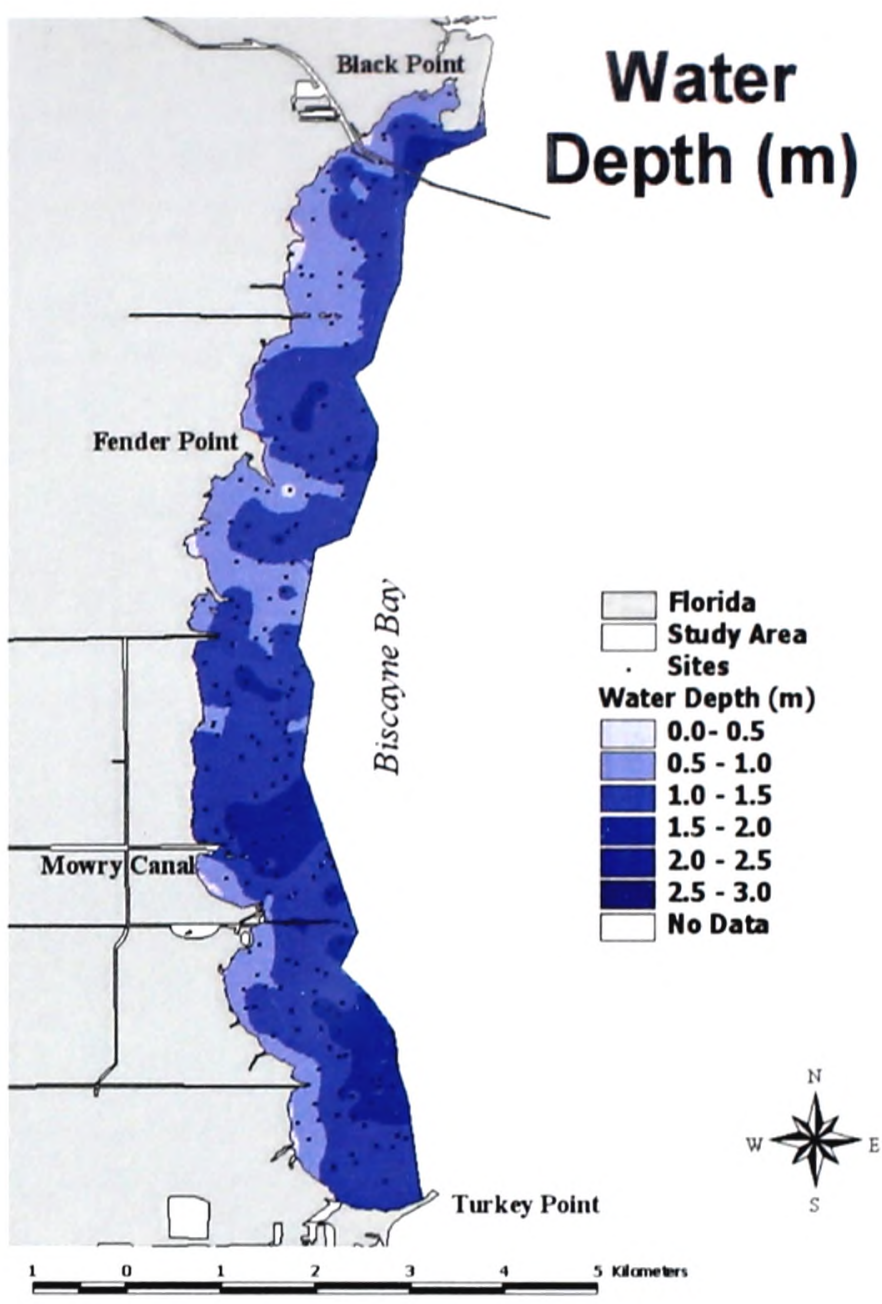

(I)

Figure 2.4. Interpolated distributions of benthic taxa and physical parameters; $\mathbf{k}$ ) total red algae density, l) water depth (m). 


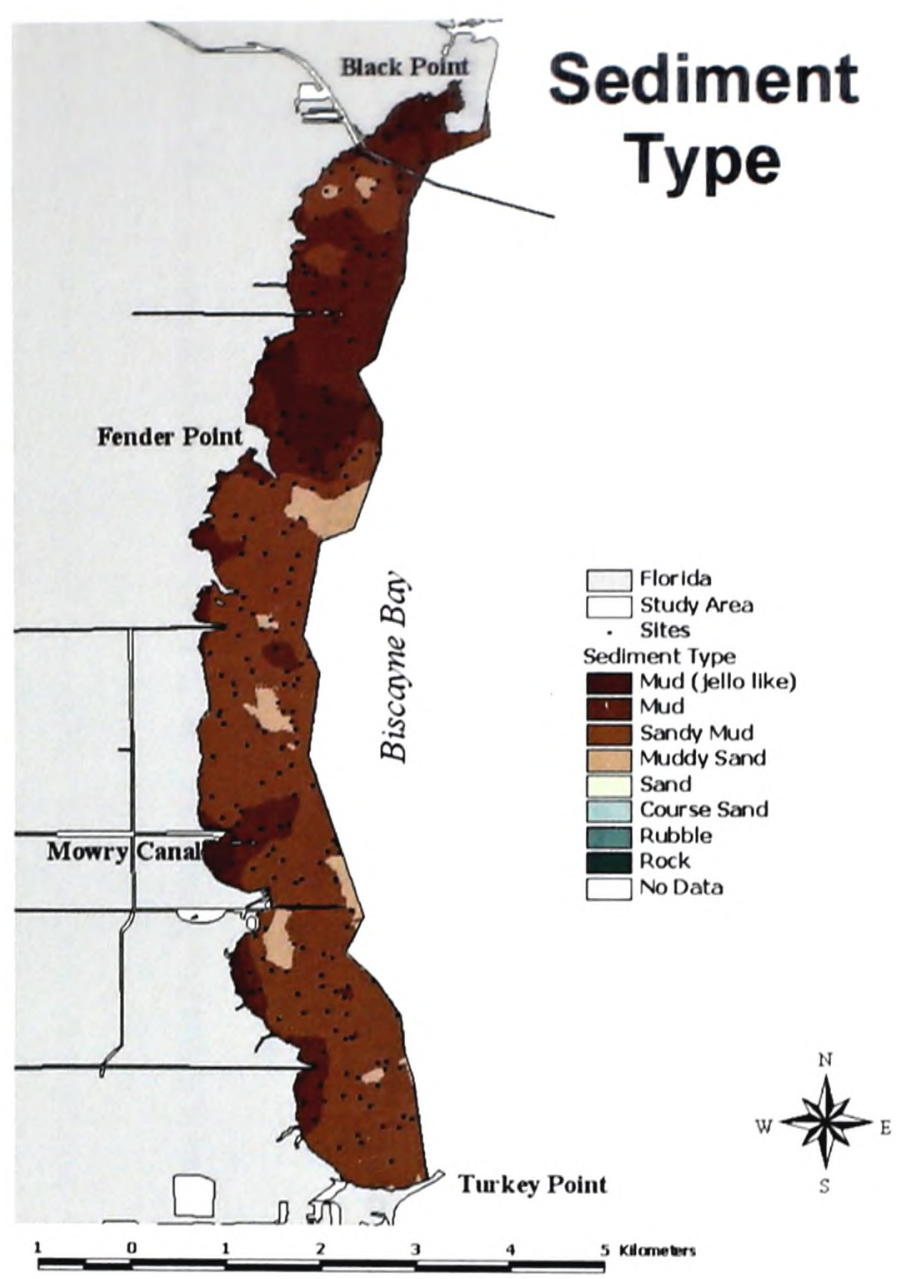

(m)

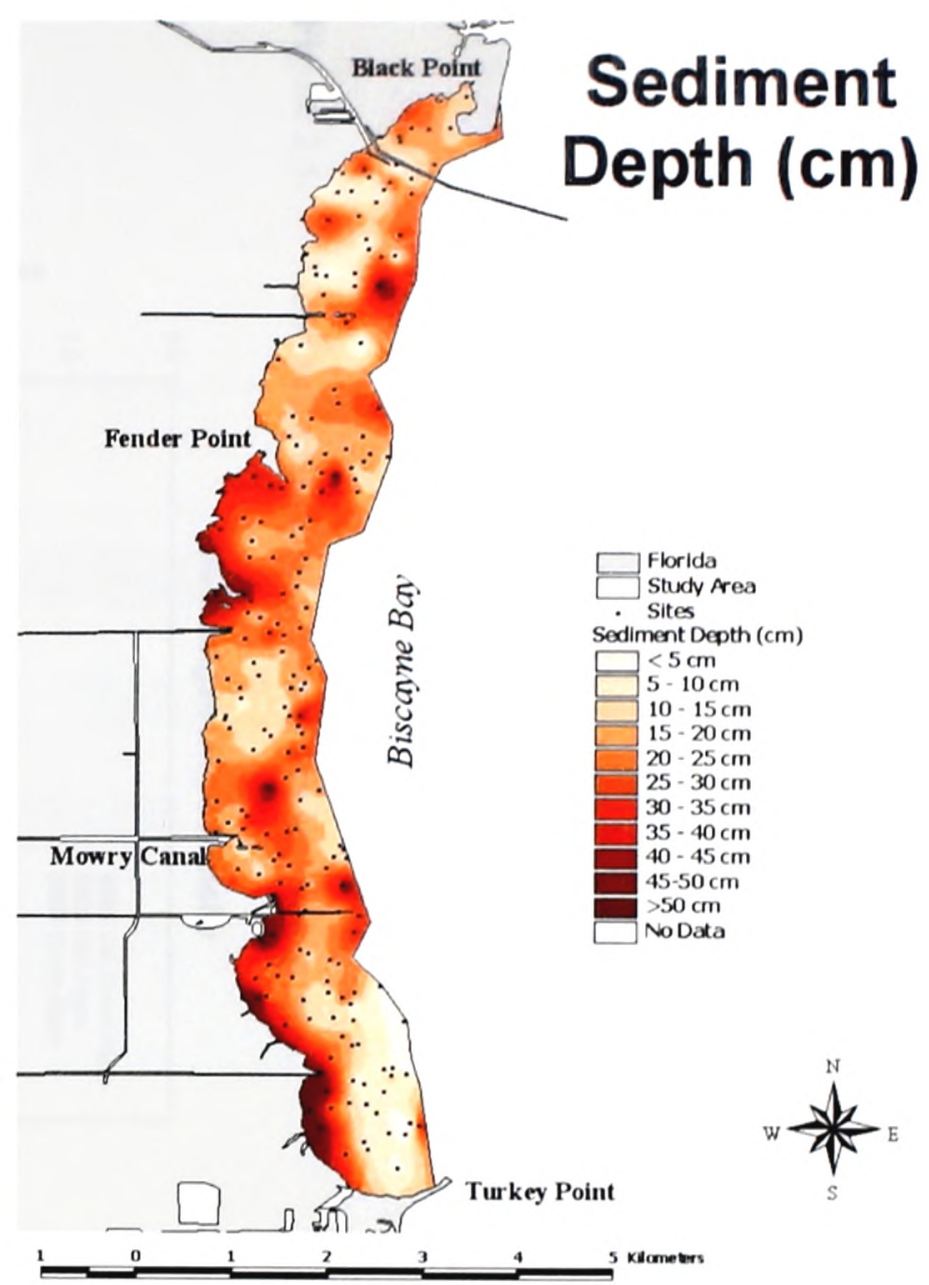

(n)

Figure 2.4. Interpolated distributions of nearshore physical parameters; m) sediment type, $\mathbf{n})$ sediment depth (cm). 


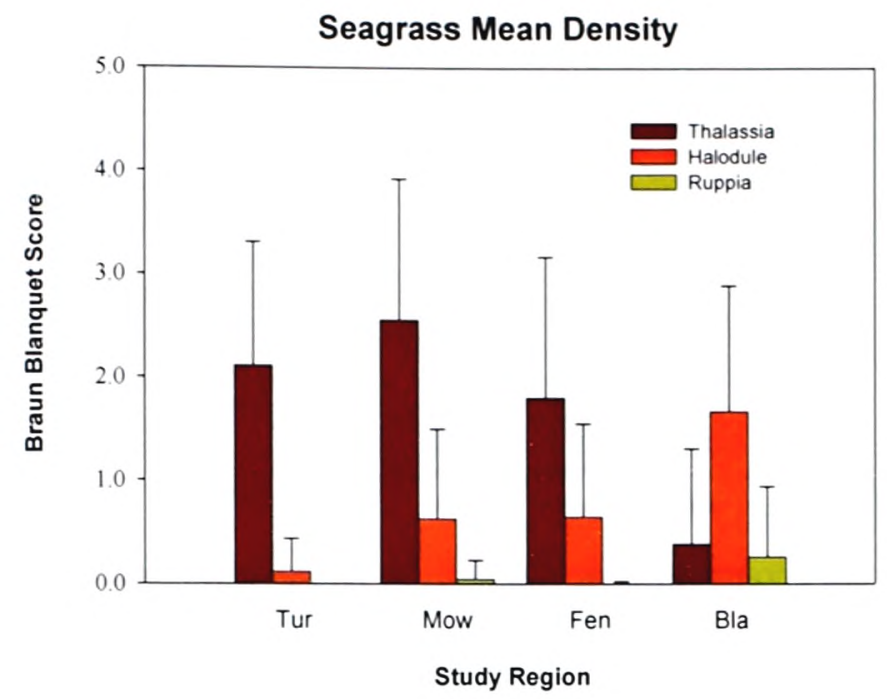

Figure 2.5. Mean seagrass density among site location groups.

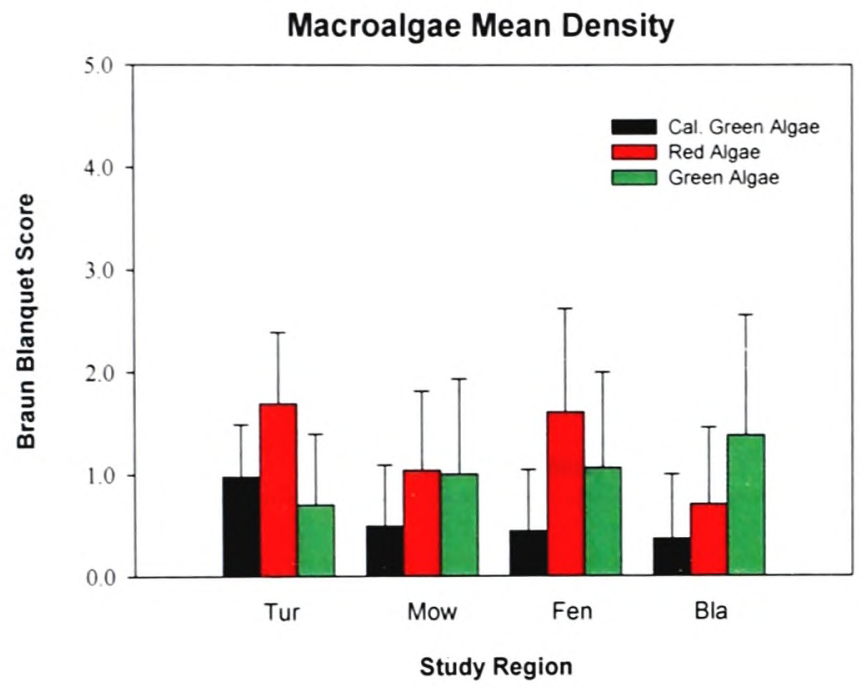

Figure 2.6. Mean macroalgae groups density (Braun-Blanket score) for taxa that were significantly different among site location groups.

Groups represented are calcareous green algae (CGT), green algae (GRT) and red algae (RDT). 


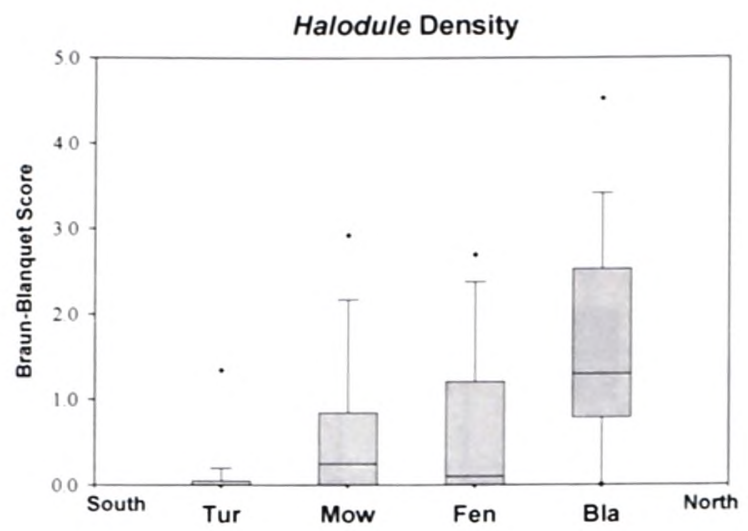

Figure 2.7. Box-and-whisker plot of Halodule wrightii among the study areas.

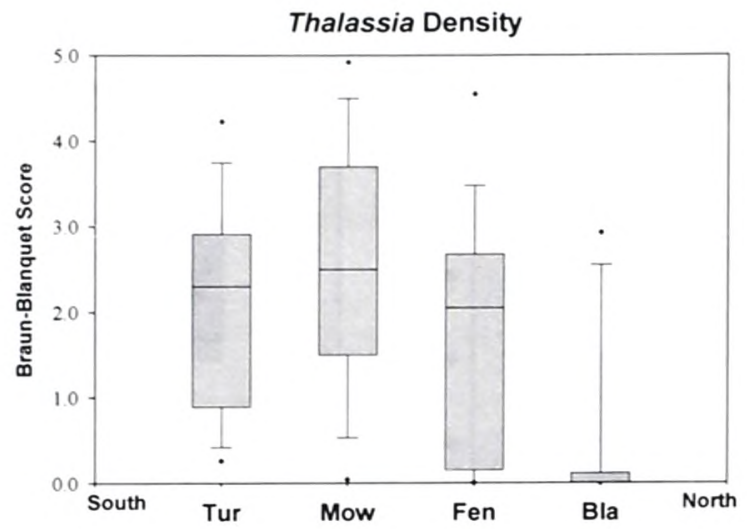

Figure 2.8. Box-and-whisker plot of Thalassia testudinum among the study areas.

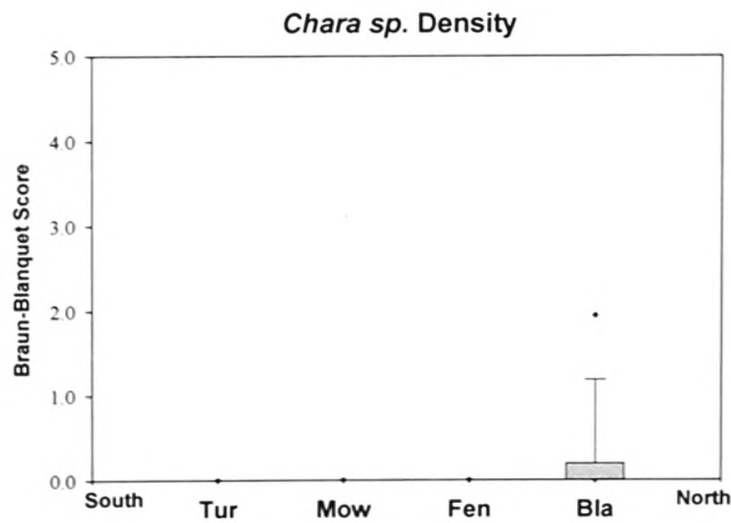

Figure 2.9. Box-and-whisker plot of Chara sp. among the study areas. 

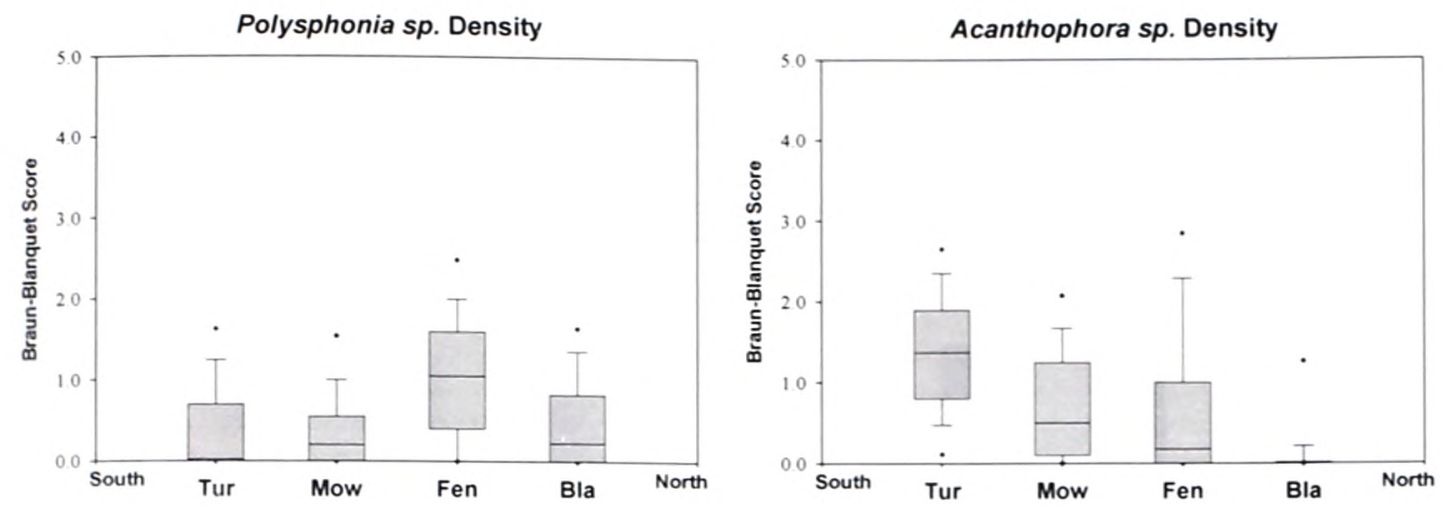

Figure 2.10. Box-and-whisker plots of two red algae genera density (Polysiphonia sp. and Acanthophora sp.) among study areas.
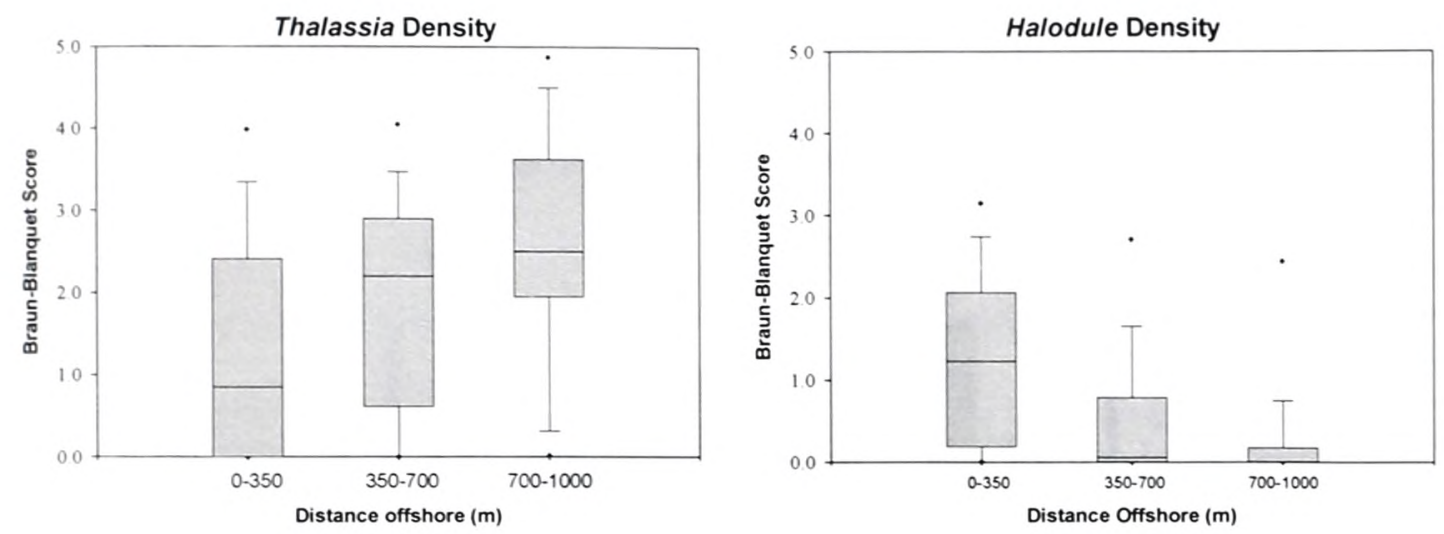

Figure 2.11. Box-and-whisker plots of Thalassia testudinum and Halodule wrightii among distances offshore.

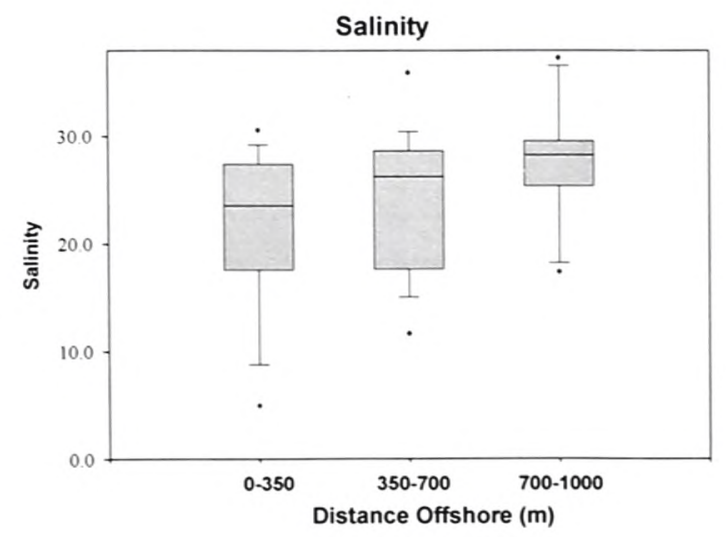

Figure 2.12. Box-and-whisker plots of salinity among distances offshore. 

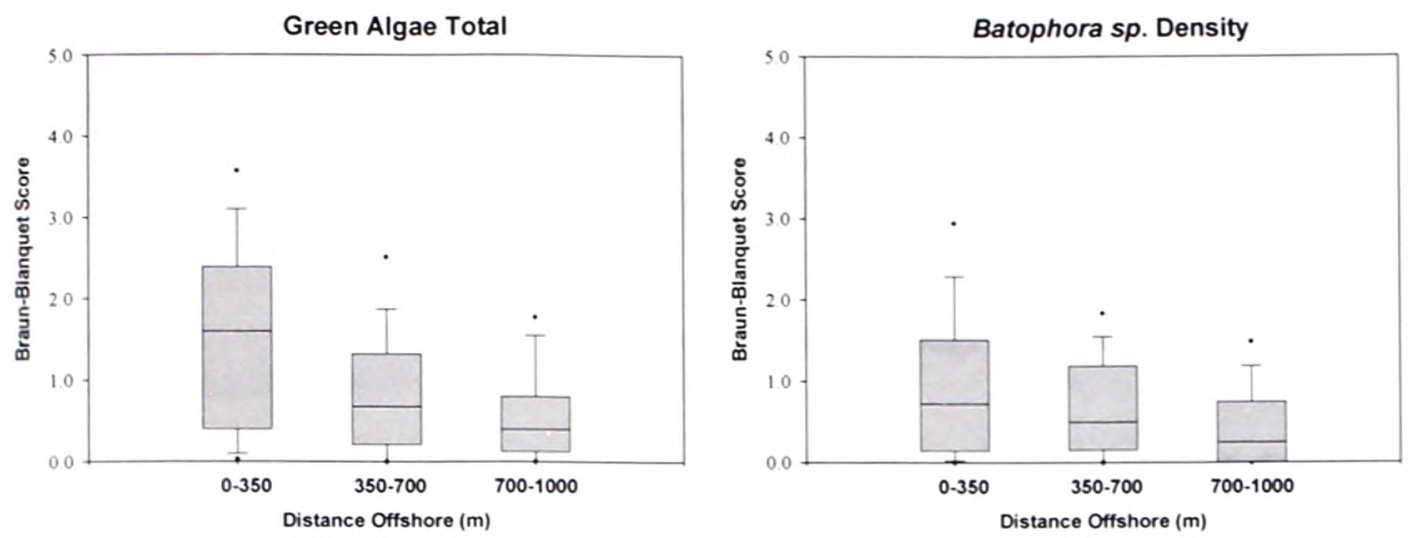

Figure 2.13. Box-and-whisker of green algae total density (Batophora sp., Cheatomorpha sp., Cladophora sp.) and Batophora sp. density (dominate species) among distances offshore.

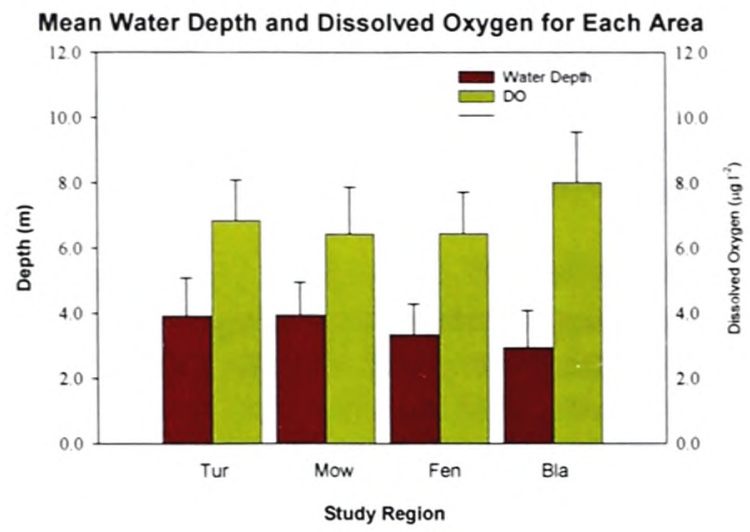

Figure 2.14. Mean water depth (m) and dissolved oxygen for each study area. 


\section{Work Cited}

Alleman, R. W., S. A. Bellmund, D. W. Black, S. E. Formati, C. A. Gove, and L. K. Gulick. 1995. Biscayne Bay Surface Water Improvement and Management: technical supporting document. Planning Department of SFWMD, West Palm Beach.

Bokuniewicz, H., and B. Pavlik. 1990. Groundwater seepage along a Barrier Island. Biogeochemistry 10:257-276.

Braun-Blanquet, J. 1972. Plant sociology: the study of plant communities. Hafner Publishing Company, New York.

Byrne, M. J. 1999. Groundwater nutrient loading in Biscayne Bay, Biscayne National Park. Master's. Florida International University, Miami.

Caccia, V. G., and J. N. Boyer. 2005. Spatial patterning of water quality in Biscayne Bay, Florida as a function of land use and water management. Marine Pollution Bulletin 50:1416-1429.

Fourqurean, J. W., J. N. Boyer, M. J. Durako, L. N. Hefty, and B. J. Peterson. 2003. Forecasting the response of seagrass distribution to changing water quality: Statistical models from monitoring data. Ecological Applications 13:474-489.

Fourqurean, J. W., M. Durako, M. O. Hall, and L. N. Hefty. 2002. Seagrass distribution in south Florida: A multi-agency coordinated monitoring program. Pages 497-522 in P. J.W. and K. G. Porter, editors. The Everglades, Florida Bay, and Coral Reefs, of the Florida Keys An Ecosystem Sourcebook. CRC Press, Boca Raton.

Fourqurean, J. W., and L. M. Rutten. 2003. Competing goals of spatial and temporal resolution: monitoring seagrass communities on the regional scale. Pages 257-288 in D. E. Busch and J. C. Trexler, editors. Monitoring Ecosystems: Interdisciplinary Applications for Evaluation Ecoregional Initiatives. Island Press, Washington.

Fourqurean, J. W., A. Willsie, C. D. Rose, and L. M. Rutten. 2001. Spatial and temporal pattern in seagrass community composition and productivity in south Florida. Marine Biology 138:341-354.

Johannes, R. E. 1980. The ecological significance of the submarine discharge of groundwater. Marine Ecology Progress Series 3:365-373.

Kahn, A. E., and M. J. Durako. 2006. Thalassia testudinum seedling responses to changes in salinity and nitrogen levels. Journal of Experimental Marine Biology and Ecology 335:1-12. 
Kohout, F. A., and M. C. Kolipinski. 1967. Biological zonation related to groundwater discharge along the shore of Biscayne Bay, Miami, Florida. Pages 488-499 in Estuaries: American Association for the Advancement of Science.

Lietz, A. C. 1999. Methodology for estimating nutrient loads discharged from the east coast canals to Biscayne Bay, Miami-Dade County, Florida. Water Resources Investigations Report 99-4094, USGS, Tallahassee, FL.

Lirman, D., and J. W. P. Cropper. 2003. The influence of salinity on seagrass growth, survivorship, and distribution with Biscayne Bay, Florida: field, experimental, and modeling studies. Estuaries 26:131-141.

Meeder, J., and J. N. Boyer. 2001. Total ammonia concentrations in soil, sediments, surface water, and groundwater along the western shoreline of Biscayne Bay with the focus on Black Point and a reference mangrove site. BISC-N-011.000, Final Report to National Park Service, SERC, FIU, Miami.

Meeder, J. F., J. Alvord, M. Byrns, M. S. Ross, and A. Renshaw. 1997. Distribution of benthic nearshore communities and their relationship to groundwater nutrient loading. BNP, Final Report to Biscayne National Park, SERC, FIU, Miami.

Roessler, M., G. L. Beardsley, and R. Smith. 1973. Benthic Communities of Biscayne Bay, Florida. Pages 10 in. University of Miami Sea Grant Program.

Szmant, A. M. 1987. Biological investigations of the Black Creek vicinity, Biscayne National Park. SER-87, Biscayne National Park, National Park Service, U.S. Department of the Interior, Homestead.

Thorhaug, A. 1976. The vascular plants of Biscayne Bay. Pages 315+ in A. Thorhaug and A. Volker, editors. Biscayne Bay Symposium I. Sea Grant Program, University of Miami.

Valiela, I., J. M. Teal, S. B. Volkmann, C. M. Cogswell, and R. A. Harrington. 1980. On the measurement of tidal exchanges and groundwater flow in salt marshes. Limnology and Oceanography 25:187-192. 


\section{MEASURING THE RELATIONSHIP BETWEEN GROUNDWATER NUTRIENT LOADS AND BENTHIC MACROPHYTE COMMUNITIES}

\section{Introduction}

The structure and function of seagrass communities are influenced by both anthropogenic and natural environmental changes. As human populations continue to grow and establish along coastal areas, it has contributed to changes found in the quality, quantity and timing of freshwater runoff to estuarine environments. Light availability and nutrients are considered two of the primary physical factors that limit seagrass distribution (Dennison and Alberte 1985, Short 1987). Other environmental factors such as salinity, currents, temperature and sediment accumulation can influence community structure within a seagrass community.

Species with a greater ability to compete for the limiting resource (e.g. nutrients) at a given time can effect community composition based on resource models (Tilman 1982). Some species of macroalgae occur as blooms when waters are nutrient enriched. Macroalgae typically have a broader range of ecological effects and last longer than microalgal blooms, and they can displace seagrasses, corals, or brown algae (Valiela et al. 1997). These blooms are usually unattached or filamentous green algal species. Light attenuation generally increases, due the dominance of fast growing macroalgae and phytoplankton (Figure 1.1) (Duarte 1995, Fourqurean and Rutten 2003).

Seagrass species have individualized nutrient and salinity tolerances that can effect their distribution. Seagrass systems, especially Thalassia testudinum, in Florida Bay tend to retain and recycle acquired nutrients efficiently allowing them to better in 
oligotrophic conditions (Fourqurean 1995). Powell et al. (1991), documented species zonation in Florida Bay, where H. wrightii and R. maritima was dominant close to nutrient point sources, while T. testudinum became dominant with increasing distance from the point source. Once the limitation of nutrients is eliminated, H. wrightii is a better competitor for light therefore, eventually out competes T. testudinum, unlike in oligotrophic conditions when T. testudinum is more efficient at retaining nutrients (Fourqurean et al. 1995).

Nitrogen $(\mathrm{N})$ and phosphorus $(\mathrm{P})$ are two major nutrients that limit species composition within seagrass communities. Nitrogen is made available to the seagrass and rhizophytic macroalgae by four major sources: (1) the water column (in low concentrations); (2) organic matter decomposition in sediments; (3) fixation of nitrogen within the plant rhizosphere; and (4) submarine groundwater discharge. Phosphorus typically originates from three main sources: (1) regenerated P from organic or inorganic material in the sediments; (2) low P concentrations present in the oligotrophic surface water (Short et al. 1985); and (3) from contaminated groundwater discharge. Seagrass communities characteristically exhibits high degree of nutrient conservation and recycling of nutrients through the utilization of sediment nutrients (Short 1987).

Seagrass beds have generally been considered to be phosphorus (P)-limited in carbonate environments (Smith 1984, Smith and Atkinson 1984, Short et al. 1985, Howarth 1988, Short et al. 1990, Fourqurean et al. 1992b) and nitrogen (N)-limited in sandy, terrigenous environments (Short 1987). Leaf or total plant nitrogen: phosphorus $(\mathrm{N}: \mathrm{P})$ molar ratios of $30: 1$ are the modified Redfield ratio for seagrasses which serve as a useful tool in determining P or N-limitations (Atkinson and Smith 1983). Phosphorus 
limitation is typically demonstrated with $\mathrm{N}: \mathrm{P}>30: 1$ and ratios $<30: 1$ indicate $\mathrm{N}$ limitation. Redfield ratios are a proxy for relative nutrient (phosphorus or nitrogen) availability to plants (Atkinson and Smith 1983, Fourqurean et al. 1992a).

Ecosystem of Biscayne Bay, Florida.

Biscayne Bay is located near $25^{\circ} 45^{\prime} \mathrm{N}$ and $80^{\circ} 15^{\prime} \mathrm{W}$ on the southeastern coast of Florida (Figure 3.1). The Surface Water Improvement and Management Plan (SWIM) for Biscayne Bay separated the bay into three distinct regions: North, Central and South Bay (Alleman et al. 1995). North Bay is the most highly urbanized of the three. The construction of Haulover Cut, an intracoastal channel and the enlargement of Government Cut have changed circulation patterns, resulting in increased salinity (Alleman et al. 1995). The Central Bay's western shore was originally composed of a mangrove fringe and extensive freshwater marshes. These freshwater marshes were maintained by local rainfall and Everglades' runoff from the transverse glades. The glades were channeled and drained directly into Biscayne Bay after the turn of the century, which resulted in saltwater intrusion. South Bay, the focus of this study, is relatively undeveloped, although it receives drainage from canals, landfills, agriculture and urban areas. Canals flow into the Bay by two distinct interconnected drainage systems known as the South Dade coastal drainage and the conveyance system drainage areas (Alleman et al. 1995).

In South Bay's nearshore seagrass community, Thalassia testudinum is found offshore, with Halodule wrightii dominating as a thin ban along the shore (Chapter 2). Brackish water macroalgae (e.g. Chara sp.) and seagrass Ruppia maritima are found near 
potential freshwater discharge from canals and groundwater along the shoreline and near Black Point (Chapter 2). The entire area is shallow and allows light to penetrate to the substrate. Salinity fluctuations and nutrient loading from canals have been shown to affect benthic community structure in the receiving waters (Meeder and Boyer 2001). Thalassia testudinum has shown seasonal changes due to annual fluctuations of temperature and salinity in Biscayne Bay (Zieman 1975). High ammonium $\left(\mathrm{NH}_{4}{ }^{+}\right)$ concentration were found along the shoreline at Black Point, an area in the south region of Biscayne Bay, (Meeder and Boyer 2001).

\section{Factors that Potentially Effect Seagrass Communities}

The reduction and infrequency of freshwater inputs by management modifications in south Florida may influence seagrass mortality due to conditions in Florida Bay oscillating between hypersaline and brackish (Robblee et al. 1991). Growth and productivity of seagrass species may be reduced at sites influenced by freshwater discharge (Montague, 1989). One study showed that Thalassia testudinum typically decreases with lowered salinity and can be dominant in a nearshore environments only when salinity values are not drastically lowered eventually allowing Halodule wrightii to out compete T. testudinum (Lirman and Cropper 2003). Much of the work done on seagrass tolerance to salinity ranges have been on mature plants. Kahn \& Durako (2006) suggests that the salinity tolerance for T. testudinum is not as broad as what has been reported. They found recruitment of $T$. testudinum seedlings to be negatively effected with increased freshwater especially if co-occurring with elevated ammonium (Kahn and 
Durako 2006). Another report shows that high $\mathrm{NH}_{4}{ }^{+}$concentrations at Black Point are related to a lower abundance of T. testudinum (Meeder and Boyer 2001).

Groundwater as a Source of New Nutrients in Biscayne Bay

Many studies have focused on anthropogenic nutrient inputs from rivers, atmosphere, and non-point runoff (e.g. storm water). One often-overlooked source of nutrients is from submarine groundwater discharge (SGD). Along many coasts, submarine groundwater discharge is close to shore (Valiela et al. 1980). Groundwater discharge and its effects on benthic vegetation are not well studied in estuarine areas, with about 20-30 published studies done globally. It has been estimated that SGD contributes three to five times as much nitrogen to an estuary as does surface water (Johannes 1980), which has the potential to significantly impact water quality of shallow estuaries. Misinterpretations of ecological data relating to benthic zonation and productivity can occur by neglecting to incorporate SGD. Through the use of $\delta^{15} \mathrm{~N}$, groundwater showed a relationship with nitrogen contributed from the costal watershed and what was used by primary producers (McClelland and Valiela 1998). In some areas, anthropogenic activities have increased groundwater nutrients and loading of these nutrients, which may lead to problems in the nearshore environment (Lapointe et al. 1990). Submarine groundwater discharge is common wherever there is an aquifer with a head above sea level connected to overlying surface waters through fissures or permeable strata (Johannes 1980). Groundwater input has been shown to decrease rapidly with distance from shore (e.g. Bokuniewicz and Pavlik 1990, Meeder et al. 1997, Byrne 1999). 
Groundwater transports nutrients from the watershed seaward, and the nutrients from discharge may be far more significant than what has been realized (e.g. Johannes 1980, Bokuniewicz and Pavlik 1990, Valiela et al. 1990). Increases in anthropogenic nutrients entering the groundwater eventually discharging in shallow estuaries may have a great impact on benthic macrophyte communities. In Biscayne Bay, SGD decreases rapidly in offshore to zero at about 400 meters (Meeder et al. 1997, Byrne 1999). Byrne (1999) documented that the greatest discharge was at 185 meters offshore, which decreased to zero at $400 \mathrm{~m}$ around Mowry Canal. Meeder et al. (1997) found groundwater salinity was the lowest at 50 meters offshore and increased to marine levels at their offshore stations. However, Kohout \& Kolipinski (1967) calculated freshwater discharges to the bay as far as $2 \mathrm{~km}$ offshore. Differences found by Kohout (1967) from more recent studies could be caused by; 1) their methodology, method of calculating discharge is no longer used by hydrologists, and/or, 2) conditions of the watershed have decreased the hydraulic head.

Meeder et al. (1997) found that the groundwater $\mathrm{NH}_{4}{ }^{+}$concentrations at Black Point were the highest in Biscayne Bay and decreased by nearly $50 \%$ in both northward and southward directions. Thalassia testudinum was absent in areas receiving groundwater discharge (Kohout and Kolipinski 1967). Influences to seagrass communities caused by groundwater sources typically decrease with distance from shore. A report to Biscayne National Park showed that the nearshore community is dynamic, with the first few hundred meters being dominated by Halodule wrightii then Penicillus sp. and Batophora sp. further out, while at 800 meters the community was dominated by Thalassia testudinum (Meeder et al. 1997). Studying the relationships between 
macrophytes and groundwater may give us a better insight on the ecological processes involved and help managers within this system.

\section{Objectives}

The purpose this study is to determine if groundwater nutrient inputs are correlated with nearshore benthic macrophyte communities in southwestern Biscayne Bay. The combination of high nutrient availability (landfills, sewage treatment plants, urban and agricultural runoff), elevated $\mathrm{NH}_{4}{ }^{+}$concentrations and decreased abundance of T. testudinum at Black Point (north end of study area) makes this area interesting to researchers. Studies in Biscayne Bay have shown that groundwater has the greatest effect on nearshore benthic community dominance and provides a more constant flow of nutrients than run-off (Meeder et al. 1997). Documenting the processes and their resulted environmental impacts in southwestern Biscayne Bay is important for environmental managers and regulators in order to restore historic conditions or reduce further degradation. The following are the hypotheses tested:

H1: Groundwater nutrient discharge contributes more to the spatial variability in nearshore benthic species dominance in southern Biscayne Bay than canal discharge.

$\mathrm{H} 2$ : Variation in nearshore benthic community structure, the shift from Thalassia to Halodule, is significantly related to groundwater nutrient concentrations. 
Methods

\section{Location}

This study took place along the western shoreline of Biscayne Bay between Black Point and Turkey Point (Figure 3.1). L-31E Canal and storm protection levee runs parallel to shore about $0.6-1$ kilometer $(\mathrm{km})$ inland. Within this $11.5 \mathrm{~km}$ stretch, four transects were established which extended from 50 meters $(\mathrm{m})$ to $600 \mathrm{~m}$ offshore. The first transect (Tur) was located approximately $800 \mathrm{~m}$ north of Turkey Point; Transect 2 (Mow) was 400 m north of Mowry Canal; Transect 3 (Fen) was 200 m south of Fender Point; and Transect 4 (Bla) was 700 m south of Black Creek and Goulds Canal Channel at Black Point. Turkey Point and Fender Point have little or no canal discharge in contrast to Mowry and Black Point area which have very high discharge from Mowry, Military, Black Creek and Goulds Canal (Figure 3.2). Transects Mow and Bla includes both shallow and deep observation well for groundwater nutrient analysis.

\section{Project Design}

Transects were sampled bimonthly beginning in August 2002 and ending July 2003. Each transect contained five sites at distances of 50, 150, 300, 400, and $600 \mathrm{~m}$ offshore, for a total of 20 -sites in the study area. Sites were not placed less than $50 \mathrm{~m}$ offshore as the vegetation may be exposed at low tides and are susceptible to high sediment accumulation nearshore and rapid salinity changes. All transects where set up after the synoptic benthic macrophyte habitat was assessed (see Chapter 2). Locations of sites and distance offshore were based on previous research done in the southwest region of Biscayne Bay. Communities in this area went from a dense Halodule wrightii 
community nearshore, $H$. wrightii mixed with algae to a $T$. testudinum dominated system offshore within 1 kilometer (Kohout and Kolipinski 1967, Roessler et al. 1973, Thorhaug 1976, Szmant 1987, Meeder et al. 1997, Chapter 2). Benthic community variation from north to south and the absence T. testudinum at Bla dates back to the 1970's (Roessler et al. 1973, Thorhaug 1976, Szmant 1987, Meeder and Boyer 2001). Transects were placed in areas of different conditions such as: High groundwater plus low canal discharge, high groundwater plus high canal discharge, etc., based on known canal discharge rates and the hydraulic head in the area in order to help factor out canal discharge.

Groundwater flow (discharge) and its associated nutrient concentrations were investigated in a longitudinal and latitudinal direction to determine if there is a correlation with the spatial variation of community assemblages. Seepage meters were installed to measure discharge rates and nutrient concentrations of groundwater. Seepage meters were installed at the first three sites $(50,150 \& 300 \mathrm{~m})$ of each transect (12 meters total); restrictions set by Biscayne National Park prohibited placement of meters at every site. Seepage meters were placed within $300 \mathrm{~m}$ of shore based on previous flow rates found by Byrne (1999) and changes found within the nearshore community structure (Meeder et al, 1997).

\section{Benthic Community Structure and Physical Parameter Attributes}

Data characterizing the community structure (species dominance) were recorded for all benthic macrophyte type along with physical parameters (e.g. water depth, sediment type and depth). At each site, seagrass species and non-epiphytic macroalgae community composition were assessed in situ using a modified Braun Blanquet quadrat 
method of all taxa. Five of the $0.25 \mathrm{~m}^{2}$ quadrats were haphazardly placed while swimming $15 \mathrm{~m}$ north and another 5 placed within $15 \mathrm{~m}$ south of the rebar that marked the site. In each quadrat, taxa were assigned a unit-less score between 0 and 5 recorded from a total of ten $0.25 \mathrm{~m}^{2}$ quadrats (Table 2.1) (Braun-Blanquet. 1972; (Fourqurean et al. 2001, Fourqurean et al. 2002). The Braun Blanquet scores were used to calculate density $\left(\mathbf{D}_{\mathbf{a}}\right)$, abundance $\left(\mathbf{A}_{\mathbf{a}}\right)$, and frequency $\left(\mathbf{F}_{\mathbf{a}}\right)$ for each taxon $(\mathbf{a})$ at each site, as shown on Table 2.2.

In addition to benthic composition data, sediment type was assessed qualitatively and given a Braun Blanquet score, sediment depth $(\mathrm{cm})$ was measured by probing to bedrock in each of the ten quadrats, and water depth (ft.) was recorded as described in Chapter 2. Surface water salinity (practical salinity scale), temperature $\left({ }^{\circ} \mathrm{C}\right)$, and dissolved oxygen $\left(\mathrm{mg} \mathrm{l}^{-1}\right)$ were also measured at each site by the using a Hydrolab ${ }^{\circledR}$ Mini Sonde.

Seagrass Collection and Analysis

Leaf nutrient content and elemental ratios were analyzed for Thalassia testudinum, Halodule wrightii and Ruppia maritima at each transect site to determine relative nearshore nutrient availability for seagrasses. At each transect sampling site, 5-6 intact short shoots of T. testudinum and 25-40 intact short shoots of $H$. wrightii and $R$. maritima were haphazardly collected within $10 \mathrm{~m}$ of the site. These short shoots were stored in plastic bags, placed on ice, and transferred to the lab within 15 hours. Attached green leaves were cut from the short shoots and cleaned of adhering epiphytes by gently scraping with a razor, dried at $80^{\circ} \mathrm{C}$, and ground to a fine powder by using a ceramic 
mortal and pestle (see Fourqurean and Zieman 2002). Morphological measurements of all T. testudinum leaves (length and width) were recorded and dry weight was determined. Carbon and nitrogen contents were determined with a NA 1500 Nitrogen/Carbon Analyzer (Carlo Erba Instruments ${ }^{\mathrm{TM}}$, Fisions $1500 \mathrm{~N}$ ), which combusted the dry samples and detected the elements with a Thermo Conductivity Detector (TCD). Seagrass TP followed a dry-oxidation, acid hydrolysis extraction followed by colorimetric analysis of phosphate concentration measured on an Alpkem Rapid Flow Analyzer (EPA Method 365.1). This TP method is a modification of the method presented in (Solórzano and Sharp 1980) for particulate TP. Elemental content and ratios were calculated on a dry weight and mole: mole basis, respectively.

\section{Water Collection and Analysis}

Surface water was collected bimonthly at all 20 sites, put on ice and transported to the lab within $15 \mathrm{hrs}$ of collection as a proxy to determine available nutrients. Unfiltered water samples were analyzed for total phosphorus (TP), total nitrogen (TN), and total organic carbon (TOC). Filtered samples (acetone-washed $60 \mathrm{ml}$ bottles) were analyzed for the inorganic nutrients; nitrate + nitrite $\left(\mathrm{NO}_{\mathrm{x}}{ }^{-}\right)$, nitrite $\left(\mathrm{NO}_{2}{ }^{\circ}\right)$, and ammonium $\left(\mathrm{NH}_{4}{ }^{+}\right)$ and soluble reactive phosphorus (SRP). A calibrated Hydrolab ${ }^{\circledR}$ Mini Sonde was used to record salinity (practical salinity scale), dissolved oxygen (DO, $\mathrm{mg} \mathrm{l}^{-1}$ ), and temperature $\left({ }^{\circ} \mathrm{C}\right)$ at all water quality sampling sites.

Water TP followed the standard method similar to what was used for seagrass tissue samples. Water samples for TOC was measured by direct injection onto a hot platinum catalyst in a Shimadzu TOC-5000 (GMI, Inc., Minnesota, and MN) after being 
purged with $\mathrm{CO}_{2}$ free air and acidified. Total Nitrogen was measured by the use of an ANTEK $7000 \mathrm{~N}$ Nitrogen Analyzer (Antek, Houston, TX) that uses $\mathrm{O}_{2}$ as a carrier gas (Frankovich and Jones 1998). Filtered water samples were analyzed for inorganic nutrients $\left(\mathrm{NO}_{2}{ }^{-}, \mathrm{NH}_{4}{ }^{+}, \mathrm{SRP}\right.$, and $\mathrm{NO}_{\mathrm{x}}^{-}$) on a four-channel auto analyzer, (Alpkem model RFA 300) (SERC SOP, 2001). Concentrations of $\mathrm{NO}_{3}{ }^{-}$were calculated by subtracting $\mathrm{NO}_{2}{ }^{-}$from $\mathrm{NO}_{\mathbf{x}}{ }^{-}$

\section{Groundwater Collection and Analysis}

Groundwater discharge and nutrient concentrations were measured at all 12 seepage meter sites. Seepage meters were designed for direct measurement of groundwater discharge (Lee 1977). Seepage meters consisted of the top or bottom 15-20 $\mathrm{cm}$ of a 55-gallon steel drum. The drum ends were placed open-end down by into 10-15 cm of sediment (Cable et al. 1997). Hydraulic cement was poured around the outside perimeter to seal it, to prevent surface water from entering the meter around it lower margin when sediment depth was less than $15 \mathrm{~cm}$ (Byrne, 1999). The top of the meter was placed at a slight angle and a vent installed at the high end. When not in use, a screen was fitted snugly over the top to allow proper ventilation between samplings. Large-sized Reynolds ${ }^{\circledR}$ Oven bags (7 l) were secured with rubber bands around the vent; a small PVC pipe (10 cm length and $4 \mathrm{~cm}$ diameter) attached to PVC coupling on the meter (Figure 3.3). The bags were pre-filled with 1 liter of deionized water $\left(\mathrm{DI} \mathrm{H}_{2} \mathrm{O}\right)$ to prevent a vacuum from developing (Belanger and Montgomery 1992, Cable et al. 1997b). Sampling time ranged between 2-3 hours depending on the site-specific flow rate. In the field a 41 nalgene graduated cylinder was used to directly measure 
groundwater discharge volumes before the sample was separated into nutrient samples. Groundwater nutrient analysis used same methodology applied to surface water. Inorganic and total nutrient concentrations for groundwater seepage was processed and analyzed as described for surface water. The sample was diluted in the field with $\mathrm{DI}_{2} \mathrm{O}$ and final concentration values considered dilution.

Groundwater nutrient load (nutrient mass / area / time unit) is the product of discharge $($ flow rate $=$ volume/ area $/$ time unit), and nutrient concentration (mass/ volume). Measured water volumes collected in the 71 bag over a known time and seepage meter area $\left(0.255 \mathrm{~m}^{2}\right)$ produced a seepage discharge (flow rate) for that site, reported as $1 \mathrm{~m}^{-2}$ day ${ }^{-1}$. Individual site loads were calculated by multiplying the nutrient concentration $(\mu \mathrm{M})$ by the discharge at that site $\left(1 \mathrm{~m}^{-2}\right.$ day $\left.{ }^{-1}\right)$ producing a load value of $\mu \mathrm{mol} \mathrm{m}{ }^{-2}$ day $^{-1}$. Groundwater loads were only calculated if flow rates were $\geq 5 \mathrm{ml} \mathrm{m}^{-2}$ $\min ^{-1}$ because of increased seepage meter error at low flow rates (Cable et al. 1997b).

Nutrient loads for the entire study area were calculated on the bases of distance from shore per meter. The nutrient load data was subdivided into three layers based upon distance from shore; linear distance $0-100 \mathrm{~m}$ (100 m total) using seepage meter (SM) $50 \mathrm{~m}, 100-225 \mathrm{~m}$ (125 m total) for SM $150 \mathrm{~m}$, and $225-350 \mathrm{~m}$ (125 m total) for SM $300 \mathrm{~m}$. Load was expressed as (weight/ distance / time unit). An estimate for nutrient loads (metric tons $\mathrm{d}^{-1}$ ) was calculated for the first $350 \mathrm{~m}$ area for the entire area.

\section{Statistical Analysis}

All seagrass community composition, tissue nutrients, surface and groundwater quality data were compared among and between transects and distance from shore to 
determine spatial variation along with measurements over time to establish temporal variation. Presence and absence, density, relative abundance, and frequency of benthic macrophyte community composition were determined. Summary statistics were calculated for all parameters to characterize the four transect areas of the southwest region of Biscayne Bay. Total nitrogen for both surface water and groundwater during the first event were discarded due to abnormal results according the Laboratory Quality Assurance Plan. Taxa density values were used when comparing benthic macrophytes to other site variables. All site variables were plotted and/ or mapped over time and with distance from shore. Box-and-whisker plots and nonparametric Kruskal-Wallis and Mann-Whitney stats were used to determine significant effect of regions (transects) and distance offshore between parameters. Nonparametric Spearman's Rho Correlations were calculated to compare how mean taxa densities, seagrass tissue nutrients, surface water variables and groundwater nutrient concentrations rank orders related. Statistical tests were run using the Statistical Package for the Social Sciences (SPSS 11.1) and Sigma Plot 2001.

\section{$\underline{\text { Results }}$}

The Spatial Variation of Benthic Macrophytes

Spatial distribution of benthic macrophytes that were documented at all transect sites were representative of the survey conducted in Chapter 2. Data analysis documents both spatial variation between transects and with distance from shore for plant communities. Halodule wrightii had the greatest distribution at $90 \%$ of the stations (Table 3.1). Thalassia testudinum and Chondria sp. were present at all transects except 
at Black Point (Bla), in contrast Ruppia maritima was not present at Turkey Point (Tur). T. testudinum had greatest densities at Tur and offshore at Mowry Canal (Mow) and Fender Point (Fen). Chara sp. was present in the northern region of the study area, along the Fen and Bla transects. Anadyomene stellata and Udotea flabellum were exclusively found at Tur, while Halimeda incrassate was present at both Tur and Mow. Total density cover of $H$. wrightii decreased southward with highest densities at Fen and Bla (Figure 3.4). Chara sp. and R. maritima mean density and variability were highest at Bla (Figure 3.5). Batophora sp. density was substantially highest for Bla ( $\mathrm{Z}$ for Bla*Fen $\mathrm{p}<0.05 ; \mathrm{Z}$ for $\mathrm{Bla} * \mathrm{Mow}=-4.537, \mathrm{p}<0.001, \mathrm{Bla} *$ Tur $=-6.920, \mathrm{p}<0.001)$ (Figure 3.6) while Penicillus sp. densities were highest for Tur ( $\mathrm{Z}$ for Tur*Mow $=-5.507, \mathrm{p}<0.001 ; \mathrm{Z}$ for Tur*Fen $=-5.446 ; \mathrm{Z}$ for $\mathrm{p}<0.001 ;$ Tur*Bla $=-6.651, \mathrm{p}<0.001)$ (Figure 3.7).

Spatial differences associated with distance from shore were observed with some variability between transects. Penicillus sp. and T. testudinum mean densities were highest offshore while, H. wrightii, Chara sp. and Batophora sp. means increased inshore (Figure 3.8). Ruppia maritima mean was highest at $300-400 \mathrm{~m}$ offshore at Bla. The overall spatial pattern found with distance offshore were not the same when transects were examined individually. Turkey Point had highest mean T. testudinum and lowest Batophora sp. densities at $50 \mathrm{~m}$ and $600 \mathrm{~m}$ offshore (Figure 3.9a). Thalassia testudinum had the greatest abundance at $300 \mathrm{~m}$ offshore Mow, while $H$. wrightii and Batophora sp. hit peaks at $50 \mathrm{~m}$ offshore (Figure $3.9 \mathrm{~b}$ ). Halodule wrightii density decreased when $T$. testudinum increased offshore at Fen (Figure 3.9c). At Black Point $H$. wrightii and Batophora sp. dominated offshore at $600 \mathrm{~m}$ while $R$. maritima and Chara sp. had lowest densities offshore (Figure 3.9d). 


\section{Seagrass Nutrient Content}

Ruppia maritima and T. testudinum were not present at all transect sampling sites, therefore the leaf tissue nutrient for these species have blanks in the data set. However, more importantly mean and median percent carbon, nitrogen, and phosphorus content of H. wrightii leaves (calculated as percent dry weight) were used for analyses. All three species of seagrass mean leaf tissue nutrient concentrations are recorded by transect on Table 3.2a \& b. Mean C: N ratio for H. wrightii at Tur, Mow, Fen, and Bla were 20.0, $19.4,19.6$, and 19.0, respectively, and the mean the $\mathrm{C}: \mathrm{P}$ ratios were $1458.3,1506.7$, 1623.2 and 1083.7. A northward increase in median \% C and \% P for H. wrightii can be seen along until a sudden decrease of $\% \mathrm{P}, \mathrm{C}: \mathrm{P}$ and $\mathrm{N}$ : P ratios. Black Point had significantly higher $H$. wrightii \% $\mathrm{P}(Z<-4.75, \mathrm{p}<0.001)$ and lower $\mathrm{C}$ : $\mathrm{P}(Z<-3.939$, $\mathrm{p}<0.001$ ) than the other locations (Figure 3.10a-b). Nitrogen: Phosphorus values from Halodule wrightii increased offshore (Chi sq. 17.377, $\mathrm{p}<0.01$ ) for all transects (Figure 3.11).

Water Quality

Salinity decreased northward with lowest salinities found at Bla. Table 3.4a-b summarizes water quality values for each transect collected during the six events. Mean and median concentrations for TP, $\mathrm{NH}_{4}{ }^{+}$and TOC were highest at Bla, which also had a lower salinity value (Table 3.2b). Salinity means and median values decreased northward and were significantly $(Z<-3.1, \mathrm{p}<0.01)$ higher at Tur and lower at $\mathrm{Bla}(Z<-3.9, \mathrm{p}<0.001)$ (Figure 3.12). The data shows a gradual salinity increase offshore at Fen $\&$ Bla, while offshore Bla, TN was extremely high. Mowry Canal (Mow) had the highest mean and 
median value for surface water $\mathrm{NO}_{3}{ }^{\circ}$ and SRP, while the Fen had elevated mean DO and TN. A slight decrease of TOC offshore was found along all transects and a similar trend was observed at Bla for TP. At $600 \mathrm{~m}$ offshore of Bla, there was elevated $\mathrm{TN} \& \mathrm{NO}_{3}$. Ammonium $\left(\mathrm{NH}_{4}{ }^{+}\right)$concentrations peaked at $150 \mathrm{~m}$ offshore at Mow, Fen, and Bla.

Relationships Between Benthic Macrophytes and Nutrient Availability.

Spearman's Rho Correlation was calculated for most taxa, surface water variables and plant tissue nutrients, Table 3.3 lists all that were significant. Species density of $T$. testudinum, Halimeda sp., and Penicillus sp. which all are characteristic of marine environments, was positively correlated $(\mathrm{p}<0.01)$, while densities of the brackish environment species $H$. wrightii, R. maritima, and Chara sp. were also correlated $(p<0.001)$. Density of the three representative taxa for the marine group were negatively correlated to the three species of the brackish water group $(\mathrm{p}<0.05)$. Presence of Batophora sp., a species that can tolerate brackish waters, was positively correlated to $R$. maritima presence $(\mathrm{p}<0.05)$ and Chara $\mathrm{sp} .(\mathrm{p}<0.001)$ occurrence, and negatively related to $T$. testudinum presence $(\mathrm{p}<0.001)$. Lower salinities were significantly related to higher $\mathrm{NH}_{4}{ }^{+}, \mathrm{TP}$, and to the presence of brackish water taxa $(\mathrm{p}<0.01)$. Higher salinity waters had a positive relation to marine species and higher $H$. wrightii $\mathrm{C}$ : $\mathrm{P}(\mathrm{p}$-value $<0.05)$. Therefore, salinity had a negative association with the presence of the brackish water phosphorus taxa, TP and $\mathrm{NH}_{4}{ }^{+}$concentrations, while $H$. wrightii C: P ratios increased along with salinity $(\mathrm{p}<0.05)$. 
Groundwater Nutrient Concentrations and Discharge

Groundwater salinity, discharge rate $\left(1 \mathrm{~m}^{-2} \mathrm{~d}^{-1}\right)$, nutrient concentration $(\mu \mathrm{M})$, and nutrient load $\left(\mu \mathrm{mol} \mathrm{m} \mathrm{m}^{-2}\right)$ were obtained from seepage meters installed at the first three sites of each transect. Table 3.4 lists the summary statistics for all groundwater variables. Mean concentrations of $\mathrm{NO}_{2}^{-}$, were highest at Fen $(Z=-2.7, \mathrm{p}<0.01)$. There was a decrease in groundwater salinity northward with significant differences between Tur vs. Bla $(Z=-3.4 ; \mathrm{p}<0.001)$ and Bla vs. Mow $(Z=-2.4, \mathrm{p}<0.05)$ (Figure 3.13), similar to surface water patterns. Seepage flow rates were significantly lowest for Fen $(Z<-1.9$, $\mathrm{p}<0.5$ ) while Tur and Bla appeared to have approximately equal discharge (Figure 3.14). Table 3.4 shows that $\mathrm{NO}_{2}^{-}$, TN and TOC groundwater concentrations increase as flow rates decrease on average with each transect.

Mean groundwater discharge for all transects appear to be highest at the offshore groundwater site $(300 \mathrm{~m})$, except that Mow was highest at $150 \mathrm{~m}$ offshore and had overall maximum flow rates for the entire study area (Figure 3.15). Groundwater discharge does not appear to be driven by season (Figure 3.16). Although Mow showed elevated flow rates, concentrations for TOC and TN were low (Figure 3.17). Overall, groundwater seepage nutrient concentrations were greater and more variable than those found in surface water (Table $3.2 \& 3.4$ ).

\section{Species Dominance in Relation to Groundwater Nutrients}

Groundwater nutrient concentrations were compared to taxa and surface water variables to see if groundwater contributed to the variation in species dominance in benthic communities found in the study area. After calculating Spearman's Rho 
Correlation of mean variables for the 12-groundwater sites, some correlations were found between groundwater variables and taxa (Table 3.5). As groundwater salinity increased, so did densities for T. testudinum $(\mathrm{p}<0.01)$, Penicillus sp. $(\mathrm{p}<0.05)$ and Acanthophora sp. ( $<<0.001$ ), while there was a decreased density with $R$. maritima, and Chara sp., and Batophora sp., similar to the findings from surface water. Both R. maritima and $H$. wrightii had a positive correlation to groundwater TN, TP and TOC, while Penicillus sp. $(\mathrm{p}<0.05)$ was negatively correlated. Groundwater $\mathrm{NH}_{4}{ }^{+}$was positively correlated to $H$. wrightii $(\mathrm{p}<0.05)$, and $\mathrm{NO}_{2}{ }^{-}$concentrations $(\mathrm{p}<0.05)$ to Chara sp. Elevated concentrations of groundwater TP and TOC correlated to decreased T. testudinum density ( $p<0.05$ TOC, $\mathrm{p}<0.001$ TP) and Penicillus $\mathrm{sp} .(\mathrm{p}<0.05)$ but positively related to increased H. wrightii $(\mathrm{p}<0.05)$, R. maritima $(\mathrm{p}<0.01)$ and Batophora $\mathrm{sp} .(\mathrm{p}<0.05)($ Table 3.5).

Mean site groundwater nutrient loads $\left(\mu \mathrm{mols} \mathrm{m}^{-2} \mathrm{~d}^{-1}\right)$ did not correlate to mean plant density nor to $H$. wrightii elemental ratios. Acetabularia sp., a calcareous green algae, was the only species to correlate with groundwater nutrient loads possibly due to its significant relationship with groundwater discharge rates. Higher densities of Acetabularia sp. were found with increased groundwater TN $(\rho=0.6, p<0.05)$ and TOC $(\rho=0.57, p<0.05)$ loads. Sediment type significantly correlated to groundwater nutrient loads. When the sediment type shifts from mud to coarse grains, $\mathrm{TN}(\rho=0.92, \mathrm{p}<0.001)$, TP $(\rho=0.75, p<0.01)$, TOC $(\rho=0.82, p<0.001)$ loads increased. While TOC loads negatively correlate to sediment depth $(\rho=0.65, \mathrm{p}<0.05)$. 
Potential Nutrient Loading into the Bay via Groundwater

Transect loads were calculated by extrapolating between transects using segment loads (zone $0-100 \mathrm{~m}, 100-225 \mathrm{~m}$, and $225-350 \mathrm{~m}$ ) resulting in moles $\mathrm{m}^{-1} \mathrm{~d}^{-1}$. Groundwater nutrient load averages were calculated for each transect area (e.g. Turkey Point, etc.) out to $350 \mathrm{~m}$ offshore Figure 3.18. Total phosphorus loads were highest for the Bla region and Mow had the greatest DIN loads. Table 3.6 lists estimates total nutrient loading for the entire study area with 414 metric tons $\mathrm{yr}^{-1}$ of TN and 3.44 metric tons $\mathrm{yr}^{-1}$ of TP.

\section{Discussion}

Spatial Variation of Benthic Macrophytes

Turkey Point, the area furthest south, had a benthic community typical of marine environments, while Black Point (north) had a community dominated by brackish water tolerant species, as previously documented in Chapter 2. Thalassia testudinum was very dense offshore along with Penicillus sp. where water column salinity values were high (marine levels) along with lowered nutrient concentrations. Species that do well in brackish water such as Ruppia and Chara sp. were most abundant in the nearshore and offshore areas of Black Point while Thalassia was absent from the entire transect. Water depth for the entire Black Point area was less than $1 \mathrm{~m}$ and brackish (salinity $=10-25$ psu) out to about $700 \mathrm{~m}$. Halodule wrightii was the most common seagrass species found in the region, with greatest densities at Black Point. Chara sp. had greatest densities at 300 to $400 \mathrm{~m}$ offshore suggesting that submarine groundwater discharge is most likely a major source of freshwater offshore at Black Pont. 
Nutrient Availability and Effects on Benthic Macrophyte Communities

Overall, this study shows an increase in surface water $\mathrm{NH}_{4}{ }^{+}$and TP concentrations with decreased salinity. These findings are similar to what was found by Meeder and Boyer (2001), which documented high surface water $\mathrm{NH}_{4}{ }^{+}$around Black Point with lowered salinity. Increased levels of $\mathrm{NH}_{4}{ }^{+}$have been reported to negatively impact Thalassia testudinum seedling growth at lower salinities, while at optimum salinity ranges (30-40 psu) had no growth effect caused by increased $\mathrm{NH}_{4}{ }^{+}$in a mesocosm experiment (Kahn and Durako 2006). This suggests that freshwater coming from canal discharge and/ or submarine groundwater seepage may contain elevated $\mathrm{NH}_{4}{ }^{+}$ concentrations causing difficult conditions for T. testudinum to colonize in the Black Point area. Fourqurean et al (1995) suggested that Halodule wrightii can out compete Thalassia testudinum, which eventually becomes dominant within the community when nutrients are no longer limiting due it being a better competitor for light. Therefore the tennins colored water and increased light attenuation caused by eutrophication around Black Point could have made conditions favorable for $H$. wrightii to dominate the community.

Phosphorus can enter the environment via canal and/ or groundwater discharge. Black Point appears to have a great amount of phosphorus available due to high $\% \mathrm{P}$ in H. wrightii leaf tissue. Percent $\mathrm{P}$ was significantly related to both elevated surface and groundwater P concentrations. Elemental ratio of C:P at Black Point were lowest with high tissue $\% \mathrm{P}$ suggesting that phosphorus is readily available to plants in this area. Though, it is difficult to discern between canal and submarine groundwater discharge as the source of new phosphorus at Black Pont since surface water can be greatly impacted 
by groundwater when it is shallow $(<1 \mathrm{~m})$. Water column depth may play a major role in determining the length of time or how groundwater nutrient concentrations change water column concentrations eventually leading to affects on the benthic macrophytes community structure. Regardless of how shallow the water column was at Black Point $(<.5 \mathrm{~m})$, haloclines with higher bottom salinity were observed at tide change for half the sampling events.

\section{Other Contributing Environmental Factors}

Light is a primary control for seagrass community structure. This study did not measure light since all water column depths were $<3 \mathrm{~m}$, but water color and clarity visually darkened northward towards Black Point. Turkey Point had greatest mean salinity and lowest mean surface water $\mathrm{NH}_{4}{ }^{+}$concentrations while the opposite was found at Black Point. Freshwater entering the system appears to be coupled with increased nutrient concentrations, especially $\mathrm{NH}_{4}{ }^{+}$and TP. In areas with increased nutrients, light attenuation typically occurs, making it possible for species dominance to change due to competition for the limiting resource (e.g. light) (Fourqurean et al., 1995).

\section{Using Seepage Meters as a Proxy for Groundwater Discharge}

Seepage meters, like other field equipment, have a list of possible collection errors as mentioned in methods. Areas found with low groundwater flow may have had elevated salinity levels and/ or nutrient concentrations due to a slower recharge unlike the fast discharge sites. Increased nutrient concentrations that were found in areas with low groundwater flow rates, may be an artifact of the seepage meter, due to flow not being 
great enough to cycle at least 1 seepage meter volume per day $\left(\geq 11 \mathrm{l} \mathrm{m}^{-2} \mathrm{~d}^{-1}\right)$ (Cable et al. 1997b). One should use caution if there is water current and/ or wave action present (e.g. Shinn et al. 2002). A quantitative evaluation under a controlled environment would help eliminate concerns and make seepage meters more reliable (Shinn et al. 2003; Corbett and Cable 2003). Groundwater seepage in Florida Bay had reverse flow at tide change (Chanton et al. 2003), which was not taken into account in this study since the Mowry Canal area showed no reverse flow (Meeder et al. 1997; Byrne 1999). Groundwater can also have slower retention times (re-charge) due to sediment type, which is positively correlated to flow (the finer mud makes it harder for flow to percolate) (Table 3.4).

Seepage meters were ideal for this project due to the size of the area and its capability to collect large volumes of groundwater upwelling. Seepage meters have been used in coastal environments numerous times primarily to calculate potential groundwater seepage flow rates (Lee 1977, Giblin and Gaines 1990, Belanger and Montgomery 1992, Cable et al. 1997a, Cable et al. 1997b, Byrne 1999, Rutkowski et al. 1999). Few studies used the same discharge (seepage) sample for nutrient analysis (Giblin and Gaines 1990, Byrne 1999), but used porewater peepers instead to collect groundwater nutrient samples (Giblin and Gaines 1990, Rutkowski et al. 1999). Byrne (1999) found that the mean seepage meter nutrient concentrations were significantly higher than those obtained from shallow wells ( $3.4 \mathrm{~m}$ deep) similar to findings of this study.

Areas with low groundwater discharge were areas that had very fine sediments. Fender Point, an area with the least amount of groundwater discharge and canal runoff influence and had the greatest density of $H$. wrightii. Table 3.3 has correlation values 
calculated from the mean of all 20 -sampling sites and shows H. wrightii, R. maritima and Chara sp. correlated with muddier/ fine type sediments. Halodule had its greatest densities at Fender Point, possibly due to the increased $\mathrm{NO}_{2}{ }^{-}$concentrations. For the brackish water tolerant macrophytes, both $H$. wrightii and $R$. maritima densities correlated with increases in groundwater TP and $\mathrm{NH}_{4}{ }^{+}$while Chara sp. declined.

This work and other projects have documented numerous times that $R$. maritima and $H$. wrightii do better in environments with changing salinity and higher nutrients than does Thalassia (e.g. Powell et al., 1991). Halodule wrightii was positively correlated with groundwater $\mathrm{NH}_{4}{ }^{+}, \mathrm{TN}, \mathrm{TP}$ and TOC, but negatively associated with surface salinity and R. maritima. Ruppia maritime was negatively correlated to both surface and groundwater salinity and groundwater nutrient concentrations except for groundwater $\mathrm{NH}_{4}{ }^{+}$. Halodule wrightii and R. maritima are able to overtake T. testudinum when nutrient concentrations increased with lowered salinity (Duarte, 1995, Fourqurean \& Rutten, 2003). The ability for Halodule wrightii to dominate may be due to the elimination of its limiting recourse (nutrients) making it a better competitor as suggested with the resource ratio theory (Fourqurean et al., 1995). In addition, Chara sp. is a nutrient sink in shallow lakes and was primarily found at Fender and Black Point where water is shallow. Charophytes are able to deliver oxygen to the sediment, potentially enhancing nitrification/ denitrification (Kufel and Kufel 2002). This can then convert $\mathrm{NH}_{4}{ }^{+}$to $\mathrm{NO}_{3}{ }^{-}$allowing for higher nitrogen availability for other plant species within the community and/ or remove the excess nitrogen from the environment. 
Overview

The shoreline of Biscayne National Park, is an area that is relatively small (11 $\mathrm{km}^{2}$ ), and the coastal area goes from a brackish to marine. Black Point consistently had salinity below $25 \mathrm{psu}$, high canal discharge and high groundwater flow rates. These flow rates did not show seasonality (e.g. greater flow rates during the wet season) which can be caused by the local water management practices of south Florida. The L-31E levee controls the hydrolic head, therefore affecting the timing and flow of submarine groundwater discharge.

When individual sites were compared, more species correlated to surface water $\mathrm{NH}_{4}{ }^{+}$than did groundwater $\mathrm{NH}_{4}{ }^{+}$concentrations while TP for both surface and groundwater correlated significantly to most of the taxa found. In respect to $\mathrm{NH}_{4}^{+}$, it appears that the null hypothesis was rejected; suggesting that canal discharge is more significant in determining species dominance than groundwater. This hypothesis cannot be fully discarded due to TP in both surface and groundwater being significant to most of the taxa while Black Point (where Thalassia is absent) elemental ratios demonstrate that the area has the greatest relative availability for phosphorus. It is difficult to determine if TP concentrations from surface vs. groundwater is more significant.

Elevated $\mathrm{NH}_{4}{ }^{+}$and TP concentrations for both surface and groundwater were predominate at Black Point. The seagrass community structure was different at Black Point, in respect to species dominance, than other areas examined along the shoreline of Biscayne National Park. The increased concentrations of nutrients and timing of freshwater is influenced by two landfills and human development along the coast. A TP load of 2.55 metric tons $\mathrm{yr}^{-1}$ was estimated for the entire Black Point, which is nearly half 
of what was calculated for canal discharge for the entire southern portion of Biscayne Bay (Caccia and Boyer, in press). Therefore, groundwater loading may still be a contributing factor in determining benthic macrophyte community structure in Biscayne Bay, although individual site nutrient loads did not relate to benthic community structure. Groundwater should still be considered by managers and National Park Service when determining total maximum daily loads (TMDL's) and/ or other models for the Bay. 


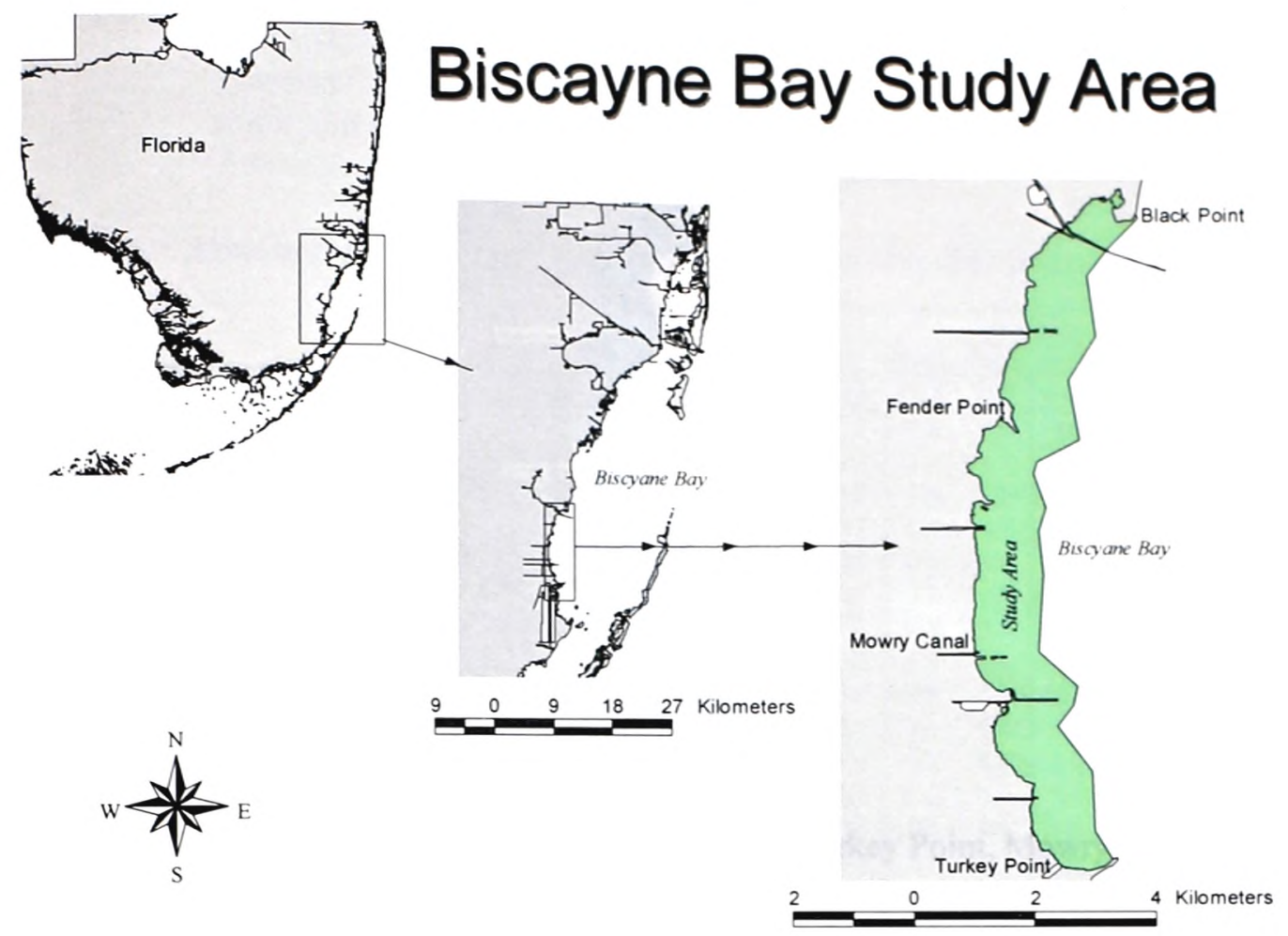

Figure 3.1. Location of study area in the southwestern portion of Biscayne Bay, Florida 


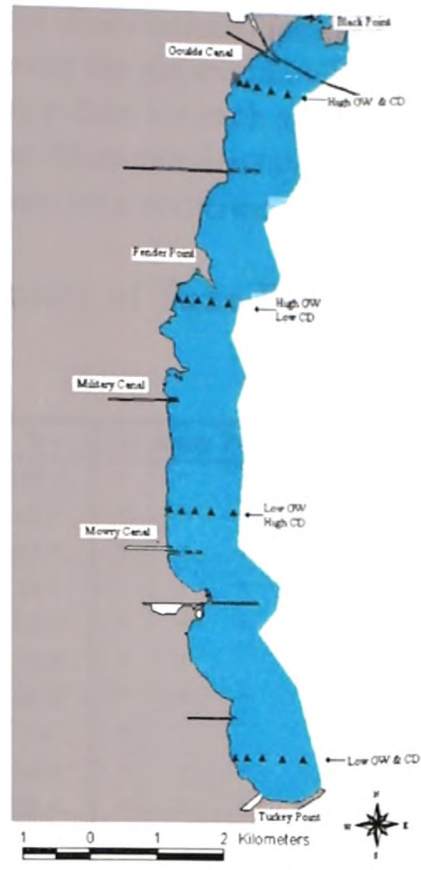

Figure 3.2. Location of transects that represent the Turkey Point, Mowry Canal, Fender Point and Back Point Vicinities.

(a)

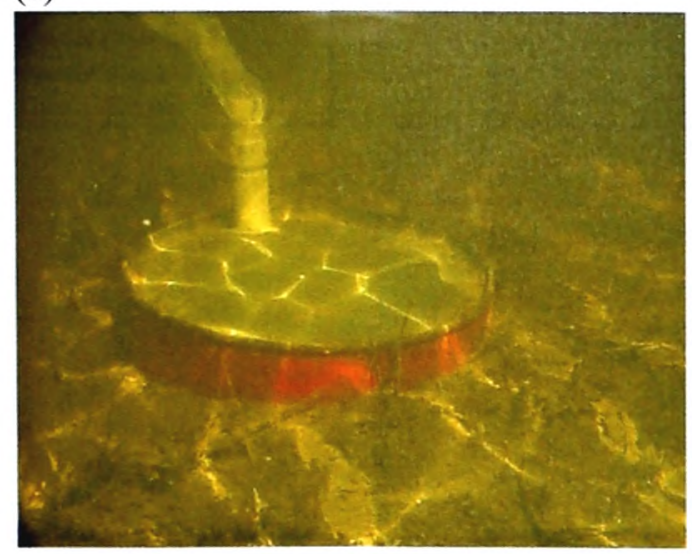

(b)

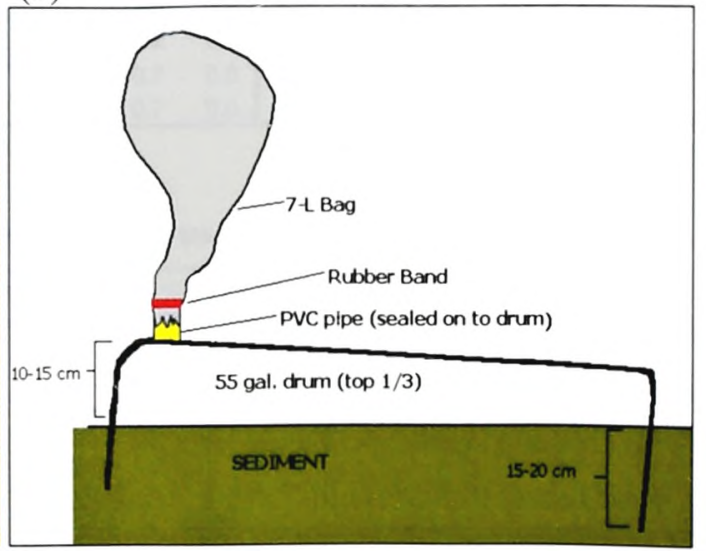

Figure 3.3. Example of a seepage meter; (a) actual meter in field and (b) schematic figure of seepage meter. 
Table 3.1. Summary of taxa distributions, including the total number and percentage of sites (20) during the six events where each taxon was present.

Presence/ absence data for each study area and the maximum and minimum Braun-Blanquet density found for each transect are listed. Asterisks indicate taxa presence within a transect.

\section{Presence/ Absence \& Density of Taxa During the Six Sampling Events}

\begin{tabular}{|c|c|c|c|c|c|c|c|c|c|c|c|c|c|c|}
\hline \multirow{3}{*}{ Taxa } & \multirow[b]{3}{*}{ \# Obsvd } & \multirow[b]{3}{*}{$\%$} & \multirow[b]{3}{*}{ Tur } & \multirow[b]{3}{*}{ Mow } & \multirow[b]{3}{*}{ Fen } & \multirow[b]{3}{*}{ Bla } & \multicolumn{8}{|c|}{ Density } \\
\hline & & & & & & & \multicolumn{2}{|c|}{ Turkey Pt. } & \multicolumn{2}{|c|}{ Mowry Canal } & \multicolumn{2}{|c|}{ Fender Pt. } & \multicolumn{2}{|c|}{ Black Pt } \\
\hline & & & & & & & $\max$ & $\min$ & $\max$ & $\min$ & $\max$ & $\min$ & $\max$ & $\min$ \\
\hline Seagrass & 108 & 100.0 & $\cdot$ & $\cdot$ & $\cdot$ & $\cdot$ & 5.0 & 1.5 & 4.5 & 2.6 & 5.0 & 1.2 & 4.7 & 1.1 \\
\hline Thalassia testudinum & 71 & 65.7 & $*$ & * & $*$ & & 5.0 & 1.5 & 4.4 & 1.1 & 3.9 & 0.0 & 0.0 & 0.0 \\
\hline Halodule wrightii & 98 & 90.7 & $*$ & $\cdot$ & * & $*$ & 1.0 & 0.0 & 3.2 & 0.2 & 3.5 & 0.1 & 3.5 & 0.0 \\
\hline Ruppia maritima & 39 & 36.1 & & • & • & • & 0.0 & 0.0 & 0.7 & 0.0 & 2.0 & 0.0 & 3.7 & 0.0 \\
\hline Calcareous Green Algae & 67 & 62.0 & $*$ & $\cdot$ & $*$ & $*$ & 1.9 & 0.0 & 0.5 & 0.0 & 1.2 & 0.0 & 0.7 & 0.0 \\
\hline Halimeda incrassata & 13 & 12.0 & $*$ & * & & & 0.5 & 0.0 & 0.3 & 0.0 & 0.0 & 0.0 & 0.0 & 0.0 \\
\hline Penicillus capitatus & 43 & 39.8 & * & • & • & & 1.6 & 0.1 & 0.3 & 0.0 & 1.3 & 0.0 & 0.0 & 0.0 \\
\hline Udotea flabellum & 2 & 1.9 & $*$ & & & & 0.1 & 0.0 & 0.0 & 0.0 & 0.0 & 0.0 & 0.0 & 0.0 \\
\hline Acetabularia crenulata & 60 & 55.6 & * & • & • & • & 1.2 & 0.0 & 0.6 & 0.0 & 0.2 & 0.0 & 0.8 & 0.0 \\
\hline Green Algae & 106 & 98.1 & $*$ & 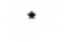 & $*$ & $*$ & 3.5 & 0.1 & 2.1 & 0.0 & 4.0 & 0.6 & 4.7 & 1.0 \\
\hline Anadyomene stellata & 7 & 6.5 & * & & & & 0.2 & 0.0 & 0.0 & 0.0 & 0.0 & 0.0 & 0.0 & 0.0 \\
\hline Genus Batophora & 106 & 98.1 & * & • & * & * & 3.2 & 0.0 & 2.0 & 0.0 & 2.4 & 0.6 & 3.9 & 0.9 \\
\hline Genus Chara & 38 & 35.2 & & & $*$ & $*$ & 0.0 & 0.0 & 0.0 & 0.0 & 2.5 & 0.0 & 3.7 & 0.0 \\
\hline Genus Chaetomorpha & 14 & 13.0 & * & * & $*$ & $*$ & 1.2 & 0.0 & 0.3 & 0.0 & 0.2 & 0.0 & 0.7 & 0.0 \\
\hline Genus Cladophora & 22 & 20.4 & * & * & * & * & 1.5 & 0.0 & 0.4 & 0.0 & 0.4 & 0.0 & 1.5 & 0.0 \\
\hline Red Algae & 94 & 87.0 & * & $*$ & * & * & 4.7 & 0.4 & 3.0 & 0.0 & 3.1 & 0.0 & 2.9 & 0.0 \\
\hline Genus Laurencia & 32 & 29.6 & * & * & 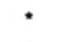 & & 3.1 & 0.0 & 1.6 & 0.0 & 0.2 & 0.0 & 0.0 & 0.0 \\
\hline Genus Acanthophora & 36 & 33.3 & $*$ & * & $*$ & $*$ & 4.5 & 0.0 & 1.2 & 0.0 & 0.8 & 0.0 & 0.1 & 0.0 \\
\hline Genus Polysiphonia & 73 & 67.6 & * & * & $*$ & $*$ & 0.6 & 0.0 & 2.4 & 0.0 & 2.7 & 0.0 & 2.9 & 0.0 \\
\hline Genus Chondria & 23 & 21.3 & * & * & * & & 1.2 & 0.0 & 1.0 & 0.0 & 0.9 & 0.0 & 0.0 & 0.0 \\
\hline Brown Algae & 10 & 9.3 & * & & $*$ & & 0.7 & 0.0 & 0.0 & 0.0 & 0.1 & 0.0 & 0.0 & 0.0 \\
\hline Genus Sargassum & 9 & 8.3 & * & & $\star$ & & 0.7 & 0.0 & 0.0 & 0.0 & 0.1 & 0.0 & 0.0 & 0.0 \\
\hline
\end{tabular}

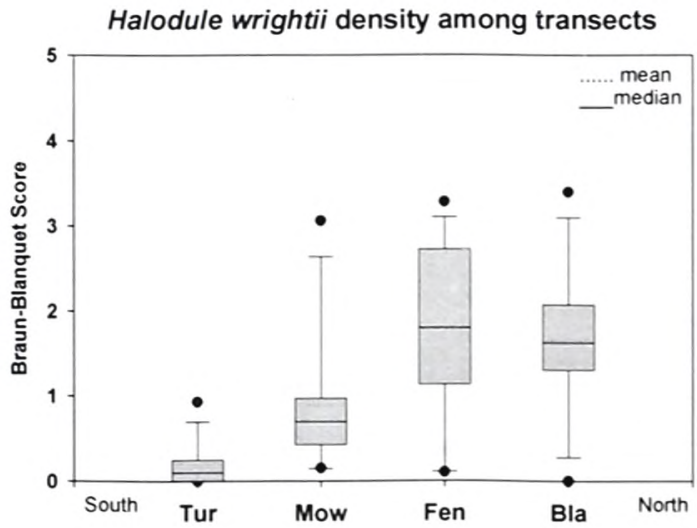

Figure 3.4. Box-and-whisker plot of Halodule wrightii showing 10 percentile. 

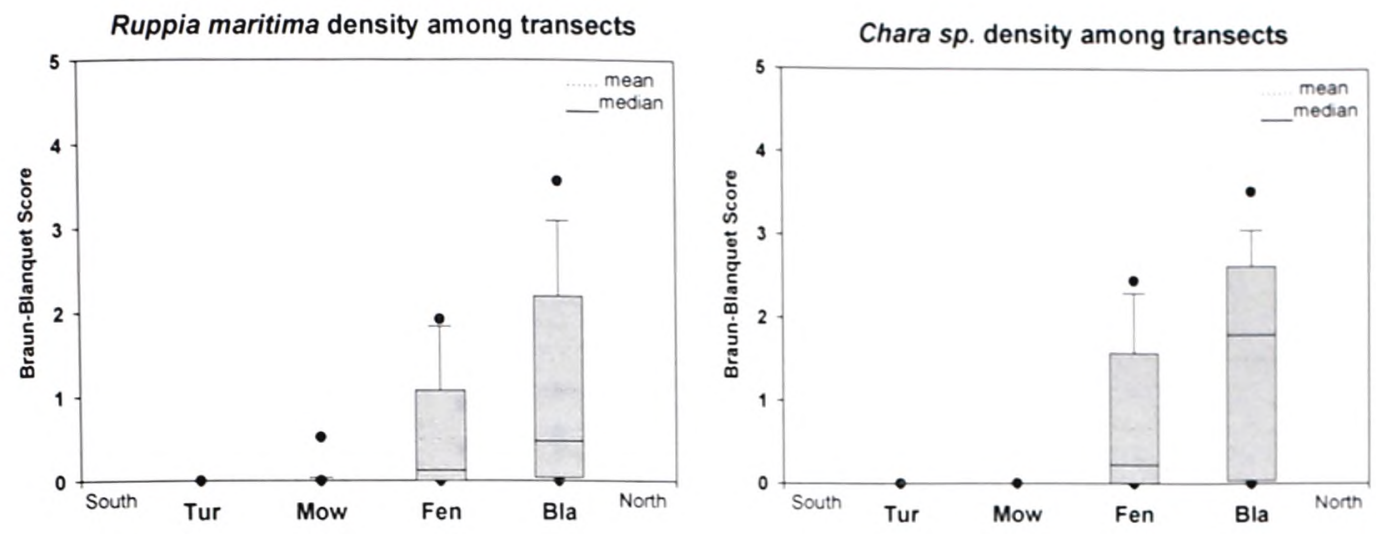

Figure 3.5. Box-and-whisker plot of Ruppia maritima and Chara sp. among study regions.

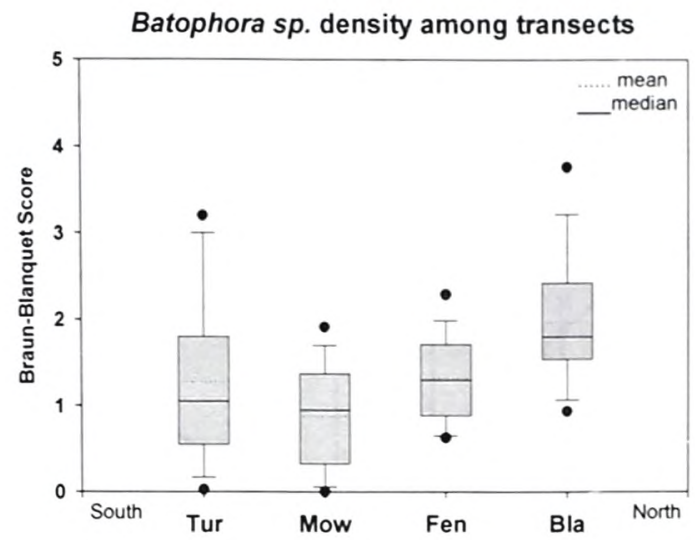

Figure 3.6. Box-and-whisker plot of Batophora sp. among study regions.

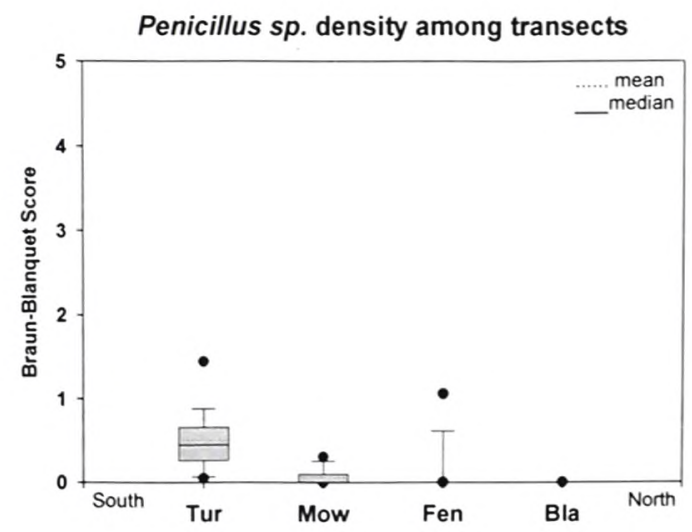

Figure 3.7. Box-and-whisker plot of Penicillus sp. among study regions. 


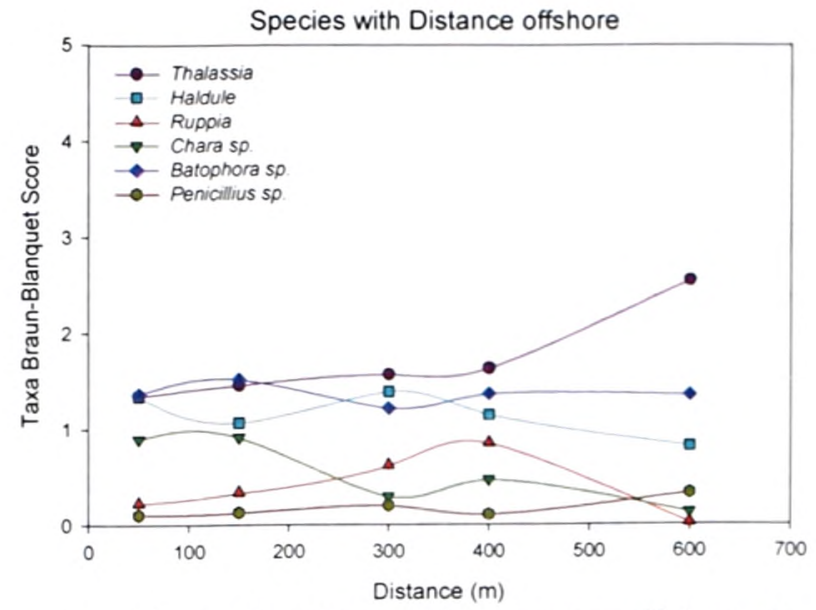

Figure 3.8. Mean macrophyte densities with distance offshore for entire area.

Data points are site means $(n=6)$

(a)

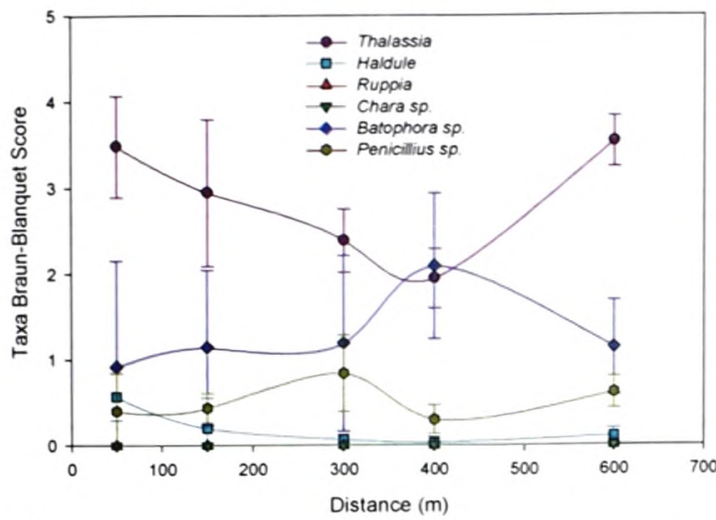

(c)

Taxa as a function of distance offshore near Fender Point

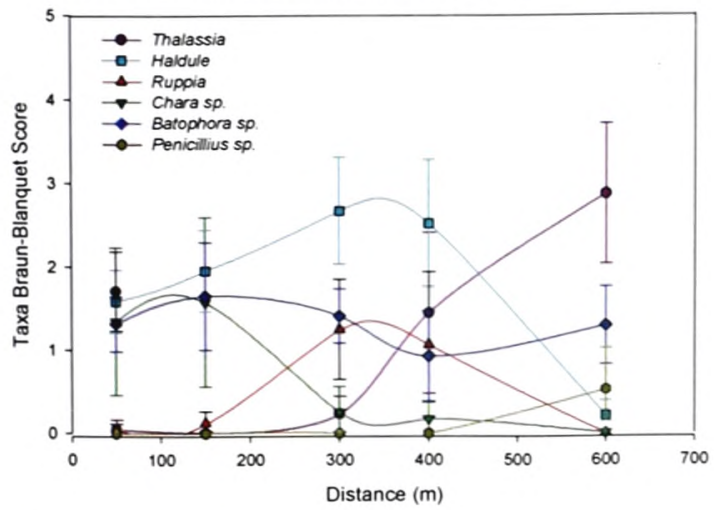

(b)

Taxa as a function to distance offshore near Mowry Canal

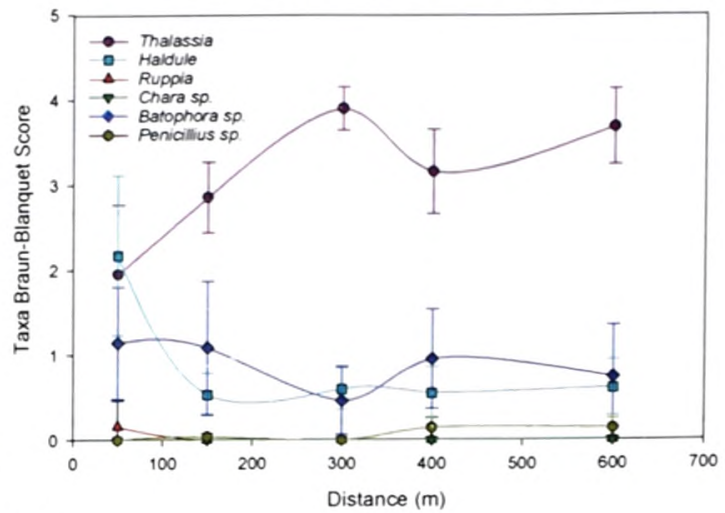

(d)

Taxa as a function of distance offshore near Black Point

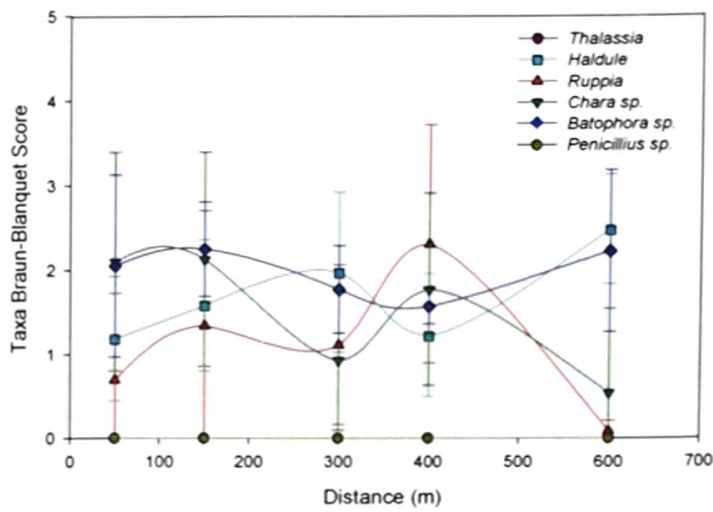

Figure 3.9. Macrophyte site means of sampling events, with distance offshore; (a) Turkey Point, (b) Mowry Canal, (c) Fender Point and (d) Black Point. Data points are site means $(n=6)$ and error bars are SD (standard deviation) 
Table 3.2a. Summary statistics of transect surface water and seagrass tissue nutrient data for Turkey Point and Mowry Canal area. (Summary continued in Table 3.3b)

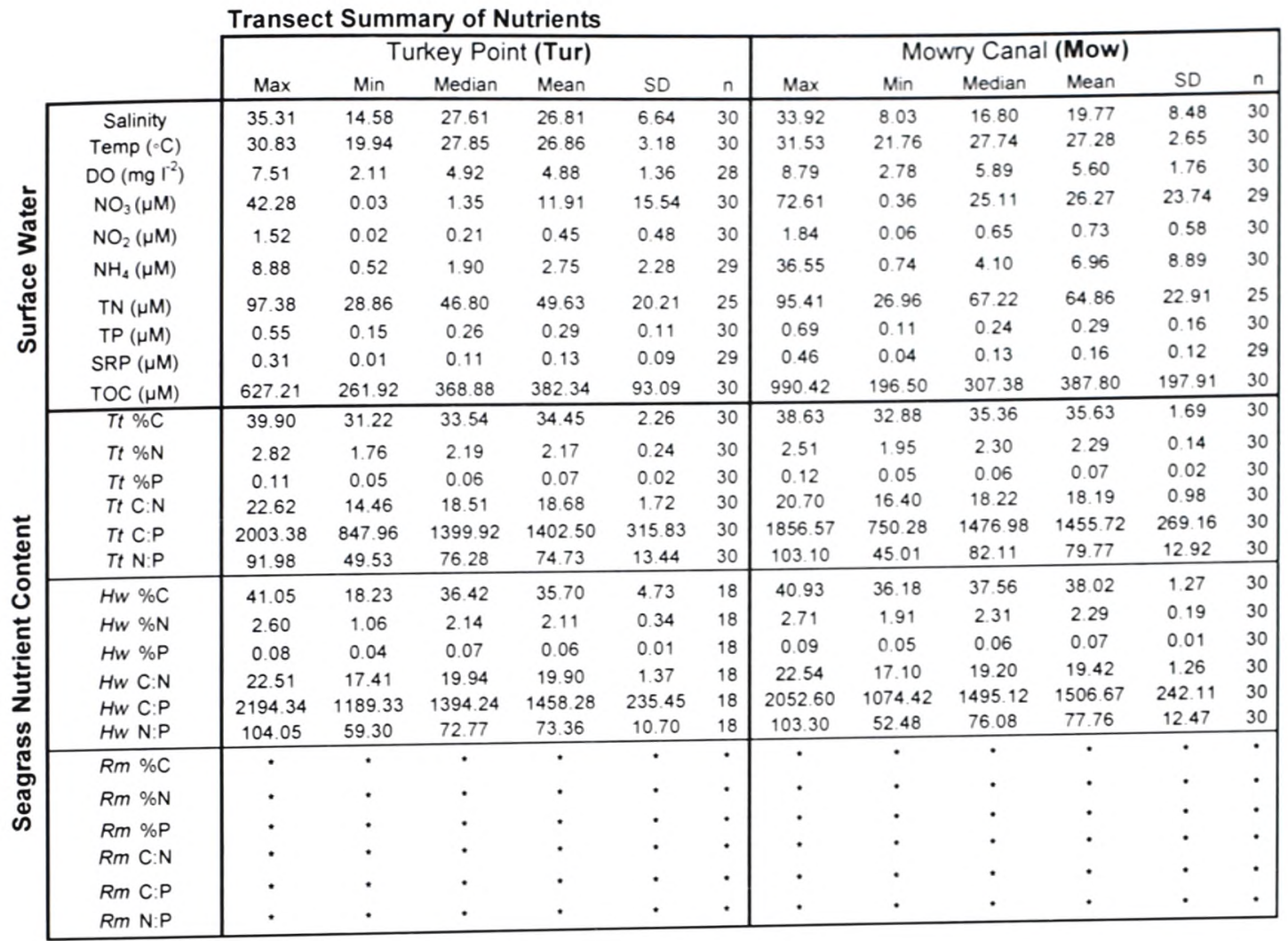


Table 3.2b. Summary statistics of water and seagrass tissue nutrient data for Fender and Black Point area (Summary continued from Table 3.3a).

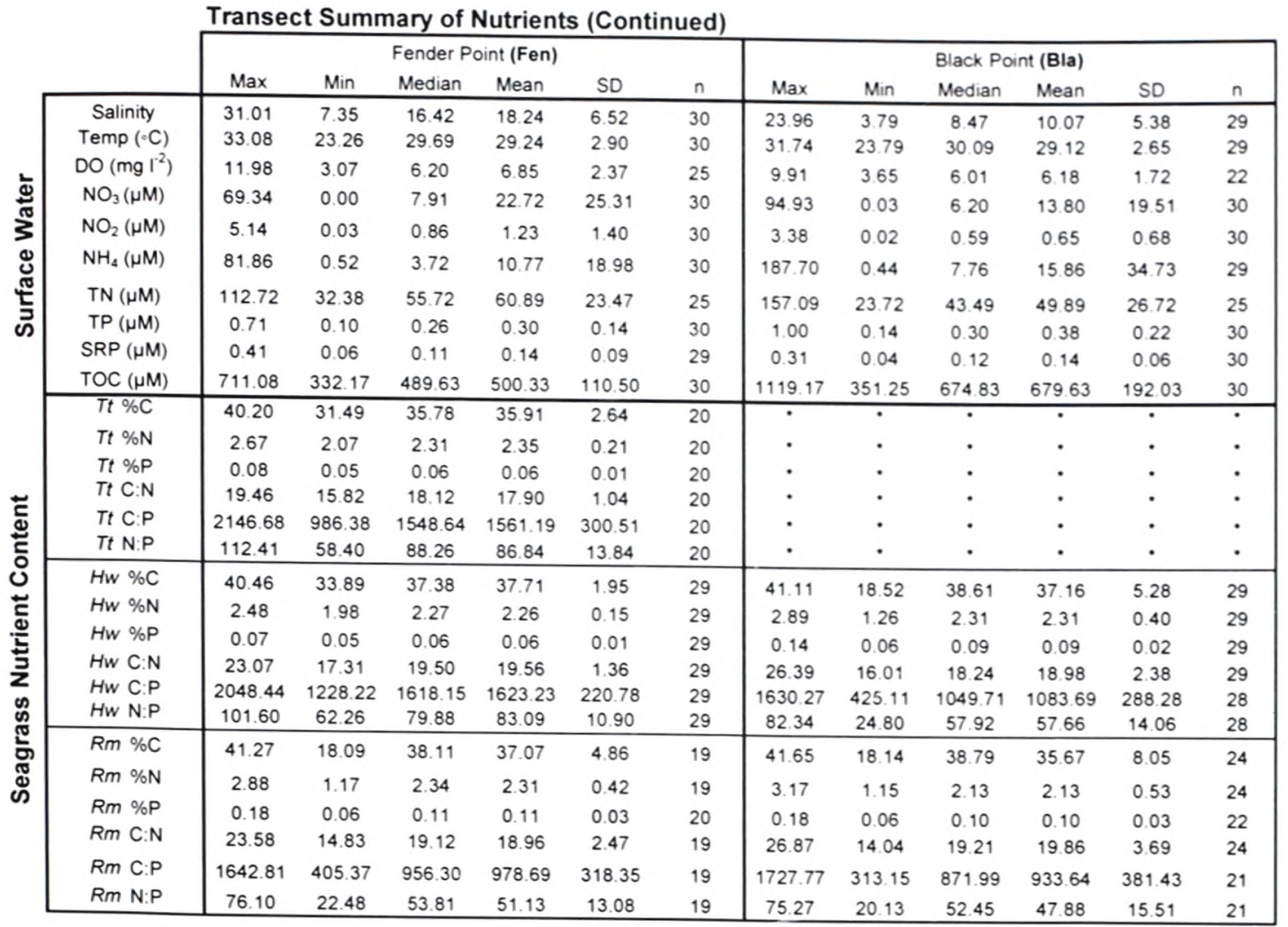

(a)

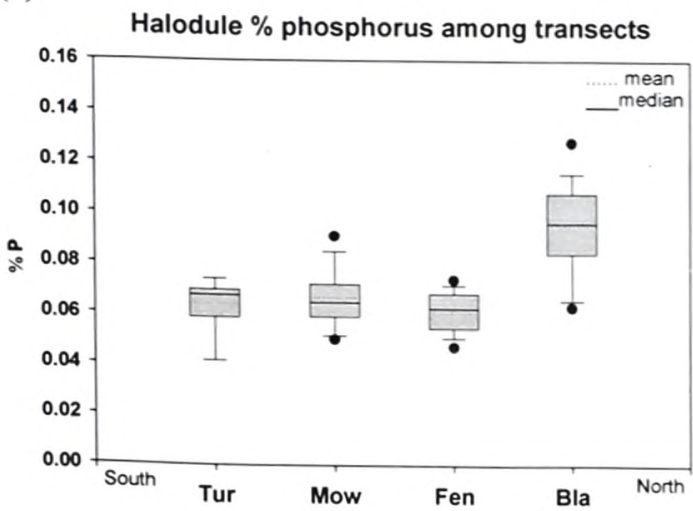

(b)

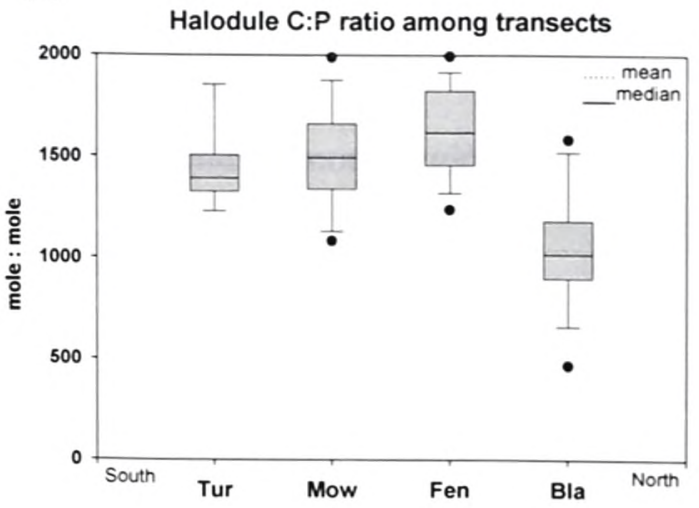

Figure 3.10. Box-and-whisker plot of Halodule wrightii; (a) \% P and (b) C: P among regions. 


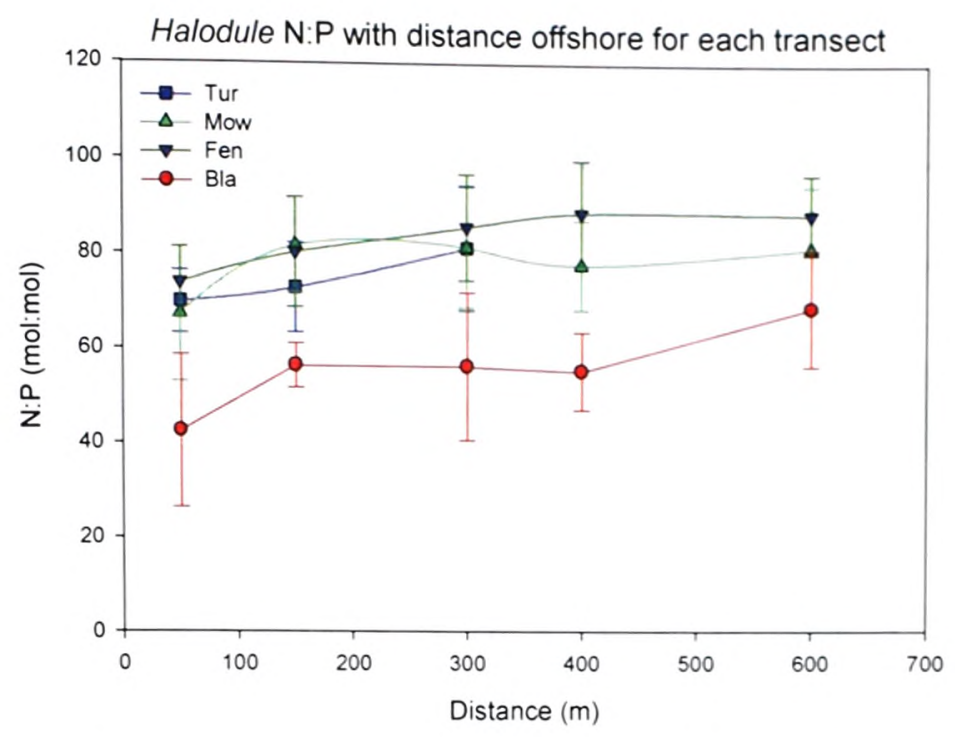

Figure 3.11. Halodule wrightii transect mean N: P ratio with distance offshore.

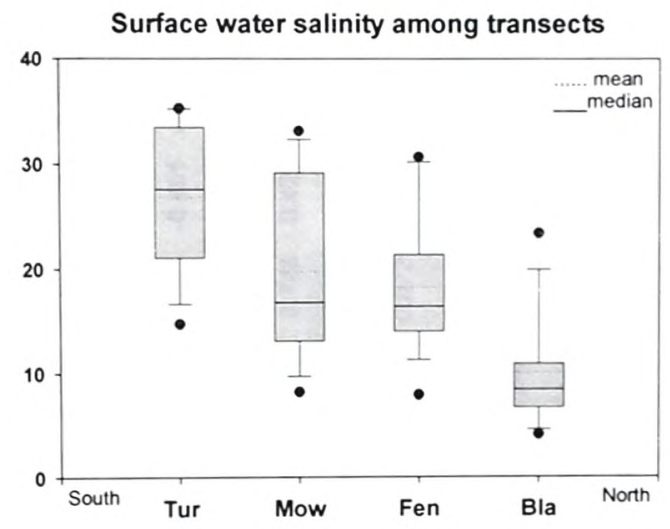

Figure 3.12. Box-and-whisker plot of surface water salinity among regions. 
Table 3.3. Spearman's Correlation Matrix with correlation coefficients (above shaded diagonal) and p-values for substrate, plant density, H. wrightii C:N:P. Based on the mean of all sampling sites $(n=20)$. Bold face above $p<0.05$.

$\left({ }^{*} p<0.05,{ }^{* *} p<0.01\right.$ and $\left.* * * p<0.001\right)$.

\begin{tabular}{|c|c|c|c|c|c|c|c|c|c|c|c|c|c|c|c|c|c|c|c|}
\hline & 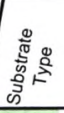 & 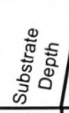 & 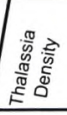 & 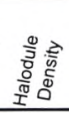 & 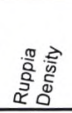 & 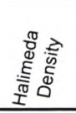 & 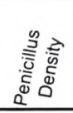 & 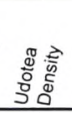 & 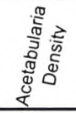 & 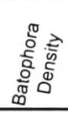 & 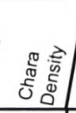 & 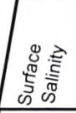 & 空 & $\stackrel{0}{\stackrel{\Xi}{\Sigma}}$ & $\begin{array}{l}\text { हू } \\
\text { है } \\
\text { है } \\
\end{array}$ & 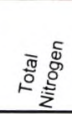 & 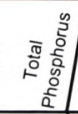 & $\mid \frac{0}{D} \geq$ & $\begin{array}{l}\frac{1}{D} \\
\frac{O}{D} \\
\frac{D}{I}\end{array}$ \\
\hline Substrate Type & & -0.552 & 0.341 & -0.543 & -0.494 & 0.268 & 0.402 & 0.522 & 0.736 & -0.151 & -0.493 & 0.309 & 0.094 & -0.294 & -0.385 & -0.137 & -0.326 & -0.204 & -0.230 \\
\hline Substrate Depth & 0.012 & & 0.265 & 0.263 & 0.135 & 0.028 & -0.077 & -0.231 & -0.592 & -0.396 & -0.133 & 0.188 & 0.074 & 0.108 & -0.180 & -0.054 & -0.021 & 0.254 & 0.333 \\
\hline Thalassia Density & 0.141 & 0.258 & & -0.578 & $\begin{array}{l}0.836 \\
-* * *\end{array}$ & 0.565 & 0.669 & 0.189 & 0.058 & -0.846 & $\begin{array}{c}* \cdots * \\
-0.881 \\
* * *\end{array}$ & 0.844 & 0.246 & -0.116 & -0.617 & -0.002 & \begin{tabular}{c|}
$* . *$ \\
-0.712
\end{tabular} & 0.352 & 0.491 \\
\hline Halodule Density & 0.013 & 0.262 & 0.008 & & 0.785 & -0.659 & -0.861 & -0.491 & -0.508 & 0.220 & $\begin{array}{l}0.611 \\
\ldots * \ldots\end{array}$ & -0.740 & 0.210 & 0.549 & 0.671 & 0.411 & 0.568 & -0.296 & 0.016 \\
\hline Ruppia Density & 0.027 & 0.570 & 0.000 & 0.000 & & -0.594 & $\begin{array}{c}-0.791 \\
* * *\end{array}$ & -0.309 & -0.344 & 0.552 & 0.844 & $\begin{array}{c}-0.857 \\
\ldots *\end{array}$ & -0.269 & 0.157 & $\begin{array}{l}0.651 \\
. \cdots\end{array}$ & -0.005 & 0.759 & -0.395 & -0.347 \\
\hline Halimeda Density & 0.253 & 0.907 & 0.009 & 0.002 & 0.006 & & 0.746 & 0.428 & 0.285 & -0.273 & -0.548 & 0.678 & -0.152 & -0.548 & $\begin{array}{c}-0.607 \\
\ldots\end{array}$ & -0.430 & $\begin{array}{c}-0.382 \\
\ldots\end{array}$ & 0.229 & -0.097 \\
\hline Penicillus Density & 0.079 & 0.746 & 0.001 & 0.000 & 0.000 & 0.000 & & 0.411 & 0.421 & -0.328 & -0.730 & 0.864 & -0.044 & -0.406 & -0.660 & -0.212 & -0.695 & 0.242 & 0.227 \\
\hline Udotea Density & 0.018 & 0.327 & 0.424 & 0.028 & 0.185 & 0.060 & 0.072 & & 0.521 & 0.145 & -0.285 & 0.376 & -0.145 & -0.246 & -0.491 & -0.333 & -0.131 & 0.258 & -0.215 \\
\hline Acetabularia Density & 0.000 & 0.006 & 0.807 & 0.022 & 0.137 & 0.222 & 0.064 & 0.018 & & 0.200 & $\begin{array}{c}-0.341 \\
* *\end{array}$ & 0.253 & -0.170 & -0.472 & -0.340 & -0.174 & -0.065 & 0.065 & -0.453 \\
\hline Batophora Density & 0.525 & 0.084 & 0.000 & 0.352 & 0.012 & 0.244 & 0.158 & 0.543 & 0.398 & & 0.692 & -0.587 & -0.295 & -0.044 & 0.333 & -0.081 & 0.528 & -0.151 & -0.541 \\
\hline Chara Density & 0.027 & 0.575 & 0.000 & 0.004 & 0.000 & 0.012 & 0.000 & 0.224 & 0.141 & 0.001 & & -0.869 & -0.305 & 0.122 & 0.711 & -0.002 & 0.681 & -0.280 & -0.414 \\
\hline Surface Salinity & 0.185 & 0.427 & 0.000 & 0.000 & 0.000 & 0.001 & 0.000 & 0.103 & 0.282 & 0.006 & 0.000 & & 0.064 & $\begin{array}{l}-0.327 \\
\ldots \ldots\end{array}$ & -0.716 & $\begin{array}{c}-0.208 \\
\ldots . .\end{array}$ & $\ddot{0.696}$ & 0.443 & 0.454 \\
\hline Nitrate & 0.695 & 0.757 & 0.297 & 0.375 & 0.251 & 0.522 & 0.852 & 0.543 & 0.474 & 0.206 & 0.190 & 0.789 & & 0.759 & 0.062 & $\begin{array}{l}0.739 \\
+\ldots\end{array}$ & -0.475 & -0.040 & 0.496 \\
\hline Nitrite & 0.209 & 0.652 & 0.627 & 0.012 & 0.508 & 0.012 & 0.076 & 0.296 & 0.036 & 0.855 & 0.609 & 0160 & 0.000 & & 0.368 & 0.780 & -0.118 & -0.076 & 0.540 \\
\hline Ammonium & 0.094 & 0.446 & 0.004 & 0.001 & 0.002 & 0.005 & 0.002 & 0.028 & 0.143 & 0.152 & 0.000 & 0.000 & 0.794 & 0.110 & & 0.405 & 0.363 & -0.393 & 0.044 \\
\hline Total Nitrogen & 0.563 & 0.821 & 0.995 & 0.072 & 0.984 & 0.059 & 0.370 & 0.152 & 0.464 & 0.736 & 0.995 & 0.378 & 0.000 & 0.000 & 0.076 & & -0.210 & -0.109 & 0.470 \\
\hline Total Phosphorus & 0.160 & 0.929 & 0.000 & 0.009 & 0.000 & 0.097 & 0.001 & 0.582 & 0.786 & 0.017 & 0.001 & 0.001 & 0.034 & 0.622 & 0.116 & 0.373 & & -0.155 & -0.670 \\
\hline Halodule C:N & 0.403 & 0.293 & 0.140 & 0.219 & 0.094 & 0.346 & 0.318 & 0.286 & 0.791 & 0.537 & 0.246 & 0.057 & 0.872 & 0.759 & 0.096 & 0.657 & 0.527 & & 085 \\
\hline Halodule C:P & 0.344 & 0.163 & 0.033 & 0.949 & 0.146 & 0.692 & 0.351 & 0.376 & 0.050 & 0.017 & 0.078 & 0.050 & 0.031 & 0.017 & 0.858 & 0.042 & 0.002 & 0.729 & \\
\hline
\end{tabular}


Table 3.4. Summary statistics of groundwater nutrient concentrations and loads for the four study areas.

\begin{tabular}{|c|c|c|c|c|c|c|c|c|c|c|c|c|}
\hline & \multicolumn{6}{|c|}{ Turkey Point (Tur) } & \multicolumn{6}{|c|}{ Mowry Canal (Mow) } \\
\hline & Max & Min & Median & Mean & SD & $n$ & Max & Min & Median & Mean & SD & $\mathrm{n}$ \\
\hline Salinity & 38.67 & 6.83 & 27.32 & 24.28 & 11.25 & 17 & 34.10 & 8.61 & 26.33 & 21.48 & 9.69 & 15 \\
\hline Surface Salinity & 35.27 & 14.58 & 27.90 & 26.88 & 7.18 & 18 & 32.38 & 8.38 & 26.48 & 23.00 & 8.67 & 15 \\
\hline Bottom Salinity & 35.50 & 19.97 & 27.89 & 27.83 & 6.17 & 18 & 33.16 & 8.38 & 27.39 & 24.65 & 8.25 & 15 \\
\hline Rate (I m-2 d-1) & 154.0 & 8.0 & 20.0 & 38.7 & 41.6 & 17 & 253.5 & 9.3 & 926 & 946 & 79.1 & 15 \\
\hline $\mathrm{NO}_{3}(\mu \mathrm{M})$ & 116.85 & 0.31 & 8.06 & 25.25 & 32.10 & 17 & 61.97 & 0.00 & 7.92 & 20.06 & 21.90 & 15 \\
\hline $\mathrm{NO}_{2}(\mu \mathrm{M})$ & 1.88 & 0.03 & 0.49 & 0.64 & 0.58 & 17 & 1.39 & 0.06 & 0.25 & 0.41 & 0.40 & 15 \\
\hline $\mathrm{NH}_{4}(\mu \mathrm{M})$ & 411.94 & 7.83 & 52.32 & 83.30 & 98.74 & 17 & 1089.09 & 7.92 & 66.80 & 198.08 & 290.05 & 15 \\
\hline $\mathrm{TN}(\mu \mathrm{M})$ & 727.38 & 76.82 & 270.55 & 294.30 & 182.19 & 15 & 347.69 & 63.34 & 159.34 & 176.30 & 104.96 & 12 \\
\hline TP $(\mu \mathrm{M})$ & 1.48 & 0.18 & 0.33 & 0.53 & 0.39 & 17 & 3.63 & 0.18 & 0.43 & 0.94 & 1.05 & 15 \\
\hline $\operatorname{SRP}(\mu \mathrm{M})$ & 1.33 & 0.15 & 0.37 & 0.50 & 0.33 & 17 & 2.53 & 0.13 & 0.28 & 0.63 & 0.69 & 15 \\
\hline TOC $(\mu \mathrm{M})$ & 8832.86 & 811.66 & 2920.56 & 3470.07 & 2323.19 & 17 & 14006.25 & 446.70 & 1062.50 & 2172.62 & 3376.22 & 15 \\
\hline $\mathrm{NO}_{3}$ (load) $)^{*}$ & 2931.2 & 4.7 & 220.5 & 671.0 & 865.5 & 17 & 11644.8 & 0.7 & 705.3 & 1755.6 & 3027.9 & 15 \\
\hline $\mathrm{NO}_{2}$ (load) $)^{*}$ & 61.9 & 2.3 & 7.6 & 15.6 & 17.3 & 17 & 128.3 & 1.9 & 21.8 & 30.9 & 34.8 & 15 \\
\hline $\mathrm{NH}_{4}(\text { load })^{*}$ & 25696.7 & 111.2 & 1133.6 & 3614.4 & 6655.1 & 17 & 64403.1 & 177.0 & 7990.2 & 12485.8 & 16510.2 & 15 \\
\hline TN (load) ${ }^{*}$ & 11961.7 & 3646.9 & 6059.5 & 6364.9 & 2519.3 & 15 & 21900.7 & 2933.3 & 8898.1 & 10332.3 & 5183.3 & 12 \\
\hline TP (load) ${ }^{*}$ & 56.4 & 1.7 & 9.2 & 16.7 & 16.4 & 17 & 137.4 & 5.1 & 48.6 & 51.4 & 38.3 & 15 \\
\hline SRP (load)* & 81.5 & 3.4 & 6.6 & 17.5 & 21.7 & 17 & 122.6 & 30 & 29.8 & 37.8 & 35.2 & 15 \\
\hline TOC (load) ${ }^{\circ}$ & 125794.4 & 40555.4 & 71962.8 & 73646.4 & 26065.0 & 17 & 202702.7 & 15751.9 & 75269.5 & 95394.3 & 51491.6 & 15 \\
\hline
\end{tabular}

*load $=\mu \mathrm{mol} \mathrm{m} \mathrm{m}^{-2} \mathrm{~d}^{-1}$

Transect Summary of Groundwater Nutrients (Continued)

\begin{tabular}{|c|c|c|c|c|c|c|c|c|c|c|c|c|}
\hline & \multicolumn{6}{|c|}{ Fender Point (Fen) } & \multicolumn{6}{|c|}{ Black Point (Bla) } \\
\hline & $\operatorname{Max}$ & Min & Median & Mean & SD & $n$ & Max & Min & Median & Mean & SD & $\mathrm{n}$ \\
\hline Salinity & 31.72 & 0.02 & 15.44 & 16.37 & 10.65 & 13 & 30.89 & 4.05 & 8.72 & 11.78 & 8.30 & 13 \\
\hline Surface Salinity & 30.25 & 7.35 & 16.43 & 18.27 & 7.62 & 13 & 22.77 & 2.00 & 8.99 & 11.19 & 6.16 & 13 \\
\hline Bottom Salinity & 30.24 & 7.78 & 16.43 & 18.44 & 7.46 & 13 & 22.79 & 2.42 & 14.53 & 12.92 & 6.16 & 13 \\
\hline Rate $(1 \mathrm{~m}-2 \mathrm{~d}-1)$ & 57.3 & 7.9 & 11.1 & 14.5 & 13.2 & 13 & 125.2 & 8.8 & 29.4 & 40.9 & 36.2 & 13 \\
\hline $\mathrm{NO}_{3}(\mu \mathrm{M})$ & 121.64 & 3.84 & 24.58 & 32.23 & 32.46 & 13 & 318.02 & 1.91 & 18.20 & 39.14 & 84.58 & 13 \\
\hline $\mathrm{NO}_{2}(\mu \mathrm{M})$ & 2.70 & 0.11 & 1.21 & 1.24 & 0.91 & 13 & 17.00 & 0.03 & 0.78 & 3.18 & 5.52 & 18 \\
\hline $\mathrm{NH}_{4}(\mu \mathrm{M})$ & 822.16 & 14.83 & 232.58 & 305.98 & 282.74 & 13 & 466.28 & 4.79 & 26.86 & 92.52 & 142.38 & 11 \\
\hline $\mathrm{TN}(\mu \mathrm{M})$ & 858.00 & 126.07 & 529.69 & 536.44 & 205.77 & 12 & 789.36 & 91.12 & 282.82 & 345.41 & 248.50 & 10 \\
\hline $\mathrm{TP}(\mu \mathrm{M})$ & 4.75 & 0.31 & 0.80 & 1.26 & 1.34 & 13 & 50.62 & 0.19 & 0.58 & 4.60 & 13.84 & 13 \\
\hline $\operatorname{SRP}(\mu \mathrm{M})$ & 4.19 & 0.27 & 0.50 & 0.82 & 1.05 & 13 & 29.57 & 0.12 & 0.29 & 2.68 & 8.09 & 13 \\
\hline $\mathrm{TOC}(\mu \mathrm{M})$ & 10703.33 & 0.00 & 6137.50 & 6044.62 & 3362.59 & 13 & 10706.94 & 1253.28 & 3447.50 & 4542.40 & 3446.49 & 13 \\
\hline $\mathrm{NO}_{3}$ (load)* & 3951.2 & 44.9 & 217.3 & 579.0 & 1049.5 & 13 & 39805.2 & 42.0 & 364.9 & 3595.2 & 10905.8 & 13 \\
\hline $\mathrm{NO}_{2}$ (load) ${ }^{*}$ & 96.6 & 1.1 & 15.1 & 19.4 & 25.3 & 13 & 25.2 & 2.3 & 13.4 & 12.4 & 8.4 & 12 \\
\hline $\mathrm{NH}_{4}$ (load) & 7265.6 & 222.5 & 2864.8 & 3155.9 & 2614.4 & 13 & 5347.4 & 206.7 & 945.0 & 1635.3 & 1716.2 & 11 \\
\hline TN (load) & 10024.6 & 3020.6 & 6555.8 & 6318.2 & 1947.3 & 12 & 16630.0 & 3419.1 & 7809.7 & 9233.4 & 4337.3 & 10 \\
\hline TP (load) ${ }^{*}$ & 40.9 & 2.8 & 10.2 & 13.9 & 11.2 & 13 & 6336.3 & 3.0 & 19.2 & 503.7 & 1752.5 & 13 \\
\hline SRP (load) ${ }^{*}$ & 36.2 & 3.0 & 5.3 & 9.1 & 9.1 & 13 & 3700.7 & 2.3 & 9.4 & 295.7 & 1023.1 & 13 \\
\hline TOC (load) ${ }^{*}$ & 125053.1 & 37630.3 & 66663.3 & 71944.4 & 24820.2 & 12 & 207108.9 & 54833.3 & 128052.3 & 114145.0 & 58903.1 & 13 \\
\hline
\end{tabular}

*load $=\mu \mathrm{mol} \mathrm{m} \mathrm{m}^{-2} \mathrm{~d}^{-1}$ 


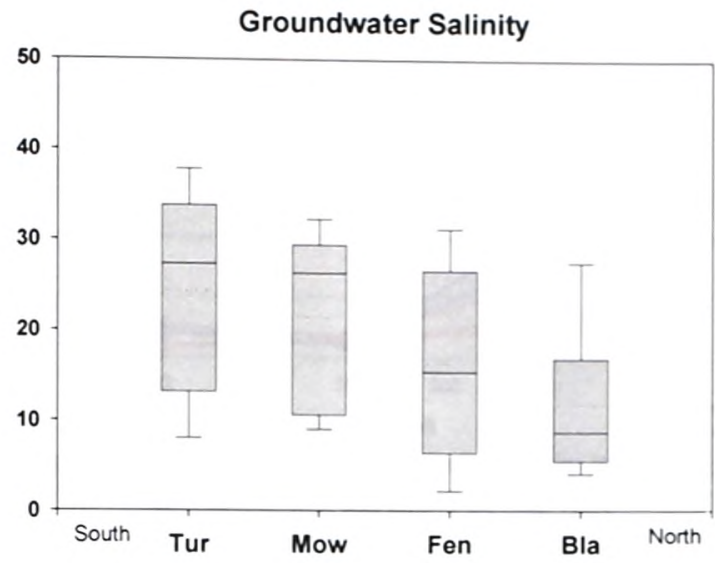

Figure 3.13. Box-and-whisker plot of groundwater salinity among study regions.

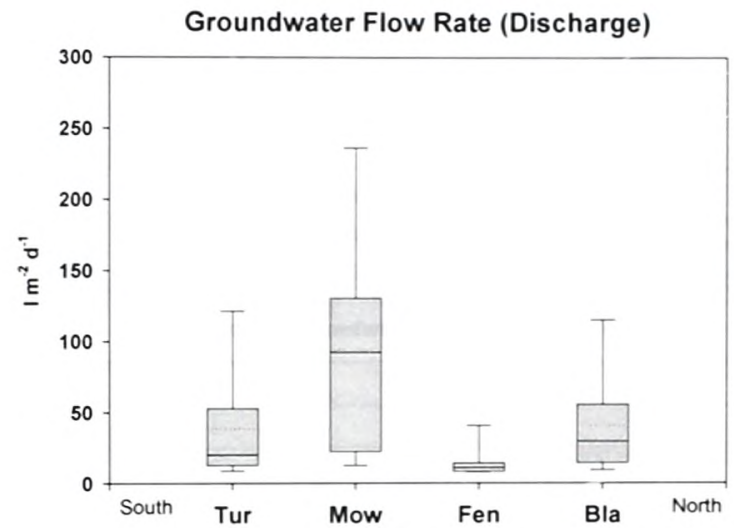

Figure 3.14. Box-and-whisker plot of groundwater flow rates among study regions.

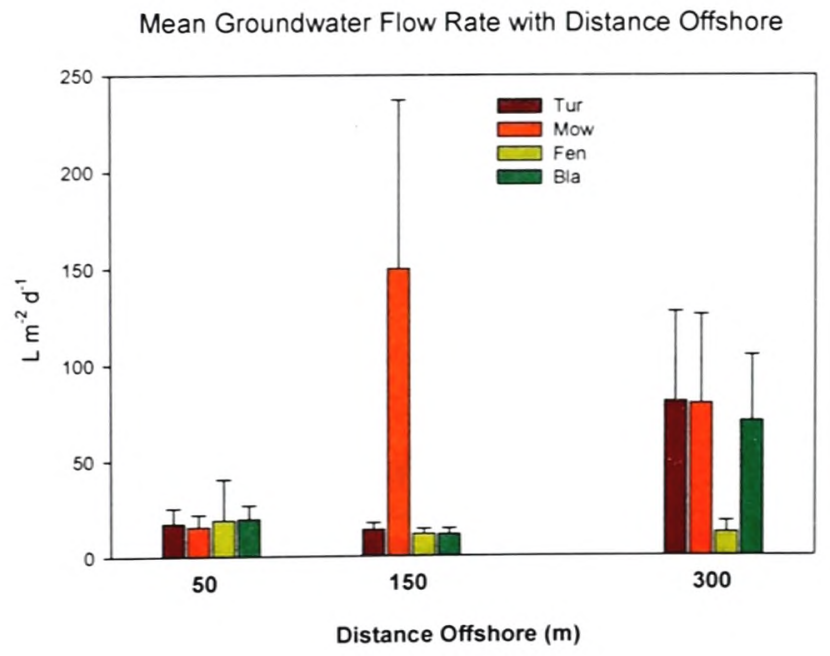

Figure 3.15. Mean groundwater flow rates $\left(1 \mathrm{~m}^{-2} \mathrm{~d}^{-1}\right)$ with distance $(\mathrm{m})$ offshore. 
(a)
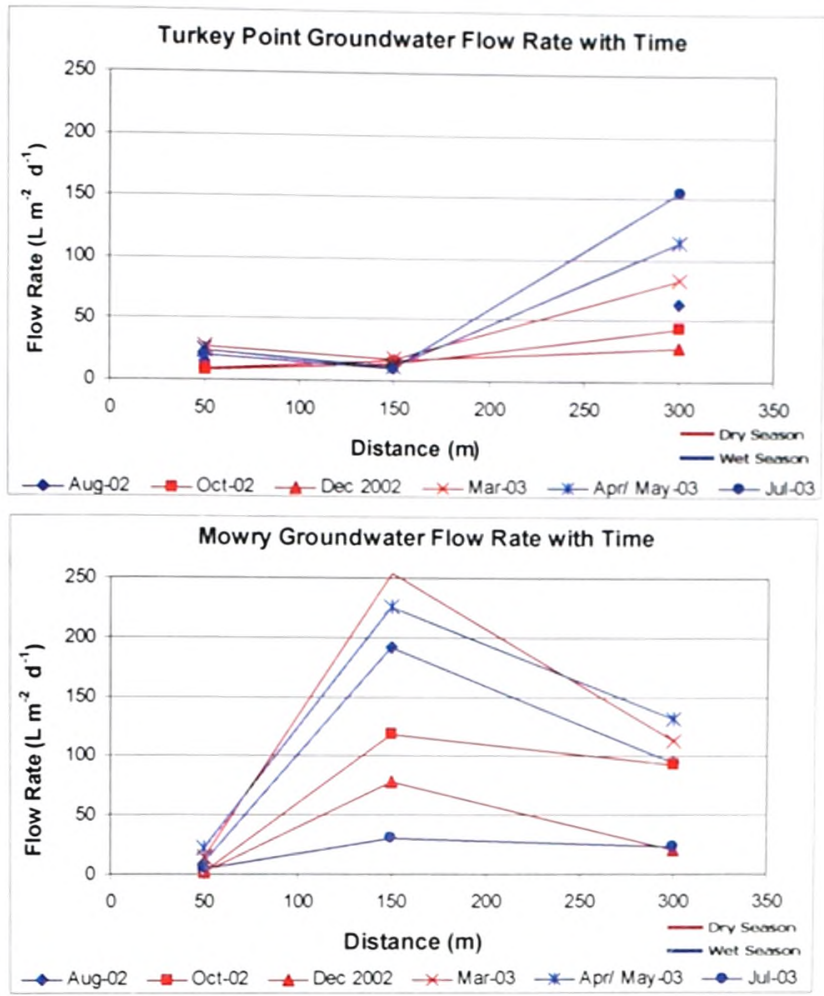

(b)

(c.)
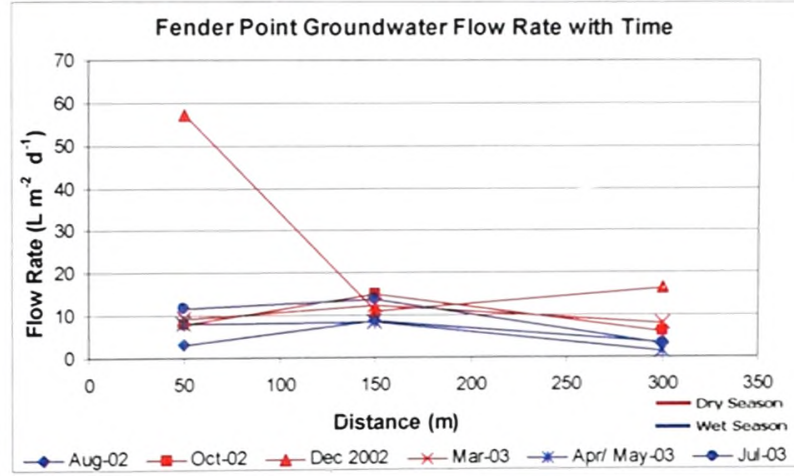

(d)

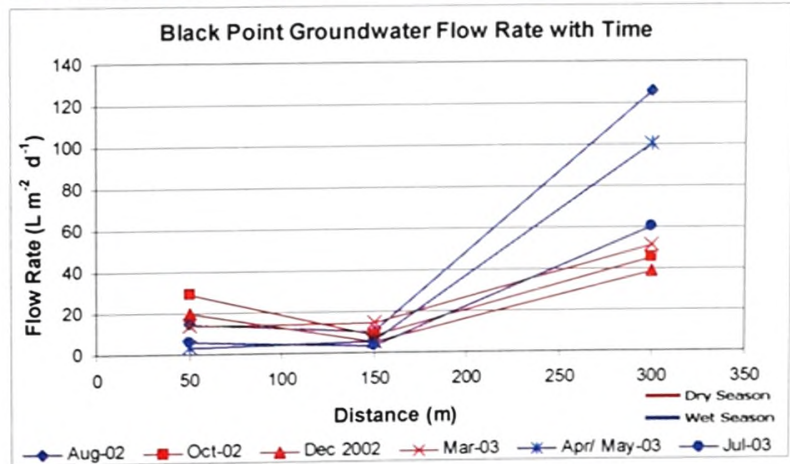

Figure 3.16. Groundwater discharge rates in time for each transect (a-Tur, b-Mow, cFen, and d-Bla). 
Mean Groundwater Total Nitrogen Concentration with Distance Offshore

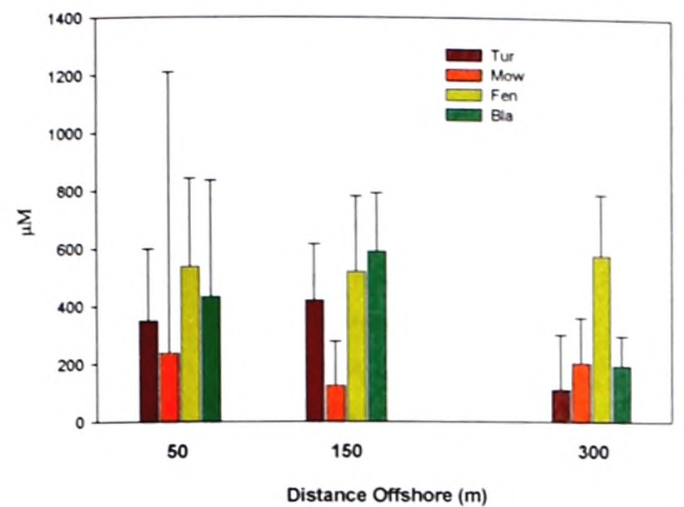

Mean Groundwater TOC Concentration with Distance Offshore

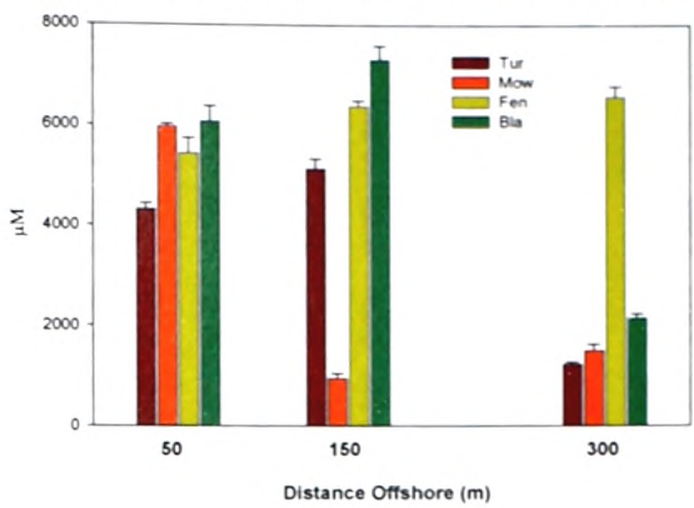

Figure 3.17. Groundwater total nitrogen and total organic carbon concentrations $(\mu \mathrm{M})$ with distance $(m)$ offshore. 
Table 3.5. Spearman's Correlation Matrix with correlation coefficients (above shaded diagonal) and p-values for mean substrate type, plant density, surface water quality and groundwater variables. Bold face above $p<0.05$. Based on groundwater sites only $(\mathrm{n}=12)$.

$\left({ }^{*} \mathrm{p}<0.05, * * \mathrm{p}<0.01\right.$ and $\left.\mathrm{d}^{* * *} \mathrm{p}<0.001\right)$. Rate $\left(1 \mathrm{~m}^{-2} \mathrm{~d}^{-1}\right)$

\begin{tabular}{|c|c|c|c|c|c|c|c|c|c|c|c|c|c|c|c|c|c|c|c|}
\hline & 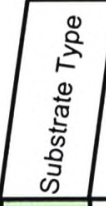 & 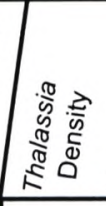 & 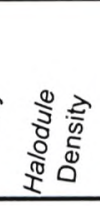 & 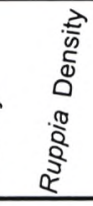 & 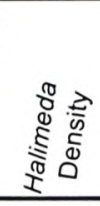 & 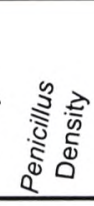 & 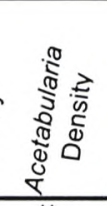 & 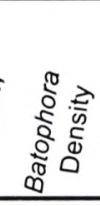 & $\begin{array}{r}\frac{1}{0} \\
0 \\
0 \\
0 \\
0 \\
0 \\
0 \\
0 \\
0\end{array}$ & 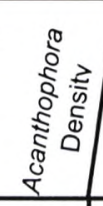 & 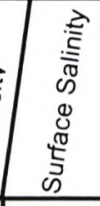 & 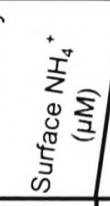 & 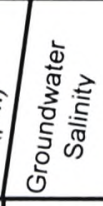 & 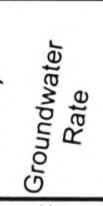 & 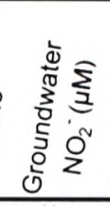 & 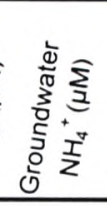 & 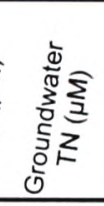 & 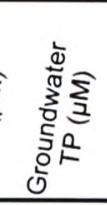 & 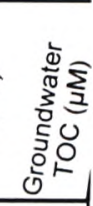 \\
\hline Substrate Type & & 0.145 & -0.368 & -0.258 & -0.129 & 0.167 & 0.738 & -0.261 & -0.372 & 0.180 & 0.161 & -0.119 & 0.102 & 0.718 & -0.758 & -0.417 & -0.564 & -0.354 & -0.669 \\
\hline Thalassia Density & 0.654 & & -0.549 & -0.840 & 0.619 & 0.633 & -0.064 & -0.956 & -0.891 & 0.733 & 0.894 & -0.908 & 0.796 & 0.303 & -0.303 & -0.197 & -0.430 & -0.674 & -0.577 \\
\hline Halodule Density & 0.240 & 0.064 & & 0.776 & -0.661 & -0.832 & -0.344 & 0.438 & 0.448 & -0.610 & -0.650 & 0.601 & -0.364 & -0.476 & 0.053 & 0.608 & 0.622 & 0.851 & 0.622 \\
\hline Ruppia Density & 0.418 & 0.001 & 0.003 & & -0.600 & -0.725 & -0.095 & 0.832 & 0.755 & -0.573 & -0.848 & 0.819 & -0.631 & -0.544 & 0.163 & 0.457 & 0.587 & 0.712 & 0.769 \\
\hline Halimeda Density & 0.690 & 0.032 & 0.019 & 0.039 & & 0.863 & 0.060 & -0.423 & -0.529 & 0.739 & 0.725 & -0.762 & 0.569 & 0.037 & 0.009 & -0.477 & -0.321 & -0.432 & -0.330 \\
\hline Penicillus Density & 0.605 & 0.027 & 0.001 & 0.008 & 0.000 & & 0.361 & -0.477 & -0.640 & 0.857 & 0.803 & -0.732 & 0.632 & 0.329 & -0.177 & -0.582 & -0.591 & -0.592 & -0.582 \\
\hline Acetabularia Density & 0.006 & 0.844 & 0.274 & 0.770 & 0.853 & 0.249 & & -0.004 & -0.258 & 0.317 & 0.060 & $\begin{array}{l}-0.105 \\
\ldots .\end{array}$ & 0.172 & 0.593 & -0.661 & -0.558 & -0.470 & -0.088 & -0.53 \\
\hline Batophora Density & 0.412 & 0.000 & 0.155 & 0.001 & 0.171 & 0.117 & 0.991 & & 0.901 & -0.589 & -0.806 & 0.851 & -0.767 & -0.431 & 0.419 & 0.179 & 0.431 & 0.584 & 0.658 \\
\hline Chara Density & 0.234 & 0.000 & 0.144 & 0.005 & 0.077 & 0.025 & 0.417 & 0.000 & & -0.782 & -0.885 & 0.885 & -0.877 & -0.470 & 0.604 & 0.280 & 0.523 & 0.479 & 0.713 \\
\hline Acanthophora Density & 0.575 & 0.007 & 0.035 & 0.050 & 0.006 & 0.000 & 0.316 & 0.044 & 0.003 & & 0.842 & -0.774 & 0.849 & 0.168 & -0.348 & -0.232 & -0.392 & -0.550 & -0.42 \\
\hline Surface Salinity & 0.617 & 0.000 & 0.022 & 0.000 & 0.008 & 0.002 & 0.854 & 0.002 & 0.000 & 0.001 & & -0.909 & 0.846 & 0.343 & -0.238 & -0.231 & -0.462 & -0.620 & -0.594 \\
\hline Surface $\mathrm{NH}_{4}{ }^{\prime}(\mu \mathrm{M})$ & \begin{tabular}{|l|l|} 
\\
\end{tabular} & 0.000 & 0.039 & 0.001 & 0.004 & 0.007 & 0.745 & 0.000 & 0.000 & 0.003 & 0.000 & & $-0 . \ddot{8} 25$ & -0.378 & 0.287 & 0.336 & 0.434 & 0.574 & 0.601 \\
\hline Gro & 53 & 002 & 245 & 0.028 & 0.053 & 0.027 & 593 & 004 & 0.000 & 0.000 & 001 & 0.001 & & 0.182 & -0.371 & 0.000 & -0.196 & -0.340 & -0.434 \\
\hline Groundwater Rate & 0.009 & 0.339 & 0.118 & 0.068 & 0.910 & 0.297 & 0.042 & 0.162 & 0.123 & 0.603 & 0.276 & 0.226 & 0.572 & & -0.585 & -0.545 & -0.790 & -0.385 & -0.888 \\
\hline Groundwater $\mathrm{NO}_{2}^{-}(\mu \mathrm{M})$ & 0.004 & 0.338 & 0.871 & 0.612 & 0.977 & 0.582 & 0.019 & 0.175 & 0.038 & 0.267 & 0.456 & 0.365 & 0.235 & 0.046 & & 0.340 & 0.550 & 0.072 & 0.644 \\
\hline Groundwater $\mathrm{NH}_{4}{ }^{\top}(\mu \mathrm{M})$ & 0.178 & 539 & 0.036 & 0.135 & 0.117 & 0.047 & 0.059 & 0.579 & 0.378 & 0.469 & 0.471 & 0.286 & 1.000 & 0.067 & 0.280 & & $0 . \ddot{741}$ & 0.326 & 0.678 \\
\hline Groundwater TN $(\mu \mathrm{M})$ & 0.056 & 0.163 & 0.031 & 0.045 & 0.309 & 0.043 & 0.123 & 0.162 & 0.081 & 0.207 & 0.131 & 0.159 & 0.542 & 0.002 & 0.064 & 0.006 & & 0.553 & 0.881 \\
\hline Groundwater TP $(\mu \mathrm{M})$ & 0.258 & 0.016 & 000 & 0.009 & 0.161 & 0.043 & 0.786 & 0.046 & 0.116 & 0.064 & 0.032 & 0.050 & 0.280 & 0.216 & 0.824 & 0.301 & 0.062 & & 0.508 \\
\hline Groundwater TOC $(\mu \mathrm{M})$ & 0.017 & 0.049 & 0.031 & 0.003 & 0.294 & 0.047 & 0.074 & 0.020 & 0.009 & 0.169 & 0.042 & 0.039 & 0.159 & 0.000 & 0.024 & 0.015 & 0.000 & 0.092 & \\
\hline
\end{tabular}




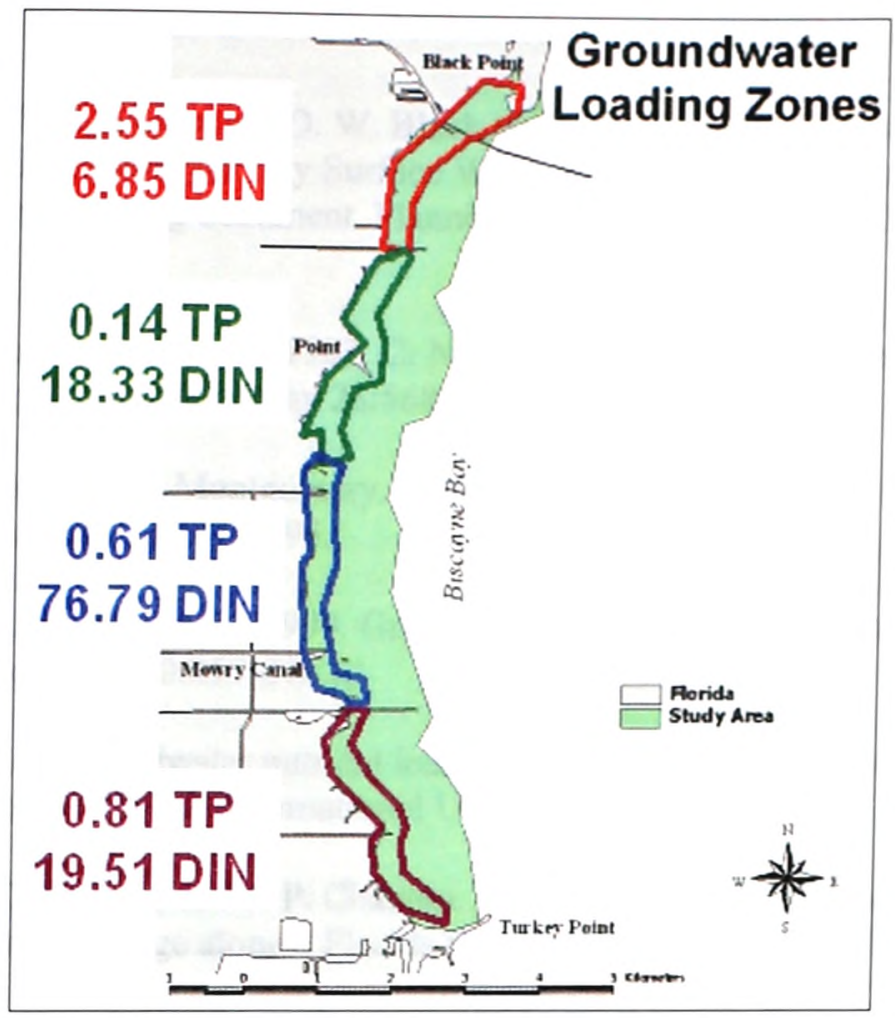

Figure 3.18. Groundwater loads (tons $\mathrm{yr}^{-1}$ ) with for each region.

$\mathrm{Bla}=$ red, Fen $=$ green, Mow $=$ blue and Tur $=$ purple.

Table 3.6. Groundwater nutrient load for the entire study area in tons $\mathrm{yr}^{-1}$ within the first $350 \mathrm{~m}$ offshore.

\begin{tabular}{|c|c|}
\cline { 2 - 2 } \multicolumn{1}{c|}{} & $\begin{array}{c}\text { Nutrient Load (tons } \mathbf{y r}^{-1} \text { ) } \\
\text { Entire Study area }\end{array}$ \\
\hline Nitrate & 18.5 \\
Nitrite & 0.4 \\
Ammonium & 98.1 \\
TN & 414.2 \\
TIN & 115 \\
SRP & 0.80 \\
TP & 3.40 \\
\hline
\end{tabular}




\section{$\underline{\text { Work Cited }}$}

Alleman, R. W., S. A. Bellmund, D. W. Black, S. E. Formati, C. A. Gove, and L. K. Gulick. 1995. Biscayne Bay Surface Water Improvement and Management: technical supporting document. Planning Department of SFWMD, West Palm Beach.

Atkinson, M. J., and S. V. Smith. 1983. C: N: P ratios of benthic marine plants. Limnology \& Oceanography 28:568-574.

Belanger, T. V., and M. T. Montgomery. 1992. Seepage meter errors. Limnology and Oceanography 37:1787-1795.

Bokuniewicz, H., and B. Pavlik. 1990. Groundwater seepage along a Barrier Island. Biogeochemistry 10:257-276.

Byrne, M. J. 1999. Groundwater nutrient loading in Biscayne Bay, Biscayne National Park. Master's. Florida International University, Miami.

Cable, J. E., W. C. Burnett, and J. P. Chanton. 1997a. Magnitude and variations of groundwater seepage along a Florida marine shoreline. Biogeochemistry 38:189205.

Cable, J. E., W. C. Burnett, J. P. Chanton, D. R. Corbett, and P. H. Cable. 1997b. Field evaluation of seepage meters in the coastal marine environment. Estuarine, Coastal and Shelf Science 45:367-375.

Caccia, V. G., and J. N. Boyer. In press. A nutrient loading budget for Biscayne Bay, Florida. Marine Pollution Bulletin.

Dennison, W. C., and R. S. Alberte. 1985. Role of daily light period in the depth distribution of Zostera marina (eelgrass). Marine Ecology Progress Series 25:5161 .

Duarte, C. M. 1995. Submerged aquatic vegetation in relation to different nutrient regimes. Ophelia 41:87-112.

Fourqurean, J. W., J. N. Boyer, M. J. Durako, L. N. Hefty, and B. J. Peterson. 2003. Forecasting the response of seagrass distribution to changing water quality: Statistical models from monitoring data. Ecological Applications 13:474-489.

Fourqurean, J. W., M. Durako, M. O. Hall, and L. N. Hefty. 2002. Seagrass distribution in south Florida: A multi-agency coordinated monitoring program. Pages 497-522 in P. J.W. and K. G. Porter, editors. The Everglades, Florida Bay, and Coral Reefs, of the Florida Keys An Ecosystem Sourcebook. CRC Press, Boca Raton. 
Fourqurean, J. W., and L. M. Rutten. 2003. Competing goals of spatial and temporal resolution: monitoring seagrass communities on the regional scale. Pages 257288 in D. E. Busch and J. C. Trexler, editors. Monitoring Ecosystems: Interdisciplinary Applications for Evaluation Ecoregional Initiatives. Island Press, Washington.

Fourqurean, J. W., A. Willsie, C. D. Rose, and L. M. Rutten. 2001. Spatial and temporal pattern in seagrass community composition and productivity in south Florida. Marine Biology 138:341-354.

Fourqurean, J. W., and J. C. Zieman. 2002. Nutrient content of the seagrass Thalassia testudinum reveals regional patterns of relative availability of nitrogen and phosphorus in the Florida Keys USA. Biogeochemistry 61:229-245.

Fourqurean, J. W., G. V. N. Powell, W. J. Kenworthy and J. C. Zieman. 1995. The effects of long-term manipulation of nutrient supply on competition between the seagrasses Thalassia testudinum and Halodule wrightii in Florida Bay. Oikos 72:349-358.

Fourqurean, J. W., J. C. Zieman, and G. V. N. Powell. 1992a. Phosphorous limitation of primary production in Florida Bay: Evidence from $\mathrm{C}: \mathrm{N}: \mathrm{P}$ ratios of the dominant seagrass Thalassia testudinum. Limnology and Oceanography 37:162-171.

Fourqurean, J. W., J. C. Zieman, and G. V. N. Powell. 1992b. Relationships between porewater nutrients and seagrasses in a subtropical carbonate environment. Marine Biology 114:57-65.

Frankovich, T. A., and R. D. Jones. 1998. A rapid, precise and sensitive method for the determination of total nitrogen in natural waters. Marine Chemistry 60:227-234.

Giblin, A. E., and A. G. Gaines. 1990. Nitrogen inputs to a marine embayment: the importance of groundwater. Biogeochemistry 10:309-328.

Howarth, R. W. 1988. Nutrient limitation of net primary production in marine ecosystems. Annual Review of Ecology 19:89-110.

Johannes, R. E. 1980. The ecological significance of the submarine discharge of groundwater. Marine Ecology Progress Series 3:365-373.

Kahn, A. E., and M. J. Durako. 2006. Thalassia testudinum seedling responses to changes in salinity and nitrogen levels. Journal of Experimental Marine Biology and Ecology 335:1-12. 
Kohout, F. A., and M. C. Kolipinski. 1967. Biological zonation related to groundwater discharge along the shore of Biscayne Bay, Miami, Florida. Pages 488-499 in Estuaries:. American Association for the Advancement of Science.

Kufel, L., and I. Kufel. 2002. Chara beds acting as nutrient sinks in shallow lakes- a review. Aquatic botany 72:249-260.

Lapointe, B. E., J. D. O'Connell, and G. S. Garrett. 1990. Nutrient couplings between onsite disposal systems, groundwater, and nearshore surface waters of the Florida Keys. Biogeochemistry 10:289-307.

Lee, D. R. 1977. A device for measuring seepage flux in lakes and estuaries. Limnology and Oceanography 22:140-147.

Lirman, D., and J. W. P. Cropper. 2003. The influence of salinity on seagrass growth, survivorship, and distribution with Biscayne Bay, Florida: field, experimental, and modeling studies. Estuaries 26:131-141.

McClelland, J. W., and I. Valiela. 1998. Linking nitrogen in estuarine producers to landderived sources. Limnology and Oceanography 43:577-585.

Meeder, J., and J. N. Boyer. 2001. Total ammonia concentrations in soil, sediments, surface water, and groundwater along the western shoreline of Biscayne Bay with the focus on Black Point and a reference mangrove site. BISC-N-011.000, Final Report to National Park Service, SERC, FIU, Miami.

Meeder, J. F., J. Alvord, M. Byrns, M. S. Ross, and A. Renshaw. 1997. Distribution of benthic nearshore communities and their relationship to groundwater nutrient loading. BNP, Final Report to Biscayne National Park, SERC, FIU, Miami.

Montague, C. L., and J. A. Ley. 1993. A possible effect of salinity fluctuation on abundance of benthic vegetation and associated fauna in northeastern Florida Bay. Estuaries 16:703-717.

Montague, C. L. 1989. The distribution and dynamics of submerged vegetation along gradients of salinity in northeast Florida Bay. Bulletin of Marine Science 44:521-

Powell, G. V. N., J. W. Fourqurean, W. J. Kenworthy, and J. C. Zieman. 1991. Bird colonies cause seagrass enrichment in a subtropical estuary: observational and experimental evidence. Estuarine, Coastal and Shelf Science 32:567-579.

Robblee, M. B., T. R. Barber, P. R. Carlson, M. J. Durako, J. W. Fourqurean, L. K. Muehlstein, D. Porter, L. A. Yarbro, R. T. Zieman, and J. C. Zieman. 1991. Mass mortality of the tropical seagrass Thalassia testudinum in Florida Bay (USA). Marine Ecology Progress Series 71:297-299. 
Roessler, M., G. L. Beardsley, and R. Smith. 1973. Benthic Communities of Biscayne Bay, Florida. Pages 10 in. University of Miami Sea Grant Program.

Rutkowski, C. M., W. C. Burnett, R. L. Iverson, and J. P. Chanton. 1999. The effect of groundwater seepage on nutrient delivery and seagrass distribution in the northeaster Gulf of Mexico. Estuaries 22:1033-1040.

Short, F. T. 1987. Effects of sediment nutrients on seagrasses: literature review and mesocosm experiment. Aquatic botany 27:41-57.

Short, F. T., M. W. Davis, R. A. Gibson, and C. F. Zimmermann. 1985. Evidence for phosphorus limitation in carbonate sediments of the seagrass Syringodium filiforme. Estuarine, Coastal and Shelf Science 20:419-430.

Short, F. T., W. C. Dennison, and D. G. Capone. 1990. Phosphorus-limited growth of the tropical seagrass Syringodium filiforme in carbonate sediments. Marine Ecology Progress Series 62:169-174.

Short, F. T., and S. Wyllie-Echeverria. 1996a. Natural and human-induced disturbance of seagrass. Environmental Conservation 23:17-27.

Smith, S. V. 1984. Phosphorous versus nitrogen limitation in the marine environment. Limnology and Oceanography 29:1149-1160.

Smith, S. V., and M. J. Atkinson. 1984. Phosphorus limitation of net production in a confined aquatic system. Nature 307:626-627.

Solórzano, L., and J. H. Sharp. 1980. Determination of total dissolved phosphorus and particulate phosphorus in natural waters. Limnology and Oceanography 25:754758.

Szmant, A. M. 1987. Biological investigations of the Black Creek vicinity, Biscayne National Park. SER-87, Biscayne National Park, National Park Service, U.S. Department of the Interior, Homestead.

Thorhaug, A. 1976. The vascular plants of Biscayne Bay. Pages 315+ in A. Thorhaug and A. Volker, editors. Biscayne Bay Symposium I. Sea Grant Program, University of Miami.

Tilman, D. 1982. Resource competition and community structure. Princeton Univ. Press. Princeton, NJ. 
Valiela, I., J. Costa, K. Foreman, J. M. Teal, B. Howes, and D. Aubrey. 1990. Transport of groundwater-bourne nutrients from watersheds and their effects on coastal waters. Biogeochemistry 10:177-197.

Valiela, I., J. W. McClelland, J. Hauxwell, P. J. Behr, D. Hersh, and K. Foreman. 1997. Macroalgal blooms in shallow estuaries: Controls and ecophysiological and ecosystem consequences. Limnology and Oceanography 42:1105-1118.

Zieman, J. C. 1975. Seasonal variation of turtle grass, Thalassia testudinum König, with reference to temperature and salinity effects. Aquatic botany 1:107-123. 


\section{SUMMARY}

The relationships between benthic macrophyte communities and the effects of surface water and groundwater nutrient concentrations are of interest largely because of increased degradation of estuarine areas. Frequencies of natural and human-influenced disturbances of seagrasses around the world have been examined to find that most are affected by human related pollution within coastal waters (Short and Wyllie-Echeverria 1996a). Effects of groundwater on benthic vegetation are not well understood or documented since this diffusive input is difficult to quantify. The presence of two landfills and a large agricultural area in South Miami-Dade pose a definite threat to groundwater quality. Therefore, the finding in this study will aid coastal researchers, managers and regulation agencies in Biscayne Bay along with the current water management activities related to Everglades Restoration.

Chapter 2, documented the distribution of macrophytes in southwestern Biscayne Bay obtained by a 207 site survey. Marine species dominated at Turkey Point and offshore where salinities and water depth were greatest. The entire northern area, Black Point, was dominated by brackish water tolerant species within the first $300 \mathrm{~m}$ offshore. Thalassia testudinum was found offshore and south, Halodule wrightii dominated along shore and Ruppia maritima was predominant nearshore at the Black Pont. The spatial differences of benthic macrophytes northward from Turkey Point to Black Point, may be caused by the increase of poor quality canal discharge (CD) and/ or submarine groundwater discharge (SGD). Groundwater discharge into estuarine areas has received increased attention over the last few years, and now it is recognized as a potential pathway for nutrient transport. 
Chapter 3, explored potential causes for spatial variation found in the nearshore seagrass communities. Marine species correlated with high salinity and lowered nutrients while the opposite was found for brackish water tolerant species. A significant decline in Thalassia testudinum and concomitant increase in Halodule wrightii was significantly correlated with decreased salinity and increased ammonium and total phosphorus concentrations from the water column and groundwater seepage. Seagrass tissue $\mathrm{C}$ : $\mathrm{P}$ values correlated with salinity indicating higher phosphorus availability in the brackish water around Black Point.

Overall, nutrient enriched freshwater appears to influence the seagrass community structure at Black Point and along the shore towards Turkey Point. Black Point should be an area of concern, due to increased total phosphorus and ammonium concentrations found in both water column and groundwater seepage along with the absence of Thalassia. Seasonality did not determine the amount of groundwater flow into the area, but it is the managing practices used in south Florida from the hydraulic head maintained by the L31E levee. Individual site groundwater nutrient loads were not significantly correlated with benthic species, therefore rejecting the null hypothesis. Black Point being an area that is very shallow, has the potential to be more influenced by any amount of groundwater nutrient loading. An estimate of groundwater TP load for the entire Black Point region ( $<350 \mathrm{~m}$ offshore) was extrapolated estimating that there is 2.55 metric tons $\mathrm{y}^{-1}$ groundwater TP. This amount of phosphorus is half the canal nutrient load for the entire southern Biscayne Bay. The total phosphorus load for the entire Black Point area is the highest estimate compared to all other load values (Figure 3.17). These findings indicate that nutrients in groundwater are important in determining seagrass community 
structure and spatial distribution in the shallow waters of Biscayne Bay, and that groundwater loads should be included in the development of nutrient budgets. 


\section{APPENDICES}

Appendix 1. Summary statistics for surface and groundwater nutrient concentrations, groundwater nutrient loads and elemental ratios of seagrass tissue for each station $(\mathrm{n}=20)$ over time (6 events). Load $\left(\mu \mathrm{mol} \mathrm{m}^{-2} \mathrm{~d}^{-1}\right)$

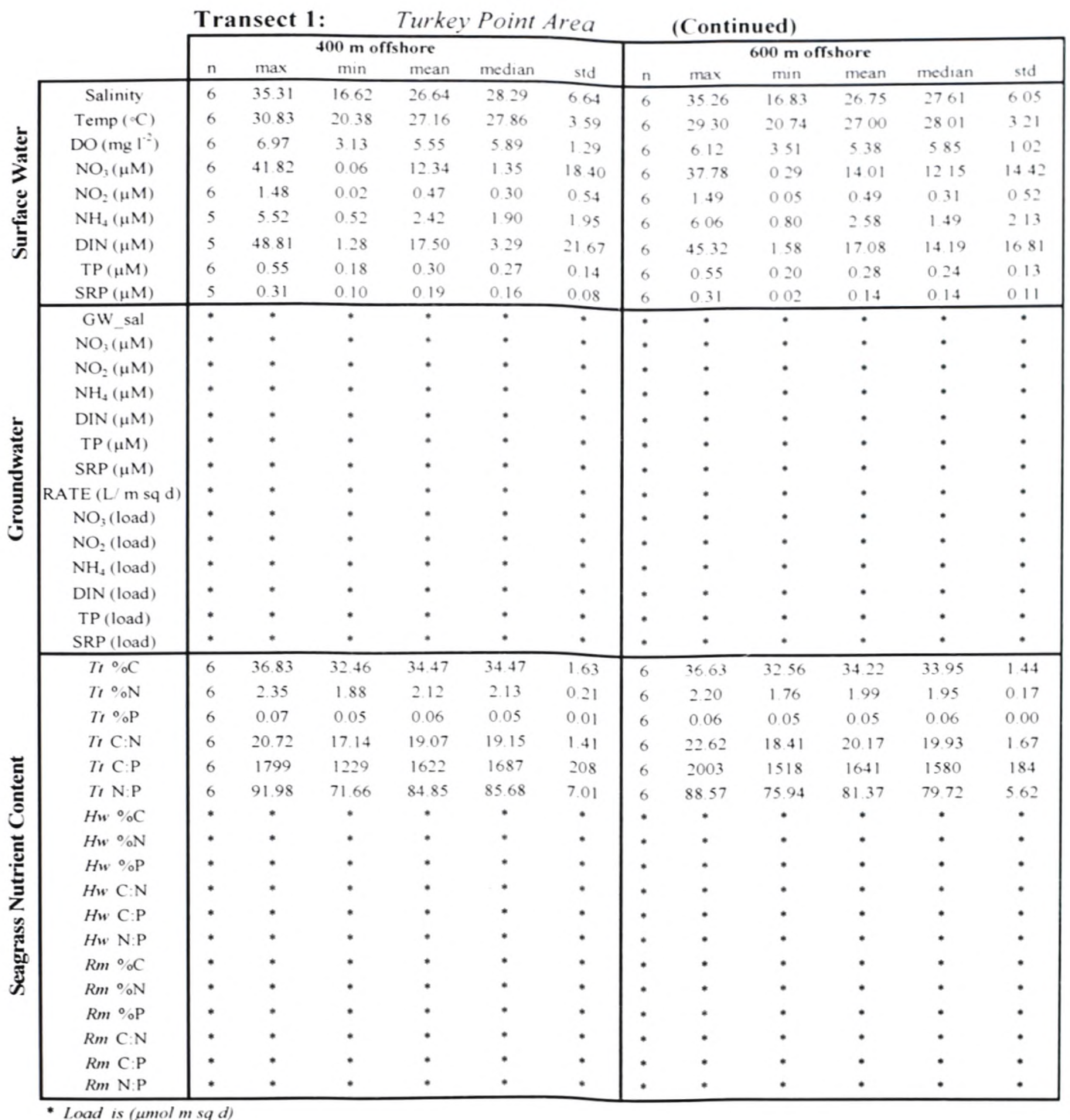


Transect 1:

Turkey Point Area

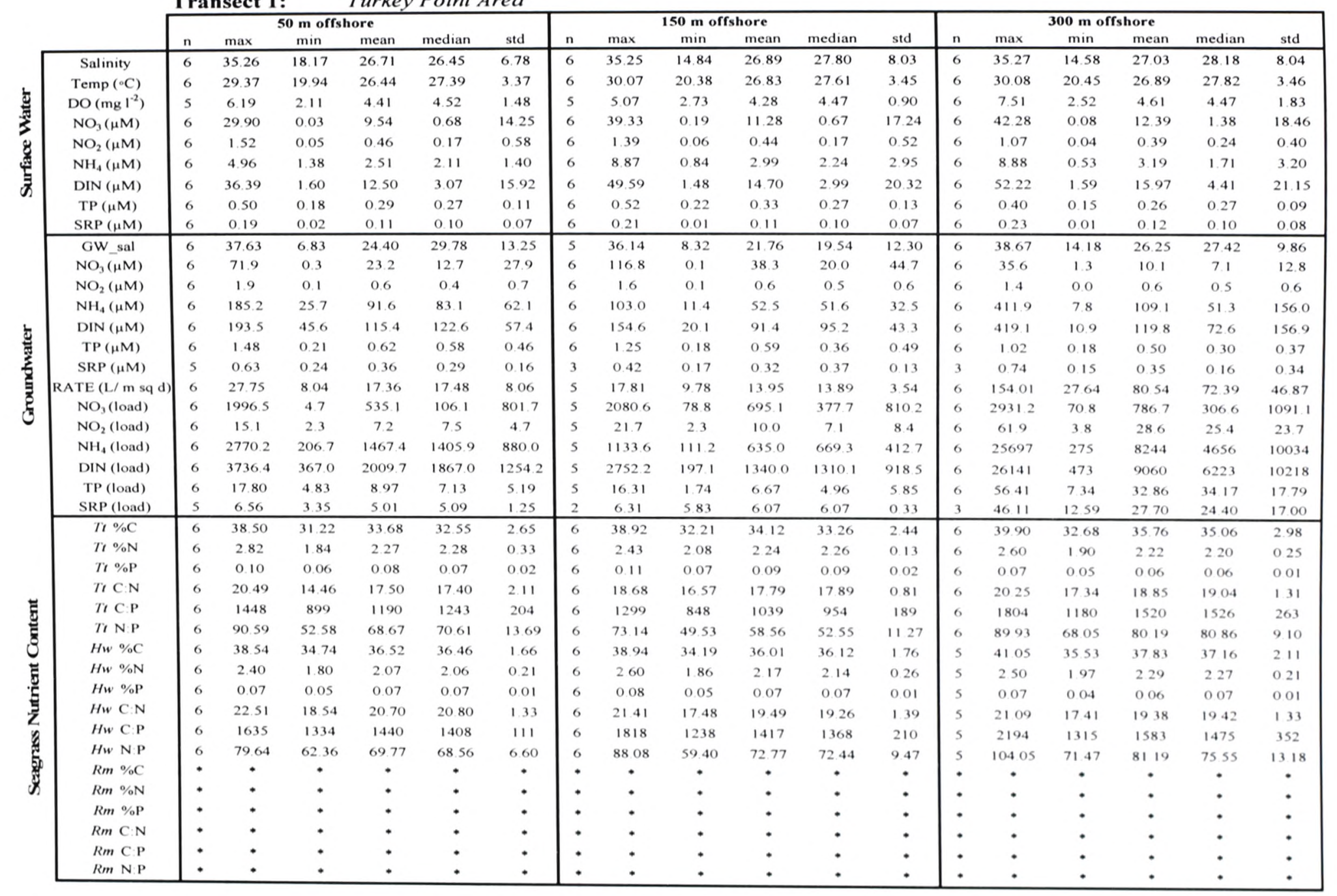


Transect 2:

Mowry Canal Area

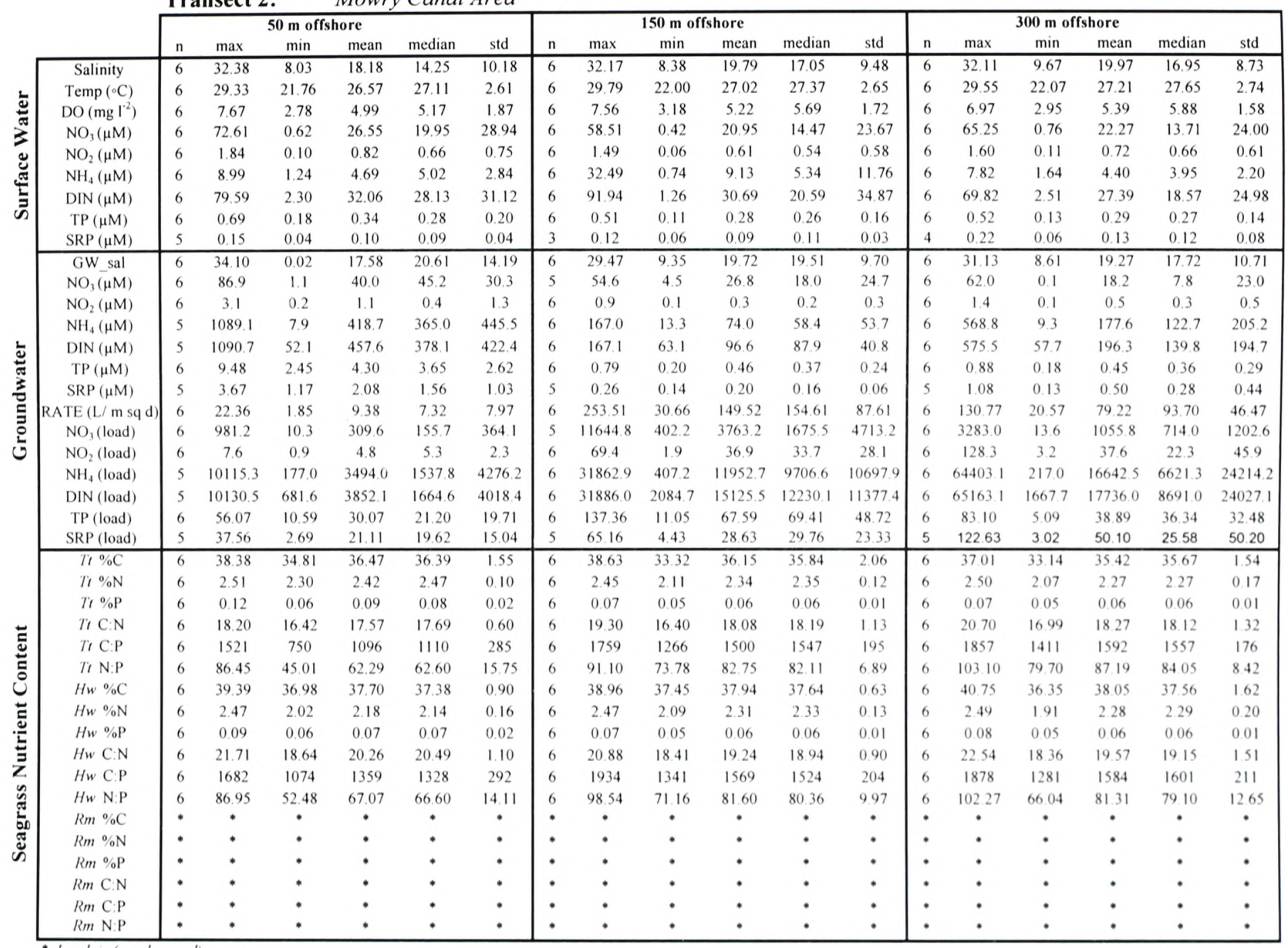


Transect 2: $\quad$ Mowry Canal Area (Continued)

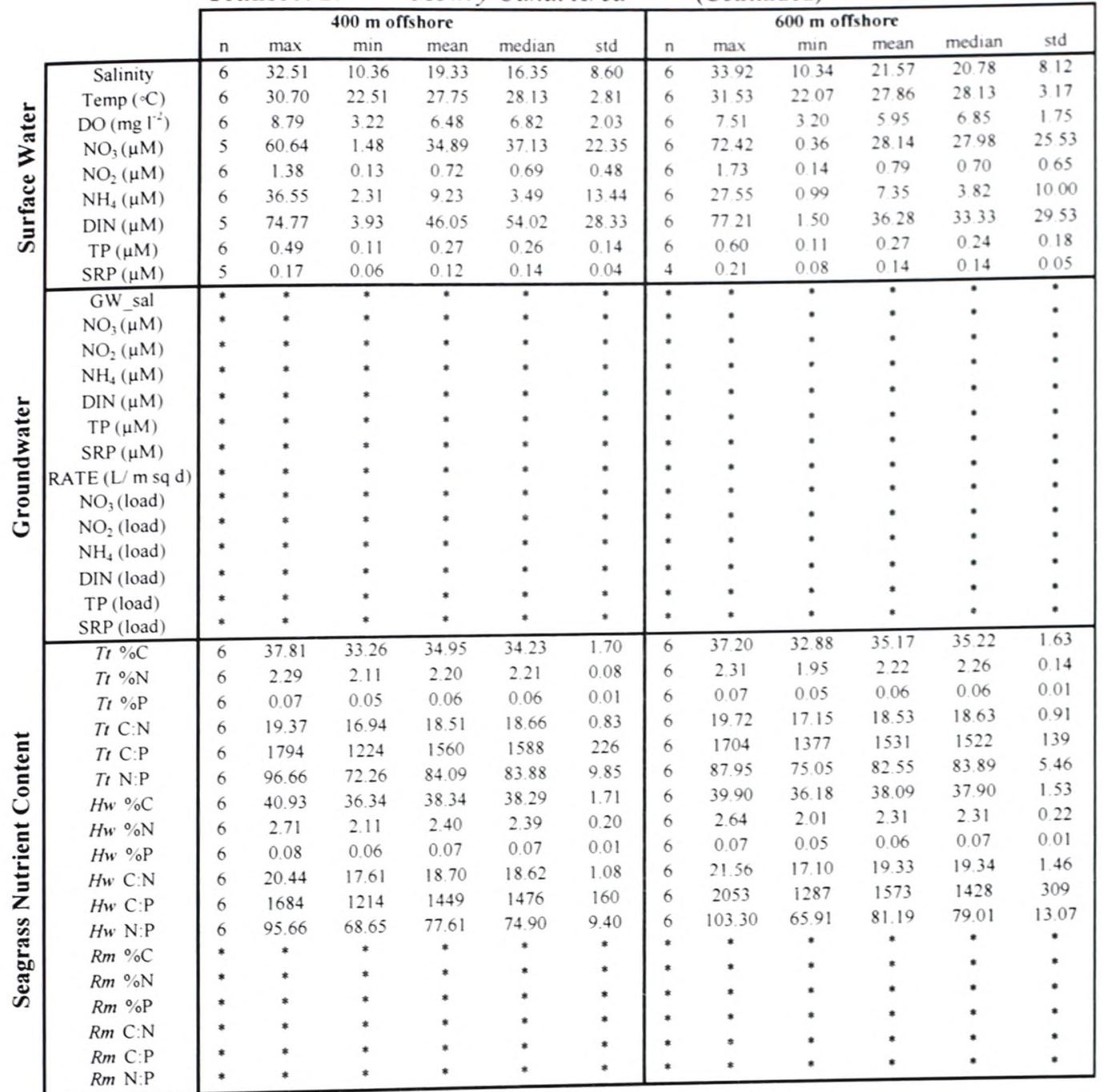

* Load is ( $\mu \mathrm{mol} m$ sqd) 
Transect 3: $\quad$ Fender Point Area

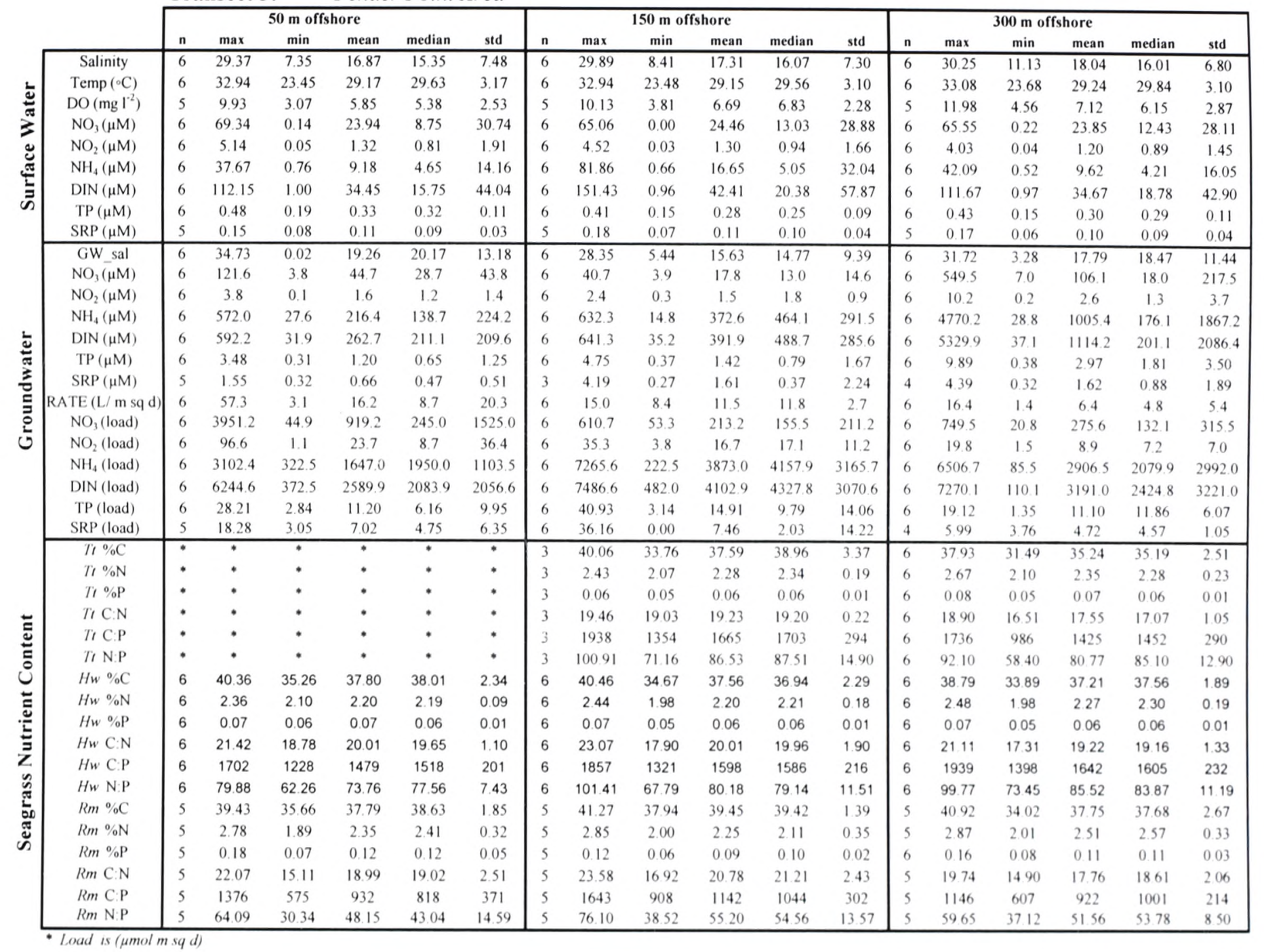


Transect 3: Fender Point Area (Continued)

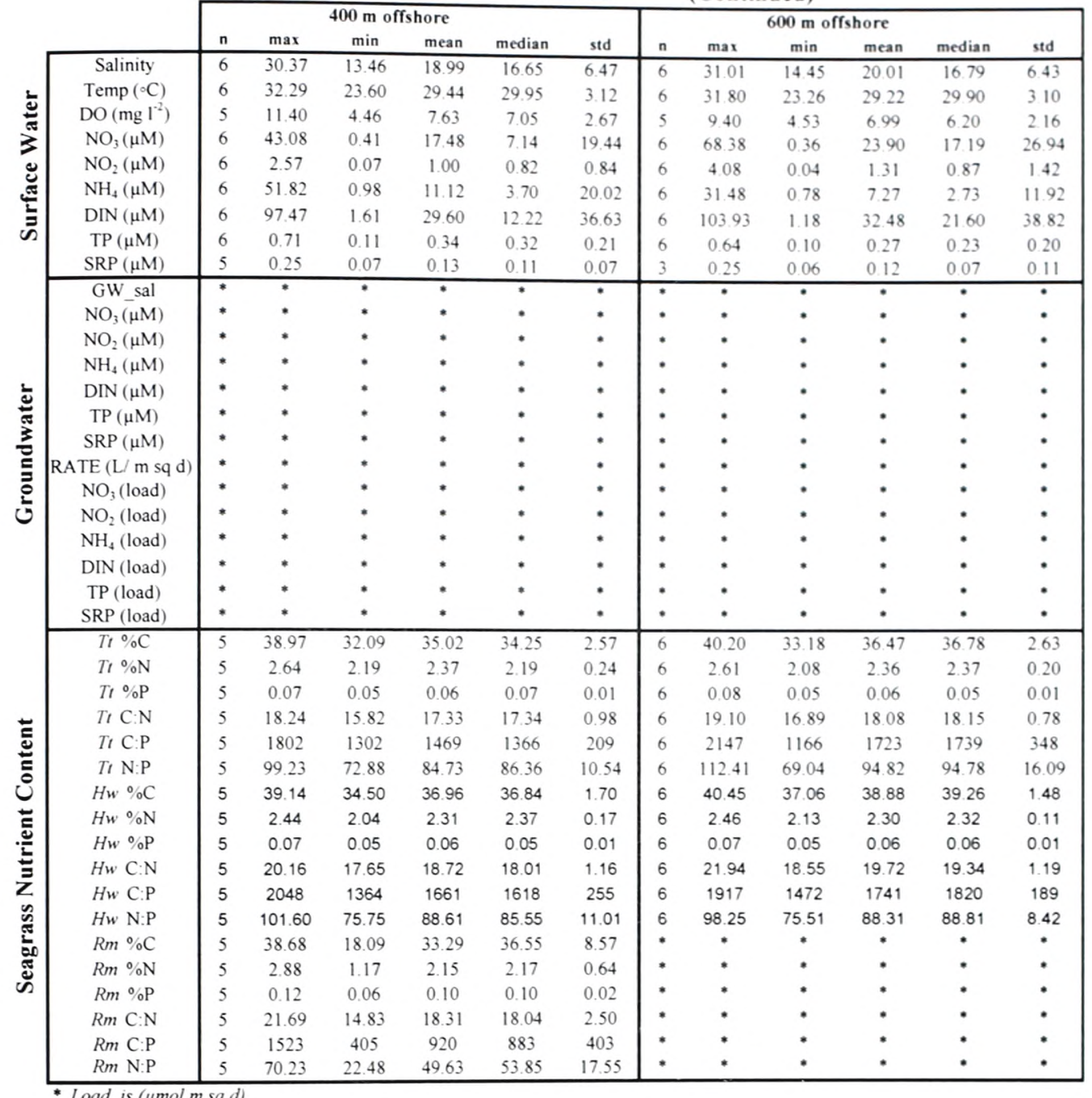


Transect 4: $\quad$ Black Point Area

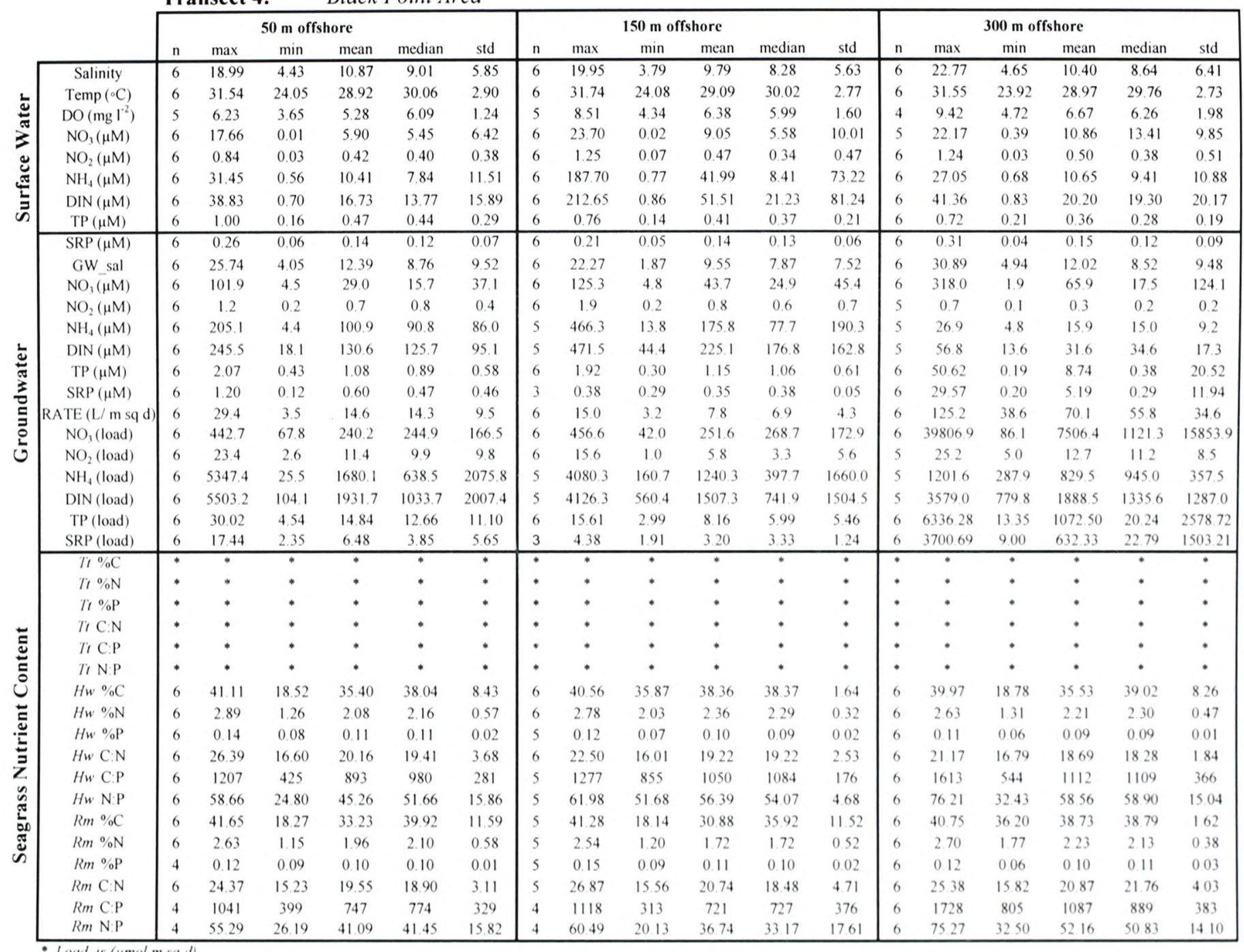


Transect 4: Black Point Area (Continued)

\begin{tabular}{|c|c|c|c|c|c|c|c|c|c|c|c|c|c|}
\hline & \multirow{2}{*}{\multicolumn{6}{|c|}{$400 \mathrm{~m}$ offshore }} & & & & & & \\
\hline & & & & & & & & \multicolumn{6}{|c|}{$600 \mathrm{~m}$ offshore } \\
\hline & & $\mathrm{n}$ & $\max$ & $\min$ & mean & median & std & $n$ & $\max$ & $\min$ & mean & median & std \\
\hline \multirow{9}{*}{ 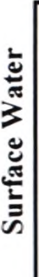 } & Salinity & 5 & 10.83 & 5.13 & 8.22 & 8.47 & 2.10 & 6 & 23.96 & 5.00 & 10.74 & 8.65 & 683 \\
\hline & Temp $\left({ }^{\circ} \mathrm{C}\right)$ & 5 & 31.09 & 23.79 & 28.91 & 29.62 & 2.94 & 6 & 31.33 & 2388 & 2968 & 30.74 & 288 \\
\hline & $\mathrm{DO}\left(\mathrm{mg} \mathrm{l}^{-2}\right)$ & 4 & 9.91 & 4.87 & 6.47 & 5.54 & 2.32 & 4 & 8.95 & 4.17 & 6.27 & 5.97 & 200 \\
\hline & $\mathrm{NO}_{3}(\mu \mathrm{M})$ & 6 & 33.10 & 0.71 & 11.04 & 5.59 & 13.13 & 6 & 94.93 & 0.92 & 33.94 & 27.05 & 3424 \\
\hline & $\mathrm{NO}_{2}(\mu \mathrm{M})$ & 6 & 1.22 & 0.03 & 0.58 & 0.56 & 0.39 & 6 & 3.38 & 0.02 & 1.25 & 1.12 & 1.16 \\
\hline & $\mathrm{NH}_{4}(\mu \mathrm{M})$ & 6 & 15.52 & 0.44 & 667 & 5.77 & 6.44 & 5 & 20.69 & 0.77 & 832 & 4.83 & 829 \\
\hline & $\operatorname{DIN}(\mu \mathrm{M})$ & 6 & 45.21 & 1.18 & 18.30 & 11.64 & 18.99 & 5 & 10864 & 1.71 & 49.21 & 50.62 & 3910 \\
\hline & $\mathrm{TP}(\mu \mathrm{M})$ & 6 & 0.62 & 0.15 & 0.34 & 0.25 & 0.22 & 6 & 0.77 & 0.14 & 0.34 & 0.23 & 0.24 \\
\hline & $\operatorname{SRP}(\mu \mathrm{M})$ & 6 & 0.20 & 0.04 & 0.12 & 0.12 & 0.05 & 6 & 0.19 & 0.06 & 0.13 & 0.13 & 005 \\
\hline \multirow{14}{*}{ 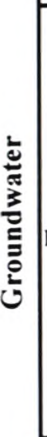 } & GW_sal & $*$ & $*$ & $*$ & 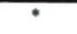 & $\bar{*}$ & $\bar{*}$ & $\bar{*}$ & 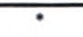 & $\bar{*}$ & $\cdot$ & $\cdot$ & $\cdot$ \\
\hline & $\mathrm{NO}_{3}(\bar{M} \mathrm{M})$ & * & • & * & • & * & * & $\cdot$ & • & • & • & - & • \\
\hline & $\mathrm{NO}_{2}(\mu \mathrm{M})$ & * & * & * & * & • & - & $\cdot$ & - & - & • & • & • \\
\hline & $\mathrm{NH}_{4}(\mu \mathrm{M})$ & * & * & $*$ & • & • & • & $\cdot$ & • & • & • & • & • \\
\hline & $\operatorname{DIN}(\mu \mathrm{M})$ & $*$ & * & * & * & - & • & • & • & - & $\cdot$ & - & - \\
\hline & $\mathrm{TP}(\mu \mathrm{M})$ & * & • & * & • & • & • & $\cdot$ & • & - & • & • & • \\
\hline & $\operatorname{SRP}(\mu \mathrm{M})$ & * & * & $*$ & * & * & * & * & • & • & • & - & • \\
\hline & $\operatorname{RATE}(\mathrm{L} / \mathrm{m} \mathrm{sq}$ d) & * & * & * & * & • & • & * & • & - & • & • & • \\
\hline & $\mathrm{NO}_{3}$ (load) & * & * & * & • & • & - & • & - & - & • & • & • \\
\hline & $\mathrm{NO}_{2}$ (load) & * & * & $*$ & $*$ & - & * & $\cdot$ & $\cdot$ & • & • & • & • \\
\hline & $\mathrm{NH}_{4}$ (load) & * & * & * & • & • & * & * & * & • & • & • & • \\
\hline & DIN (load) & * & • & * & * & • & * & * & • & - & - & • & - \\
\hline & TP (load) & $*$ & * & * & • & • & * & • & • & - & - & - & • \\
\hline & SRP (load) & $*$ & $*$ & $*$ & $\cdot$ & $\cdot$ & $*$ & $\cdot$ & $\cdot$ & - & - & * & • \\
\hline \multirow{18}{*}{ 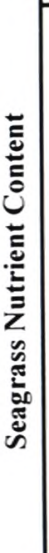 } & $T t \% \mathrm{C}$ & $*$ & $\bar{*}$ & $*$ & * & $\cdot$ & $*$ & $*$ & * & $\cdot$ & $\cdot$ & * & $\cdot$ \\
\hline & Tr $\% \mathrm{~N}$ & * & - & * & • & - & * & • & • & - & - & - & - \\
\hline & $T t \% \mathrm{P}$ & * & * & * & * & - & * & • & * & • & - & - & • \\
\hline & $T t \mathrm{C}: \mathrm{N}$ & * & $*$ & * & * & • & * & * & • & * & - & - & • \\
\hline & Tt C:P & * & • & $*$ & • & • & * & * & • & * & - & - & • \\
\hline & $T t \mathrm{~N}: \mathrm{P}$ & * & $*$ & * & • & - & * & • & * & • & $\cdot$ & $\cdot$ & $\cdot$ \\
\hline & $\mathrm{Hw}_{w} \% \mathrm{C}$ & 6 & 40.35 & 37.08 & 38.68 & 38.50 & 1.31 & 5 & 38.66 & 36.81 & 37.95 & 38.61 & 0.94 \\
\hline & $H_{w} \% \mathrm{~N}$ & 6 & 2.82 & 2.08 & 2.51 & 2.64 & 0.29 & 5 & 2.56 & 2.26 & 2.39 & 2.31 & 0.15 \\
\hline & $H w \% \mathrm{P}$ & 6 & 0.12 & 0.06 & 0.09 & 0.10 & 0.02 & 6 & 0.10 & 0.06 & 0.08 & 0.08 & 0.01 \\
\hline & $H w C: N$ & 6 & 20.80 & 16.43 & 18.15 & 17.31 & 2.05 & 5 & 19.99 & 16.91 & 1860 & 18.59 & 1.31 \\
\hline & $H w C: \mathrm{P}$ & 6 & 1630 & 863 & 1112 & 1054 & 281 & 5 & 1531 & 1027 & 1278 & 1271 & 245 \\
\hline & $H w$ N:P & 6 & 79.25 & 52.32 & 60.95 & 54.88 & 11.28 & 5 & 82.34 & 51.39 & 68.76 & 71.56 & 12.34 \\
\hline & $R m \% \mathrm{C}$ & 5 & 40.43 & 37.15 & 38.75 & 38.39 & 1.31 & 2 & 39.35 & 36.90 & 38.12 & 38.12 & 1.73 \\
\hline & $R m \% \mathrm{~N}$ & 5 & 3.17 & 2.05 & 2.50 & 2.41 & 0.44 & 2 & 2.81 & 2.07 & 2.44 & 2.44 & 0.52 \\
\hline & $R m \% \mathrm{P}$ & 5 & 0.18 & 0.07 & 0.12 & 0.11 & 0.04 & 2 & 0.12 & 0.06 & 0.09 & 0.09 & 0.04 \\
\hline & $R m \mathrm{C}: \mathrm{N}$ & 5 & 23.00 & 14.04 & 18.59 & 19.23 & 3.53 & 2 & 22.19 & 15.35 & 18.77 & 18.77 & 484 \\
\hline & $R m$ C:P & 5 & 1427 & 564 & 956 & 872 & 353 & 2 & 1608 & 824 & 1216 & 1216 & 555 \\
\hline & $R m$ N:P & 5 & 62.04 & 29.31 & 51.03 & 53.83 & 12.83 & 2 & 72.48 & 53.67 & 63.07 & 63.07 & 13.30 \\
\hline
\end{tabular}

Load is ( $\mu \mathrm{mol} m \mathrm{mq}$ d) 
Appendix 2. Individual site groundwater flow rate over time.

$$
\begin{array}{lll}
1=\text { Aug } 02 & 2=\text { Oct. } 02 & 3=\text { Dec. } 02 ; \\
4=\text { Mar 03 } & 5=\text { Apr/May 03 } & 6=\text { Jul 03 }
\end{array}
$$

Flow Rates for Each Transect Area Bimonthly
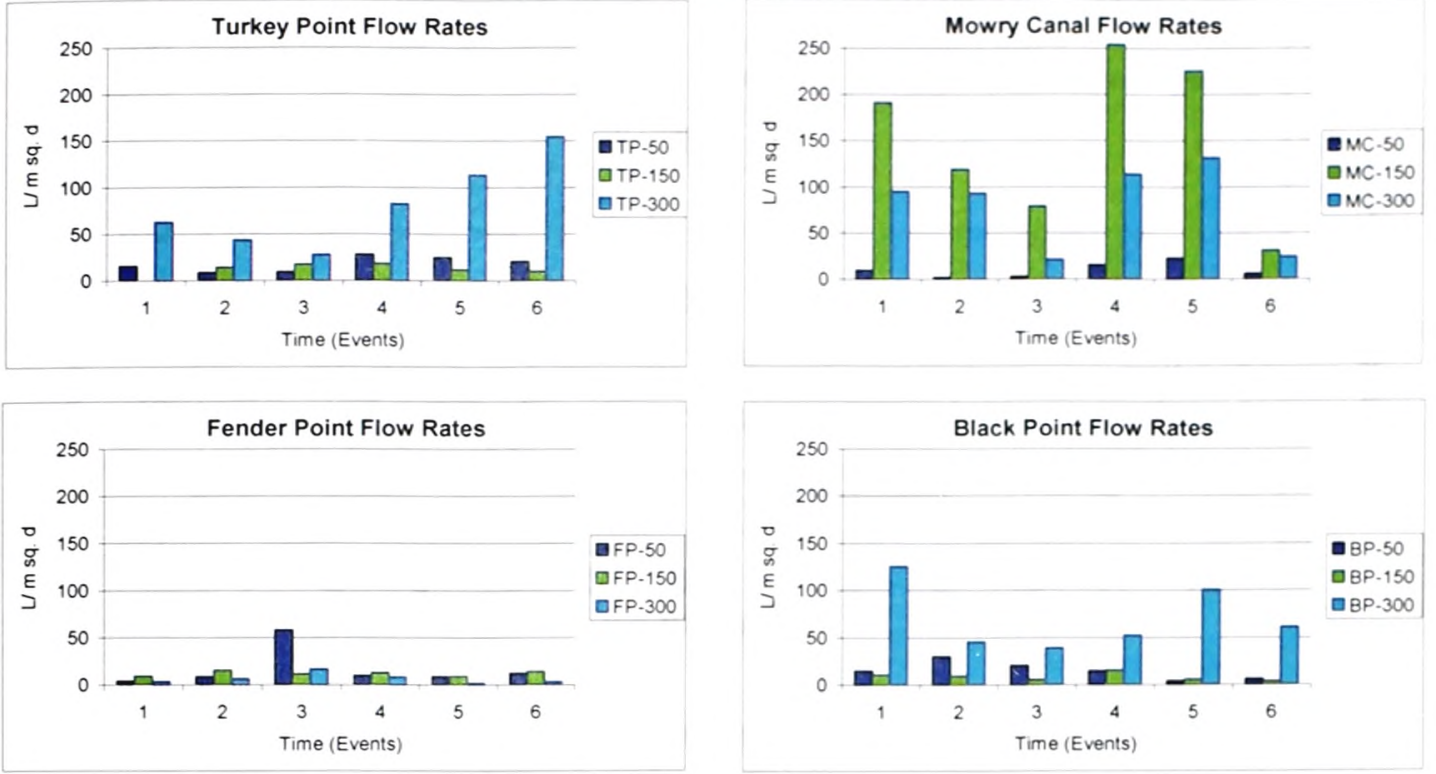

\begin{tabular}{|c|c|c|c|c|}
\hline & \multicolumn{4}{|c|}{ Nutrient Load (tons yr-1) for ea. Study Area } \\
\hline & Tur & Mow & Fen & Bla \\
\hline Nitrate & 3.82 & 10.10 & 2.67 & 2.64 \\
\hline Nitrite & 0.08 & 0.20 & 0.09 & 0.05 \\
\hline Ammonium & 15.61 & 66.49 & 15.56 & 5.82 \\
\hline $\mathrm{TN}$ & 107.79 & 184.02 & 27.13 & 111.09 \\
\hline TIN & 19.51 & 76.79 & 18.33 & 6.85 \\
\hline $\mathrm{TP}$ & 0.18 & 0.61 & 0.14 & 2.55 \\
\hline SRP & 0.19 & 0.48 & 0.09 & 0.11 \\
\hline
\end{tabular}

Appendix 3. Groundwater nutrient loads for each study area (tons $\mathrm{yr}^{-1}$ )

* Groundwater nutrient loads for the entire study area $\left(11.5 \mathrm{~km}^{2}\right)$ 
Appendix 4. Relation between mean groundwater rates vs. sediment type for all groundwater stations.

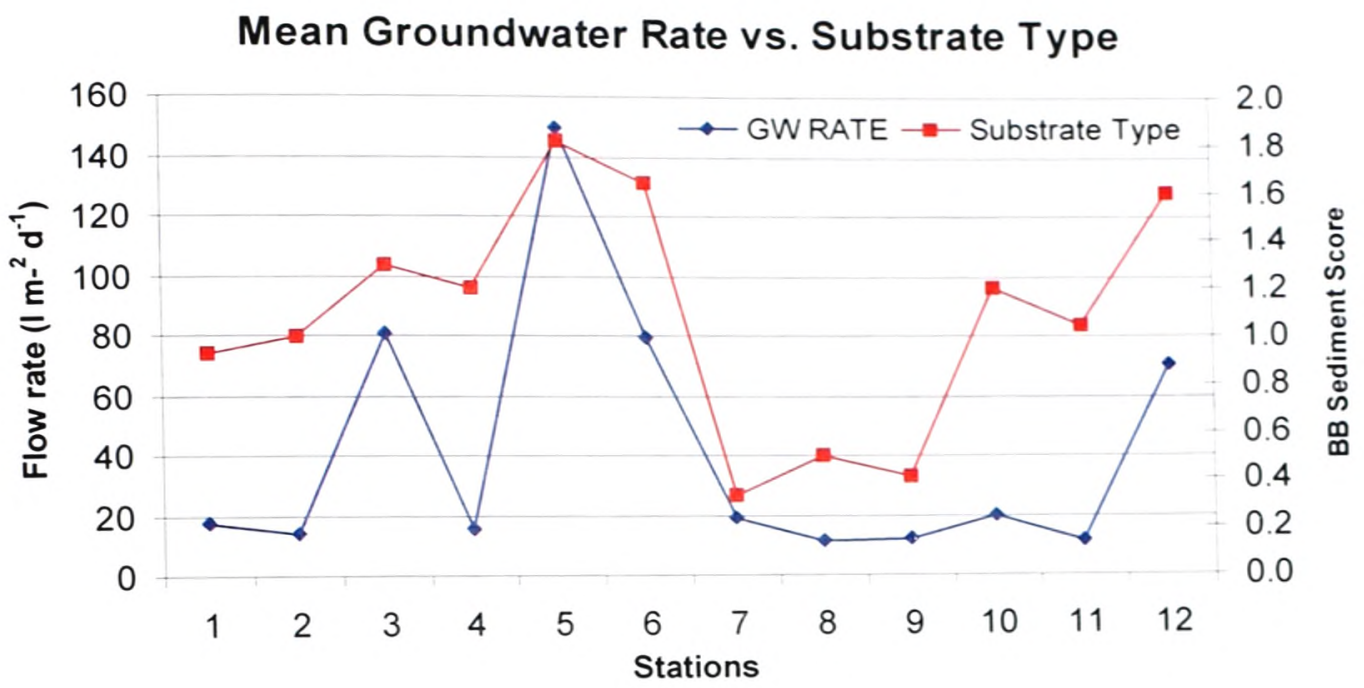

* Sediment type is positively related to groundwater flow rates $(\rho=0.718, p<0.01)$. 
Appendix 5. Raw data charts of groundwater concentrations overtime.

Turkey Point (TP)
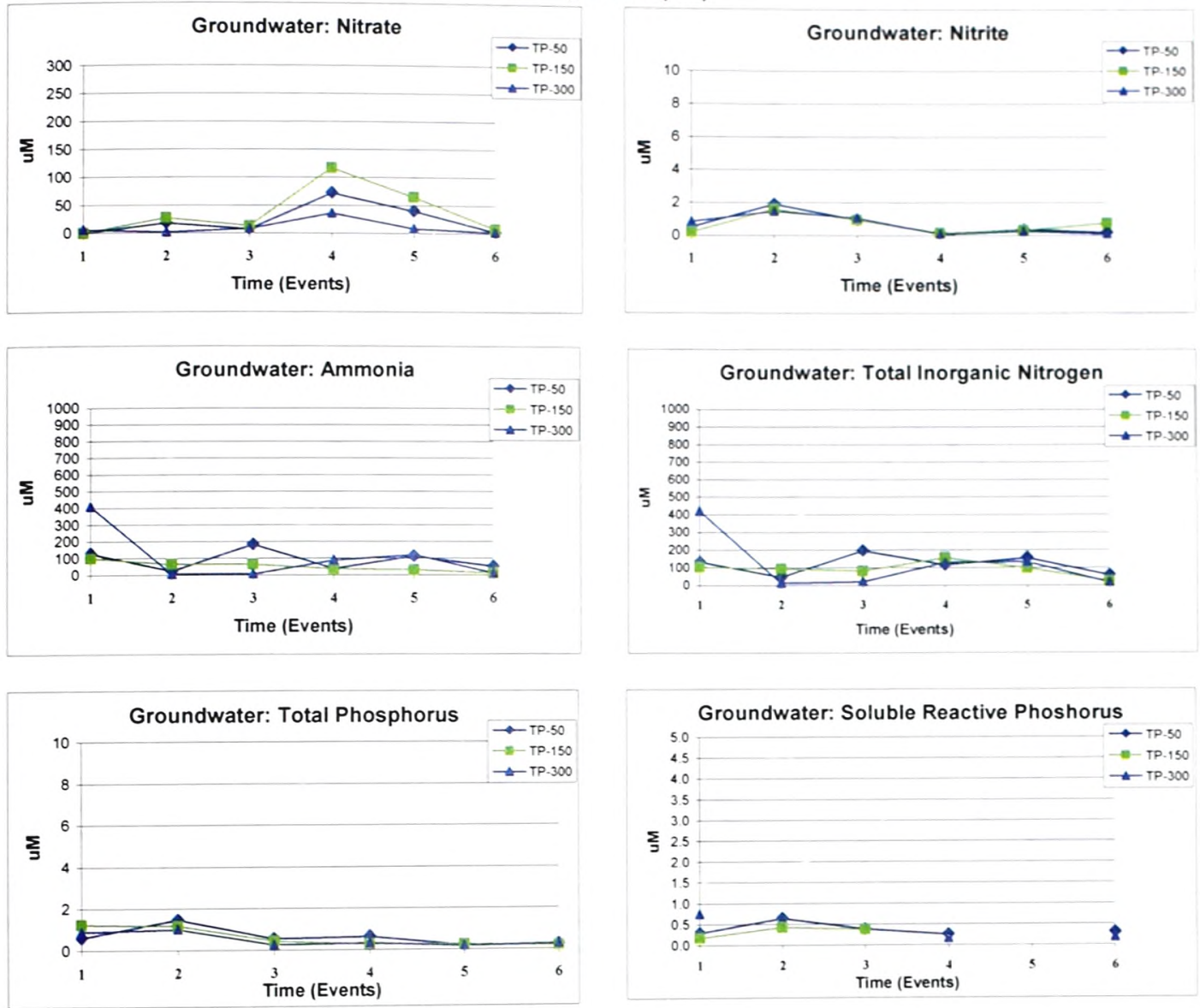


\section{Mowry Canal (MC)}
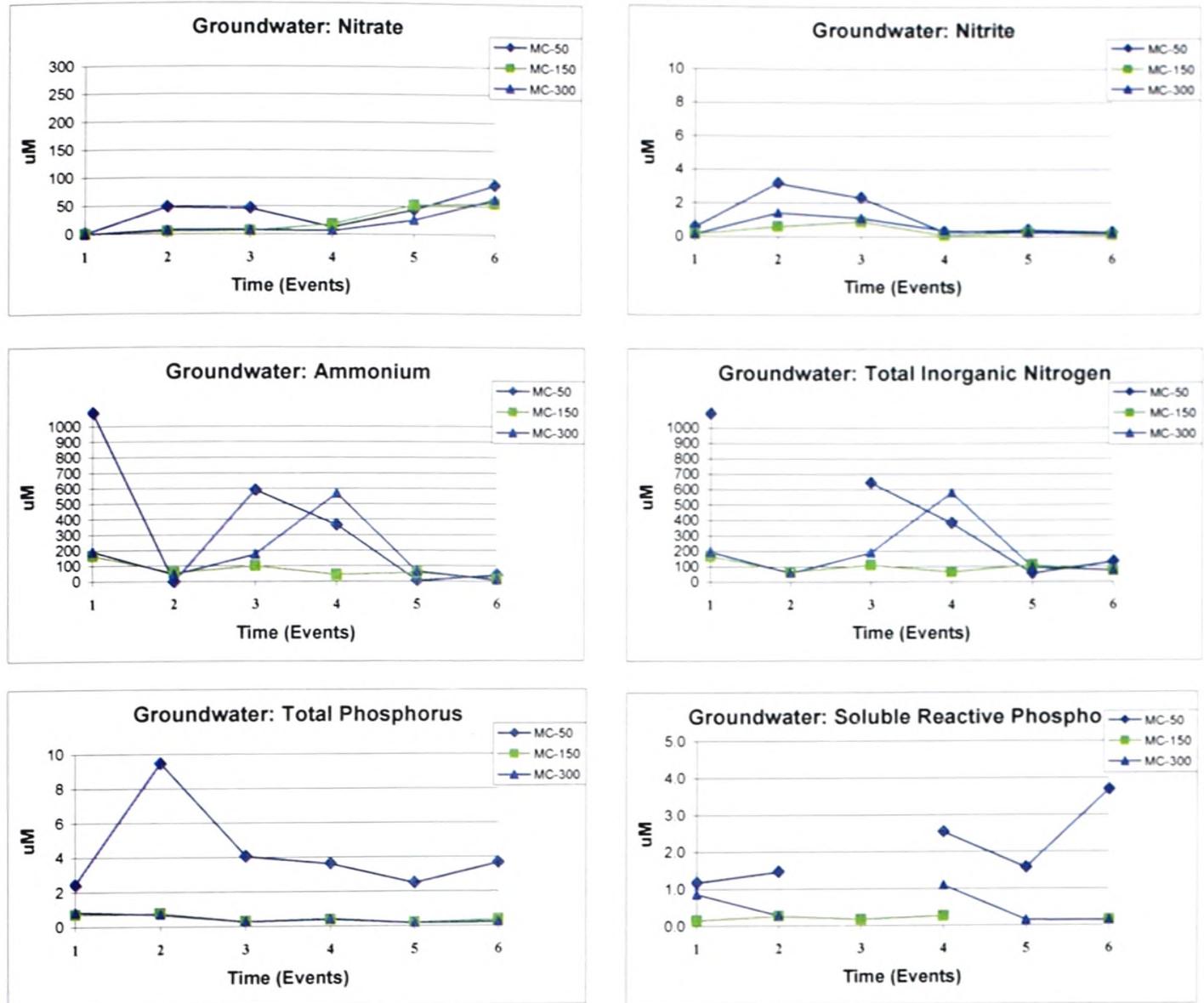


\section{Black Point (BP)}
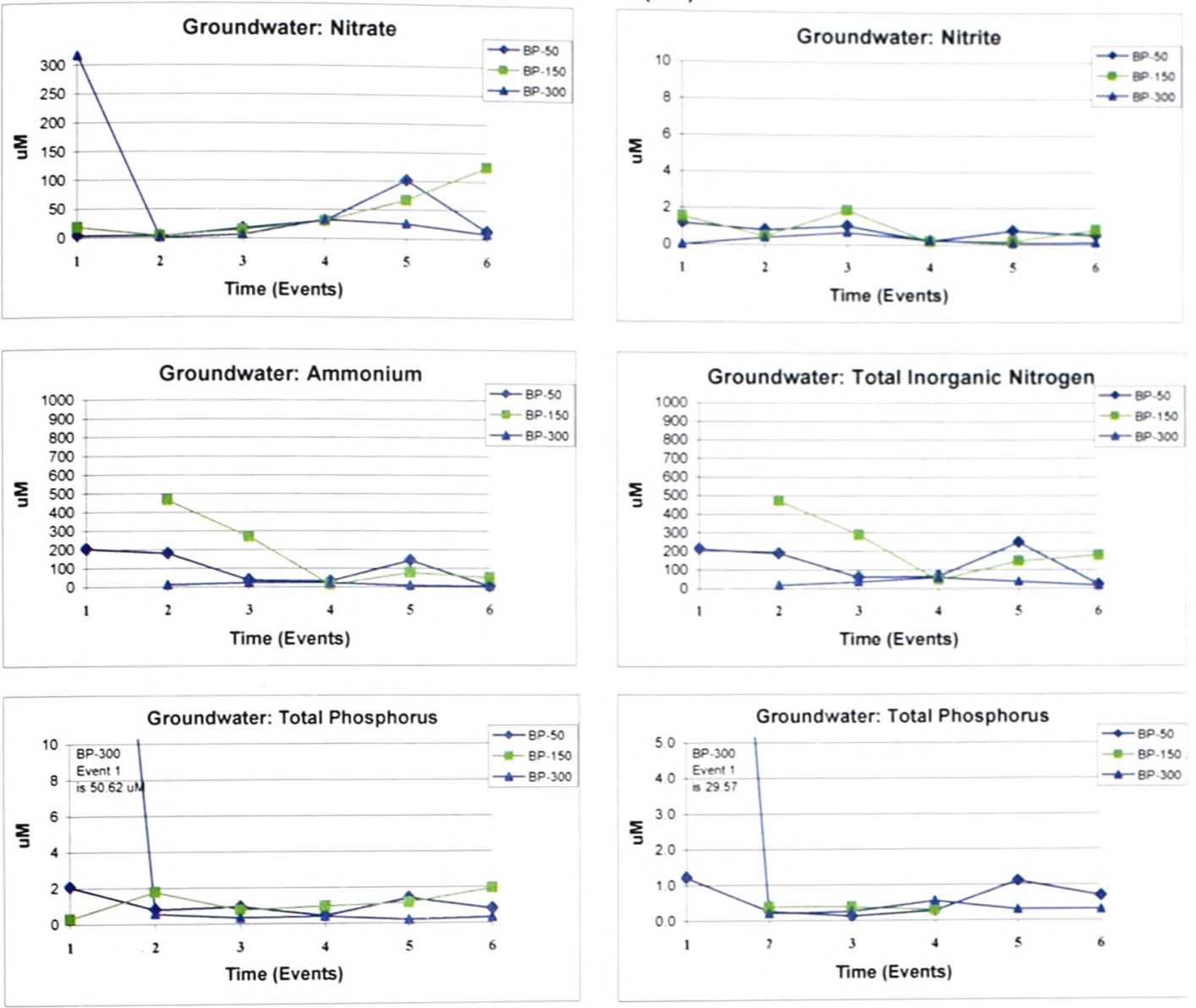


\section{Fender Point (FP)}
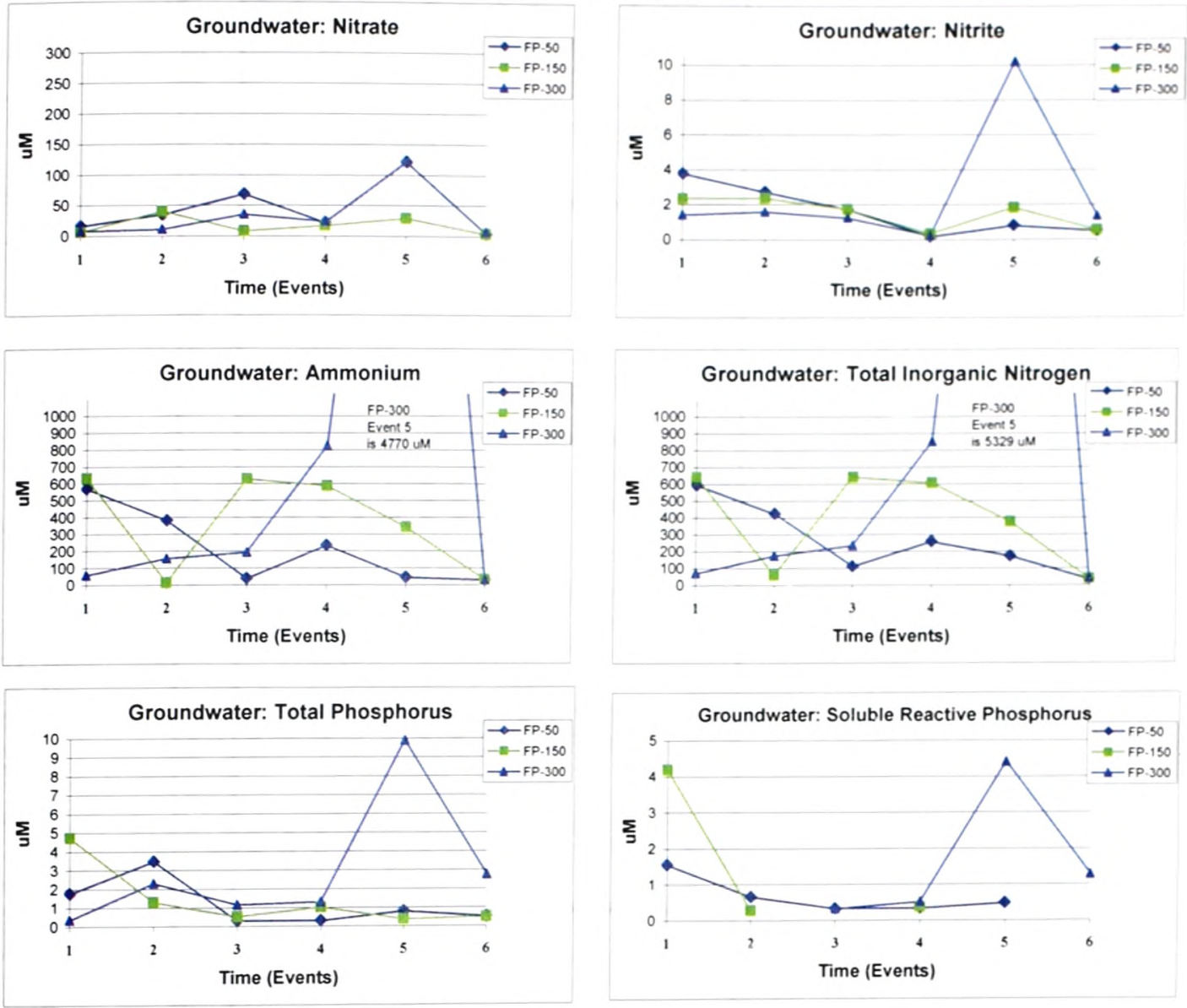
Appendix 6. Nonparametric Mann Whitney Results for taxa density and abundance, surface water and groundwater nutrient concentrations and groundwater nutrient loads between transects that are significant.

\begin{tabular}{|c|c|c|c|c|c|c|c|c|c|c|c|c|}
\hline & \multicolumn{2}{|c|}{ Tur vs Mow } & \multicolumn{2}{|c|}{ Tur vs Fen } & \multicolumn{2}{|c|}{ Tur vs Bla } & \multicolumn{2}{|c|}{ Mow vs Fen } & \multicolumn{2}{|c|}{ Mow vs Bla } & \multicolumn{2}{|c|}{ Fen vs Bla } \\
\hline & $z$ & Sig. & $z$ & Sig. & $z$ & Sig. & Z & Sig. & Z & Sig. & Z & Sig. \\
\hline Thalassia Density & -1.008 & 0.313 & -4.805 & 0.000 & -6.650 & 0.000 & -5.042 & 0.000 & -6.576 & 0.000 & -4.810 & 0.000 \\
\hline Halodule Density & -4.646 & 0.000 & -5.528 & 0.000 & -5.269 & 0.000 & -3.052 & 0.002 & -3.384 & 0.001 & -0.740 & 0.459 \\
\hline Ruppia Density & -1.484 & 0.138 & -4.534 & 0.000 & -5.516 & 0.000 & -3.786 & 0.000 & -4860 & 0.000 & -2.137 & 0.033 \\
\hline Halimeda Density & -3.180 & 0.001 & -4.037 & 0.000 & -3.788 & 0.000 & -1.095 & 0.273 & -1.020 & 0.308 & 0.000 & 1.000 \\
\hline Penicillus Density & -5.507 & 0.000 & -5.446 & 0.000 & -6.651 & 0.000 & -1.813 & 0.070 & -3.746 & 0.000 & -2.159 & 0.031 \\
\hline Acetabularia Density & -1.442 & 0.149 & -4.672 & 0.000 & -1.780 & 0.075 & -3.652 & 0.000 & .0 .645 & 0.519 & -2.516 & 0.012 \\
\hline Batophora Density & -1.218 & 0.223 & -1.104 & 0.270 & -3.071 & 0.002 & -2606 & 0.009 & -4537 & 0.000 & -3.389 & 0.001 \\
\hline Anadyomene & -2.702 & 0.007 & -2.944 & 0.003 & -2.752 & 0.006 & 0.000 & 1.000 & 0.000 & 1.000 & 0.000 & 1.000 \\
\hline Chara Density & 0.000 & 1.000 & -4.711 & 0.000 & -5.516 & 0.000 & -4.561 & 0.000 & -5.350 & 0.000 & -2.457 & 0.014 \\
\hline Cladophora Density & -2.265 & 0.024 & -3.333 & 0.001 & -2.213 & 0.027 & -1.125 & 0.261 & -0.030 & 0.976 & -1.071 & 0.284 \\
\hline Laurencia Density & -1.380 & 0.168 & -4.013 & 0.000 & -4.366 & 0.000 & -3.914 & 0.000 & -4.362 & 0.000 & -1.642 & 0.101 \\
\hline Acanthophora Density & -2.919 & 0.004 & -4.712 & 0.000 & -4.596 & 0.000 & -3.320 & 0.001 & -3.652 & 0.000 & -0.399 & 0.690 \\
\hline Polysiphonia Density & -2.359 & 0.018 & -4.214 & 0.000 & -2.207 & 0.027 & -1.771 & 0.077 & 0000 & 1.000 & -1.950 & 0.051 \\
\hline Chondria Density & -1578 & 0.115 & -0.524 & 0.600 & -3.182 & 0.001 & -1.193 & 0.233 & -2.102 & 0.036 & -3.200 & 0.001 \\
\hline Sargassum Density & -2.701 & 0.007 & -2.002 & 0.045 & -2.752 & 0.006 & -1.303 & 0.193 & 0.000 & 1.000 & -1.328 & 0.184 \\
\hline
\end{tabular}




\begin{tabular}{|c|c|c|c|c|c|c|c|c|c|c|c|c|}
\hline & \multicolumn{2}{|c|}{ Tur vs Mow } & \multicolumn{2}{|c|}{ Tur vs Fen } & \multicolumn{2}{|c|}{ Tur vs Bla } & \multicolumn{2}{|c|}{ Mow vs Fen } & \multicolumn{2}{|c|}{ Mow vs Bla } & \multicolumn{2}{|c|}{ Fen vs Bla } \\
\hline & Z & Sig. & Z & Sig. & Z & Sig. & Z & Sig. & Z & Sig. & Z & Sig. \\
\hline Segrass Abundance & -2.713 & 0.007 & -0.216 & 0.829 & -1.798 & 0.072 & -2.325 & 0.020 & -4.233 & 0.000 & -1.339 & 0.180 \\
\hline Calcareous Green Abundance & -5.055 & 0.000 & -5.837 & 0.000 & -5.245 & 0.000 & -3.314 & 0.001 & -1.536 & 0.124 & -1.909 & 0.056 \\
\hline Green Abundance & -2.665 & 0.008 & -0.576 & 0.565 & -4.520 & 0.000 & -3.086 & 0.002 & -5.635 & 0.000 & -3.838 & 0.000 \\
\hline Red Abundance & -2.703 & 0.007 & -3.558 & 0.000 & -4.312 & 0.000 & -0.195 & 0.846 & -2.005 & 0.046 & -2.229 & 0.026 \\
\hline Brown Abundance & -2.917 & 0.004 & -2.291 & 0.022 & -2.971 & 0.003 & -1.303 & 0.193 & 0.000 & 1.000 & -1.328 & 0.184 \\
\hline Thalassia Abundance & -1.136 & 0.256 & -3.875 & 0.000 & -6.650 & 0.000 & -4.535 & 0.000 & -6.576 & 0.000 & -4.811 & 0.000 \\
\hline Halodule Abundance & -2.729 & 0.006 & -4.853 & 0.000 & -4.637 & 0.000 & -2.612 & 0.009 & -2.884 & 0.004 & -1.208 & 0.227 \\
\hline Ruppia Abundance & -1.484 & 0.138 & -4.711 & 0.000 & -5.516 & 0.000 & -3.935 & 0.000 & -4.767 & 0.000 & -1.321 & 0.187 \\
\hline Halimeda Abundance & -3.157 & 0.002 & -4.038 & 0.000 & -3.789 & 0.000 & -1.095 & 0.273 & -1.020 & 0.308 & 0.000 & 1.000 \\
\hline Penicillus Abundance & -3.889 & 0.000 & -5.737 & 0.000 & -6.650 & 0.000 & -2.318 & 0.020 & -3.747 & 0.000 & -1.913 & 0.056 \\
\hline Acetabularia Abundance & -1.131 & 0.258 & -4.616 & 0.000 & -1.981 & 0.048 & -3.684 & 0.000 & -0.912 & 0.362 & -2.540 & 0.011 \\
\hline Batophora Abundance & -1.777 & 0.076 & -0.104 & 0.917 & -2.527 & 0.011 & -2.342 & 0.019 & -4.562 & 0.000 & -3.387 & 0.001 \\
\hline Anadyomene Abundance & -2.702 & 0.007 & -2.944 & 0.003 & -2.752 & 0.006 & 0.000 & 1.000 & 0.000 & 1.000 & 0.000 & 1.000 \\
\hline Chara Abandance & 0.000 & 1.000 & -4.887 & 0.000 & -5.515 & 0.000 & -4.733 & 0.000 & -5.349 & 0.000 & -2.184 & 0.029 \\
\hline Cladophora Abundance & -2.131 & 0.033 & -3.186 & 0.001 & -2.038 & 0.042 & -1.078 & 0.281 & -0.030 & 0.976 & -1.040 & 0.298 \\
\hline Laurencia Abundance & -0.709 & 0.478 & -4.003 & 0.000 & -4.366 & 0.000 & -3.872 & 0.000 & -4.362 & 0.000 & -1.642 & 0.101 \\
\hline Acanthophora Abundance & -2.710 & 0.007 & -4.539 & 0.000 & -4.596 & 0.000 & -3.150 & 0.002 & -3.652 & 0.000 & -0.796 & 0.426 \\
\hline Polysiphonia Abundance & -1.770 & 0.077 & -3.870 & 0.000 & -1.840 & 0.066 & -1.703 & 0.089 & -0.048 & 0.962 & -1.510 & 0.131 \\
\hline Chondria Abundance & $-1,397$ & 0.162 & -0.543 & 0.587 & -3.182 & 0.001 & -1.204 & 0.229 & -2.102 & 0.036 & -3.200 & 0.001 \\
\hline Sargassum Abundance & -2.701 & 0.007 & -2.002 & 0.045 & -2.752 & 0.006 & -1.303 & 0.193 & 0.000 & 1.000 & -1.328 & 0.184 \\
\hline
\end{tabular}




\begin{tabular}{|c|c|c|c|c|c|c|c|c|c|c|c|c|}
\hline & \multicolumn{2}{|c|}{ Tur vs Mow } & \multicolumn{2}{|c|}{ Tur vs Fen } & \multicolumn{2}{|c|}{ Tur vs Bla } & \multicolumn{2}{|c|}{ Mow vs Fen } & \multicolumn{2}{|c|}{ Mow vs Bla } & \multicolumn{2}{|c|}{ Fen vs Bla } \\
\hline & Z & Sig. & $Z$ & Sig. & $Z$ & Sig. & Z & Sig. & $Z$ & Sig. & Z & Sig. \\
\hline Thalassia C:N & -1.227 & 0.220 & -1.753 & 0.080 & & & -0.812 & 0.417 & & & & \\
\hline Thalassia C:P & -0.665 & 0.506 & -1.604 & 0.109 & & & -0.990 & 0.322 & & & & \\
\hline Thalassia N:P & -1.405 & 0.160 & -2.673 & 0.008 & & & -1.663 & 0.096 & & & & \\
\hline Halodule C:N & -1.406 & 0.160 & -0.919 & 0.358 & -2.178 & 0.029 & -0.485 & 0.628 & -1.790 & 0.073 & -1.943 & 0.052 \\
\hline Halodule C:P & -1.278 & 0.201 & -2.736 & 0.006 & -4.416 & 0.000 & -1.804 & 0.071 & -5.241 & 0.000 & -5.698 & 0.000 \\
\hline Halodule N:P & -1.469 & 0.142 & -3.020 & 0.003 & -3.939 & 0.000 & -1.744 & 0.081 & -4.846 & 0.000 & -5.698 & 0.000 \\
\hline Thalassia \% C & -2.632 & 0.008 & -2.040 & 0.041 & & & -0.248 & 0.804 & & & & \\
\hline Thalassia \% N & -2.514 & 0.012 & -2.417 & 0.016 & & & -0.614 & 0.539 & & & & \\
\hline Halodule \% C & -2.854 & 0.004 & -1.904 & 0.057 & -2.815 & 0.005 & -0.720 & 0.471 & -0.767 & 0.443 & -1.025 & 0.305 \\
\hline Halodule \% N & -2.162 & 0.031 & -1.730 & 0.084 & -2.329 & 0.020 & -0.812 & 0.417 & -0.967 & 0.333 & -1542 & 0.123 \\
\hline Halodule \% P & -0.149 & 0.881 & -1.448 & 0.148 & -4.752 & 0.000 & -1.967 & 0.049 & -5.348 & 0.000 & -5.901 & 0.000 \\
\hline
\end{tabular}

\begin{tabular}{|c|c|c|c|c|c|c|c|c|c|c|c|c|}
\hline & \multicolumn{2}{|c|}{ Tur vs Mow } & \multicolumn{2}{|c|}{ Tur vs Fen } & \multicolumn{2}{|c|}{ Tur vs Bla } & \multicolumn{2}{|c|}{ Mow vs Fen } & \multicolumn{2}{|c|}{ Mow vs Bla } & \multicolumn{2}{|c|}{ Fen vs Bla } \\
\hline & $Z$ & Sig. & Z & Sig. & Z & Sig. & Z & Sig. & $z$ & Sig. & Z & Sig. \\
\hline Surface Salinity & -3.134 & 0.002 & -4.155 & 0.000 & -5.655 & 0.000 & -0.540 & 0.589 & -4.215 & 0.000 & -4.154 & 0.000 \\
\hline Bottom Salinity & -3.112 & 0.002 & -4.849 & 0.000 & -6.338 & 0.000 & -1.774 & 0.076 & -4.382 & 0.000 & -3.912 & 0.000 \\
\hline Surface Temperature & -0.466 & 0.641 & -3.763 & 0.000 & -3.556 & 0.000 & -3.511 & 0.000 & -3.321 & 0.001 & -0.341 & 0.733 \\
\hline Bottom Temperature & -0.569 & 0.569 & -3.038 & 0.002 & -3.290 & 0.001 & -3.312 & 0.001 & -3.275 & 0.001 & -0.569 & 0.570 \\
\hline Surface Dissolved Oxygen & -1.286 & 0.198 & -2.536 & 0.011 & -1.889 & 0.059 & -1.640 & 0.101 & -0.658 & 0.511 & -0.991 & 0.321 \\
\hline Bottom Dissolved Oxygen & -1.833 & 0.067 & -3.279 & 0.001 & -4.047 & 0.000 & -1.251 & 0.211 & -2.565 & 0.010 & -0.842 & 0.400 \\
\hline Nitrate & -2.911 & 0.004 & -1.895 & 0.058 & -0.562 & 0.574 & -0.918 & 0.359 & -2.471 & 0.013 & -1.039 & 0.299 \\
\hline Nitrite & -2.093 & 0.036 & -2.388 & 0.017 & -0.813 & 0.416 & -0.392 & 0.695 & -1.286 & 0.198 & -1.849 & 0.065 \\
\hline Ammonium & -3.146 & 0.002 & -1.539 & 0.124 & -2.216 & 0.027 & -0.732 & 0.464 & -0.500 & 0.617 & -0.697 & 0.485 \\
\hline Total Nitrogen & -1.937 & 0.053 & -1.892 & 0.058 & -0.103 & 0.918 & -0.399 & 0.690 & -1.878 & 0.060 & -1.656 & 0.098 \\
\hline Total Organic Carbon & -1.685 & 0.092 & -4.036 & 0.000 & -5.648 & 0.000 & -3.755 & 0.000 & -4.879 & 0.000 & -3.652 & 0.000 \\
\hline
\end{tabular}




\begin{tabular}{|c|c|c|c|c|c|c|c|c|c|c|c|c|}
\hline & \multicolumn{2}{|c|}{ Tur vs Mow } & \multicolumn{2}{|c|}{ Tur vs Fen } & \multicolumn{2}{|c|}{ Tur vs Bla } & \multicolumn{2}{|c|}{ Mow vs Fen } & \multicolumn{2}{|c|}{ Mow vs Bla } & \multicolumn{2}{|c|}{ Fen vs Bla } \\
\hline & Z & Sig. & Z & Sig. & $\underline{Z}$ & Sig. & Z & Sig. & Z & Sig. & Z & Sig. \\
\hline Groundwater Salinity & -1.518 & 0.129 & -1.881 & 0.060 & -3.416 & 0.001 & -0.301 & 0.764 & -2.246 & 0.025 & -1.804 & 0.071 \\
\hline Groundwater Nitrite & -0.206 & 0.837 & -2.737 & 0.006 & -0.047 & 0.962 & -2.737 & 0.006 & -0.459 & 0.646 & -2.769 & 0.006 \\
\hline Groundwater Ammonium & -0.966 & 0.334 & -2.310 & 0.021 & -0.345 & 0.730 & -1.208 & 0.227 & -1.168 & 0.243 & -2.519 & 0.012 \\
\hline Groundwater Total Nitrogen & -0.854 & 0.393 & -3.132 & 0.002 & -1.803 & 0.071 & -3.290 & 0.001 & -1.962 & 0.050 & -1.202 & 0.229 \\
\hline Groundwater Tot. Inorganic Nitrogen & -1.153 & 0.249 & -2.574 & 0.010 & -0.288 & 0.773 & -1.173 & 0.241 & -1.357 & 0.175 & -2.277 & 0.023 \\
\hline Groundwater Tot. Organic Nitrogen & -0.416 & 0.678 & -1.842 & 0.066 & -1.657 & 0.098 & -1.893 & 0.058 & -1.747 & 0.081 & -0.146 & 0.884 \\
\hline Groundwater Total Phosphorus & -1.472 & 0.141 & -2.753 & 0.006 & -2.057 & 0.040 & -0.997 & 0.319 & -0.301 & 0.764 & -0.918 & 0.359 \\
\hline Groundwater Total Organic Carbon & -1.455 & 0.146 & -3.101 & 0.002 & -1.455 & 0.146 & -2.499 & 0.012 & -1.962 & 0.050 & -1.123 & 0.261 \\
\hline Groundwater Rate $\left(1 \mathrm{~m}^{-2} \mathrm{~d}^{-1}\right)$ & -1.155 & 0.248 & -3.532 & 0.000 & -1.007 & 0.314 & -3.164 & 0.002 & -1.772 & 0.076 & -1.946 & 0.052 \\
\hline Ammonium Load & -1.584 & 0.113 & -0.660 & 0.509 & -1.009 & 0.313 & -1.708 & 0.088 & -2.450 & 0.014 & -1.587 & 0.112 \\
\hline Total Inorganic Nitrogen Load & -2.145 & 0.032 & -0.363 & 0.717 & -0.792 & 0.428 & -2.183 & 0.029 & -3.105 & 0.002 & -1.484 & 0.138 \\
\hline Total Organic Nitrogen Load & -0.349 & 0.727 & -0.438 & 0.662 & -2.171 & 0.030 & -0.194 & 0.846 & -1.945 & 0.052 & -2.323 & 0.020 \\
\hline Total Phosphorus Load & -2.904 & 0.004 & -0.231 & 0.817 & -0.363 & 0.717 & -3.259 & 0.001 & -2.468 & 0.014 & -0.949 & 0.343 \\
\hline Soluble Ractive Phosphorus Load & -1.805 & 0.071 & -1.492 & 0.136 & -0.617 & 0.537 & -2.357 & 0.018 & -2.051 & 0.040 & -0.184 & 0.854 \\
\hline
\end{tabular}

